



\section{De economische en ecologische effecten van inrichtingsvarianten voor de Noordzee tot $2040 / 2050$}

Roebeling, P.C., W.J. Strietman, R.H. Jongbloed, J.E. Tamis, K. Hamon, A. Eweg, S. van den Burg en S. Reinhard 
Roebeling, P.C., W.J. Strietman, R.H. Jongbloed, J.E. Tamis, K. Hamon, A. Eweg, S. van den Burg en S. Reinhard, 2021. De economische en ecologische effecten van inrichtingsvarianten voor de Noordzee tot 2040/2050. Wageningen, Wageningen Economic Research, Rapport 2021-063. 54 blz.; 9 fig.; 27 tab.; 24 ref.

In deze verkenning wordt een indicatieve economische en ecologische vertaling gemaakt van de effecten van vier verschillende ruimtelijke inrichtingsvarianten op de Noordzee gebruiksfuncties. Hierbij wordt voor elke inrichtingsvariant de effecten waar mogelijk kwantitatief doorgerekend en waar dat niet mogelijk is kwalitatief beoordeeld voor het referentiejaar 2017 en de jaren 2040/2050. De economische effecten worden hierbij berekend in termen van de jaarlijkse directe en indirecte productiewaarde, toegevoegde waarde en werkgelegenheid (fte). De ecologische effecten worden hierbij weergegeven in termen van risico voor soortgroepen (zeevogels, zeehonden, bruinvis en andere walvisachtigen, vleermuizen, vissen en rifbouwende soorten) en cumulatieve impacts voor ecosysteem componenten (vogels, vissen, zeezoogdieren en habitats).

In this report, indicative insight is provided into the economic and ecological effects of four future spatial scenarios on the North Sea usage functions. For each of these scenarios, the annual effects on the various usage functions on the Dutch part of the North Sea are calculated or qualitatively described for the years 2017 and 2040/2050. The economic effects are calculated in terms of the annual direct and indirect production value, added value and employment (FTE). The ecological effects are expressed in terms of risk for species groups (seabirds, seals, porpoises and other cetaceans, bats, fish and reef-building species) and cumulative impacts for ecosystem components (birds, fish, marine mammals and habitats).

Trefwoorden: Noordzee, Noordzeebeleid, economische activiteiten, toekomstscenario's, visserij, windenergie op zee

Dit rapport is gratis te downloaden op https://doi.org/10.18174/548296 of op www. wur. nl/economicresearch (onder Wageningen Economic Research publicaties).

(C) 2021 Wageningen Economic Research

Postbus 29703, 2502 LS Den Haag, T 07033583 30, E communications.ssg@wur.nl, www.wur.nl/economic-research. Wageningen Economic Research is onderdeel van Wageningen University \& Research.

\section{(cc) BY-NC}

Dit werk valt onder een Creative Commons Naamsvermelding-Niet Commercieel 4.0 Internationaallicentie.

(C) Wageningen Economic Research, onderdeel van Stichting Wageningen Research, 2021 De gebruiker mag het werk kopiëren, verspreiden en doorgeven en afgeleide werken maken. Materiaal van derden waarvan in het werk gebruik is gemaakt en waarop intellectuele eigendomsrechten berusten, mogen niet zonder voorafgaande toestemming van derden gebruikt worden. De gebruiker dient bij het werk de door de maker of de licentiegever aangegeven naam te vermelden, maar niet zodanig dat de indruk gewekt wordt dat zij daarmee instemmen met het werk van de gebruiker of het gebruik van het werk. De gebruiker mag het werk niet voor commerciële doeleinden gebruiken.

Wageningen Economic Research aanvaardt geen aansprakelijkheid voor eventuele schade voortvloeiend uit het gebruik van de resultaten van dit onderzoek of de toepassing van de adviezen.

Wageningen Economic Research is ISO 9001:2015 gecertificeerd. 


\section{Inhoud}

$\begin{array}{ll}\text { Woord vooraf } & 5\end{array}$

Samenvatting $\quad 6$

S.1 Belangrijkste uitkomsten $\quad 6$

$\begin{array}{ll}\text { S.2 Methode } & 7\end{array}$

Summary $\quad 9$

S.1 Key findings $\quad 9$

S.2 Method 10

1

$\begin{array}{ll}\text { Inleiding } & 12\end{array}$

1.1 Aanleiding $\quad 12$

1.2 Doelstelling $\quad 12$

2

Methodes, aannames en bronnen $\quad 14$

$\begin{array}{lll}2.1 & \text { Economisch effecten analyse } & 14\end{array}$

2.1.1 Inleiding 14

2.1.2 Algemene methode berekening economische effecten $\quad 15$

2.1.3 Specifieke methode berekening visserij effecten 16

$\begin{array}{ll}2.1 .4 \text { Bronnen } & 18\end{array}$

2.2 Natuur/biodiversiteit effectenanalyse $\quad 22$

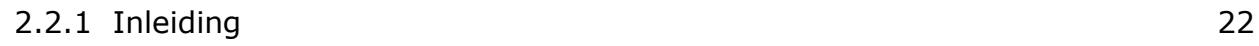

$\begin{array}{ll}2.2 .2 \text { Methode } & 22\end{array}$

$\begin{array}{ll}2.2 .3 \text { Bronnen } & 23\end{array}$

3 Wind-op-zee zoekgebieden en inrichtingsvarianten $\quad 25$

3.1 Kenmerken wind-op-zee zoekgebieden $\quad 25$

$\begin{array}{lll}3.2 & \text { Definitie inrichtingsvarianten } & 28\end{array}$

4

Resultaten $\quad 30$

4.1 Wind-op-zee zoekgebieden $\quad 30$

4.1.1 Economisch effecten $\quad 30$

$\begin{array}{ll}4.1 .2 \text { Natuur/biodiversiteit effecten } & 33\end{array}$

4.2 Inrichtingsvarianten 36

4.2.1 Economisch effecten $\quad 36$

4.2.2 Natuur/biodiversiteit effecten 44

$5 \quad$ Discussie, conclusies en aanbevelingen $\quad 48$

$\begin{array}{lll}5.1 & \text { Discussie } & 48\end{array}$

$\begin{array}{ll}\text { 5.1.1 Wind-op-zee zoekgebieden } & 48\end{array}$

$\begin{array}{ll}5.1 .2 & \text { Inrichtingsvarianten }\end{array}$

$\begin{array}{lll}5.2 & \text { Conclusies } & 49\end{array}$

$\begin{array}{ll}5.3 & \text { Aanbevelingen }\end{array}$

$\begin{array}{ll}\text { Referenties } & \mathbf{5 2}\end{array}$ 



\section{Woord vooraf}

De Rijksoverheid is momenteel bezig met het opstellen van het Programma Noordzee 2022-2027. Daarvoor is een uitgebreid participatieproces in gang gezet dat moet leiden tot een set van afspraken voor de inrichting van de Noordzee voor de lange termijn (2040/2050). Gedurende de periode februari tot en met juni 2020 vond er vanuit de overheid een interactief proces van joint-fact-finding met belanghebbenden plaats, waarin verschillende varianten voor de inrichting van de Noordzee op iteratieve wijze werden gecreëerd en geëvalueerd.

Om deze discussies te ondersteunen, bestond er behoefte aan inzicht in de mogelijke voor- en nadelen van inrichtingsvarianten van de Noordzee voor de verschillende stakeholders. Als bijdrage aan deze discussie over de toekomstige inrichting van de Noordzee, heeft het ministerie van Infrastructuur \& Waterstaat aan Wageningen Economic Research en Wageningen Marine Research gevraagd een zogenaamde Kentallen Analyse uit te voeren. Deze analyse heeft als doel om een inschatting te geven van de orde groottes van de effecten, op economisch en ecologisch gebied, van verschillende varianten voor de toekomstige (ruimtelijke) inrichting van het Nederlandse deel van de Noordzee. Het idee was dat op basis van dit inzicht in de voor- en nadelen van de verschillende varianten, er een keuze zou kunnen worden gemaakt voor een 'voorkeursvariant'.

Dit rapport geeft inzicht in de economische en natuur/biodiversiteit effecten voor de startsituatie (2017) en de toekomst varianten (2040/2050) voor de inrichting van de Noordzee berekend aan de hand van economische (zoals productiewaarde, toegevoegde waarde en werkgelegenheid) en ecosysteem (zoals ecosysteem componenten en soortgroepen) indicatoren. De economische effecten zijn gebaseerd op sector analyse en data, en de natuur/biodiversiteit effecten zijn gebaseerd op cumulatieve effecten analyse en expert opinion-methode. Hoewel er op basis van deze resultaten noch WOZ-zoekgebieden noch varianten zijn aan te wijzen die het duidelijk beter doen, heeft deze studie een belangrijke bijdrage geleverd aan de gesubstantieerde discussie rond de voor- en nadelen van inrichtingsvarianten van de Noordzee voor de verschillende stakeholders.

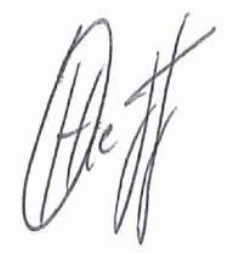

Ir. O. (Olaf) Hietbrink

Business Unit Manager Wageningen Economic Research

Wageningen University \& Research 


\section{Samenvatting}

\section{S.1 Belangrijkste uitkomsten}

- Acht gebieden zijn geïdentificeerd als mogelijke wind-op-zee (WOZ) zoekgebieden, met name (zie Figuur 3.1 en Tabel 3.1): op de grens met Norfolk Boreas (WOZ1), ten noorden van IJmuiden-ver (WOZ2), ten noordwesten van IJmuiden-ver (WOZ3), Defensie oefengebied ten noorden van de Wadden (WOZ4), driehoek op grens met Duitsland (WOZ5), gebied ten noorden van Friese Front (WOZ6), ten oosten van Klaverbank (WOZ7) en ten noordwesten van Texel (WOZ8).

- Windmolenpark exploitatie is het meest efficiënt in, respectievelijk, wind-op-zee zoekgebied WOZ3, WOZ5, WOZ4 en WOZ6; windmolenparkexploitatie is het minst efficiënt in WOZ7 (zie Tabel 4.1). De efficiëntie is, met name, afhankelijk van de bouwkosten, het rendement van de windmolenparken en de aanlandingskosten (kabels). Windmolenpark bouw is het meest lucratief in, respectievelijk, windop-zee zoekgebied WOZ7, WOZ6 en WOZ1; het laagste in WOZ4 (zie Tabel 4.2). In tegenstelling tot windmolenpark exploitatie, leiden juist hogere bouwkosten tot een hogere toegevoegde waarde in windmolenpark bouw. De rentabiliteit van windmolenpark exploitatie is, echter, bepalend voor het al dan niet exploiteren van windmolenparken. Visserij ondervindt de grootste negatieve consequenties in, respectievelijk, WOZ6, WOZ1 en WOZ5 (zie Tabel 4.6). Met name boomkor-/sumwing/pulsvisserij en bordentrawls/twinrig ondervinden de grootste negatieve consequenties.

- Expertinschattingen per soortgroep (zie Tabel 4.7) geven aan dat voor zeevogels de minste effecten worden verwacht voor WOZ1, WOZ2, WOZ6 en WOZ8, en de meeste voor WOZ3, WOZ5 en WOZ7. Voor vissen is de inschatting neutraal voor alle gebieden. Voor zeehonden zijn de potentiële effecten groot voor (bijna) alle WOZ-zoekgebieden (voor WOZ3, WOZ6 en WOZ7 zijn de effecten onduidelijk). Voor bruinvis worden de minste effecten verwacht voor WOZ1, en de meeste effecten voor WOZ2, WOZ3, WOZ4 en WOZ8 (voor de WOZ5, WOZ6 en WOZ7 zijn de effecten onduidelijk). Voor vleermuizen worden de meeste effecten verwacht voor WOZ1 en WOZ2 (voor de overige gebieden zijn effecten onduidelijk. Tot slot, voor benthos worden de meeste kansen verwacht voor WOZ4, en de minste kansen voor WOZ7.

- Vier varianten voor de inrichting van de Noordzee zijn op iteratieve wijze gedefinieerde, welke te onderscheiden zijn in globale locatie van de WOZ-zoekgebieden (zie Tabel 3.2 en Tabel 3.3). Dit zijn WOZ-zoekgebieden meer in het zuiden (Combinatie Zuid), een mix van energiecluster in zuiden en noorden (Mix Energiehubs), WOZ-zoekgebieden meer in het noorden (Combinatie Noord) en WOZzoekgebieden met kleinere afstand tot de kust (Dichtbij Energievraag).

- De varianten worden gekenmerkt door een vrijwel volledige afname in olie- en gaswinning, een 39\% toename in scheepvaart, gelijkblijvende scheepvaartveiligheid, een groei in windmolenparken van $11,5 \mathrm{GW}$ tot 2030 en nog eens 28 GW tot 2040/2050, een opschaling van aqua-/maricultuur tot $400 \mathrm{~km}^{2}$ (medegebruik in windmolenparken), een $60 \%$ toename in zandwinning, een uitbreiding van natuurgebieden volgens het Noordzee-akkoord (versie april 2020) en een toe-/afname in visgebied afhankelijk van de ontwikkelingen in andere gebruiksfuncties.

- De varianten laten een grote verschuiving zien in het relatief economische belang van de verschillende gebruiksfuncties tussen 2017 en 2040/2050. Windmolenpark exploitatie, windmolenpark bouw en aqua-/maricultuur zouden gebruiksfuncties met een relatief groot economisch belang worden, scheepvaart en zandwinning behouden hun economisch belang, visserij laat een afname in economisch belang zien, en olie- en gaswinning zou een gebruiksfunctie met geen economische waarde van betekenis worden. Met betrekking tot werkgelegenheid zien we een gediversifieerd beeld ontstaan in de varianten, waarbij meerdere gebruiksfuncties substantieel bijdragen aan de werkgelegenheid op het NCP van Noordzee.

- De impact van de varianten op vogels, vissen, zeezoogdieren en habitats, laat zien dat voor vogels en zeezoogdieren de totale impact is toegenomen terwijl voor vissen en habitats de totale impact is afgenomen. De toegenomen impact op vogels en zeezoogdieren is, met name, een gevolg van de ontwikkeling van windenergie. De afgenomen impact op vissen en habitats is, met name, 
gerelateerd aan de afname in visserij en toenamen in habitat oppervlakte als gevolg van de sluiting voor gebruiksfuncties van windmolenparken en natuurgebieden.

- De verschillen in economische en natuur/biodiversiteit effecten tussen de varianten zijn relatief klein, hetgeen het gevolg is van de kleine verschillen tussen de varianten - i.e. slechts variatie in de locatie van WOZ-zoekgebieden. Voor de economische effecten betekent dit dat er relatief kleine (ten opzichte van totale waardes van alle gebruiksfuncties) verschillen in bouwkosten, rendementsverschillen en aanlandingskosten (kabels) zijn van de WOZ-zoekgebieden die samen $28 \mathrm{GW}$ vormen. De economische analyse (zie S.2) duidt op een lichte voorkeur voor Variant 2 (Mix Energiehubs). Voor de natuur/biodiversiteit effecten betekent dit dat er nauwelijks verschillen zijn in oppervlaktes van de gebruiksfuncties op het NCP van de Noordzee, terwijl de Cumulatieve Effecten Analyse (zie S.2) in zijn huidige vorm wel de oppervlakte maar niet de locatie impacts van gebruiksfuncties kan duiden. De natuur Expert opinion analyse (zie S.2) duidt op een lichte voorkeur voor Variant 2 (Mix Energiehubs).

- Op basis van deze resultaten zijn er noch WOZ-zoekgebieden noch varianten aan te wijzen die het duidelijk beter doen. Voor alle WOZ-zoekgebieden en varianten lijken er geen win-win kandidaten te zijn - i.e. iedere van de onderzochte keuzemogelijkheden hebben negatieve consequenties, zij het voor de economie, de werkgelegenheid of de natuur. Voor alle varianten geldt dat ze, in vergelijking tot de huidige situatie, leiden tot een grote verschuiving in het relatief economische belang van de verschillende gebruiksfuncties alsmede een grote impact op de natuur en biodiversiteit (vogels en zeezoogdieren). Er bestaat onvoldoende kennis om de impact op deze soortgroepen eenduidig te kunnen kwantificeren per WOZ zoekgebied. Aan de hand van de expert inschattingen voor alle soortgroepen tezamen, inclusief kansen voor rifbouwende soorten, is er wel een rangorde op volgorde van afnemende geschiktheid van WOZ-zoekgebieden en varianten voor natuur en biodiversiteit aan te geven, maar de betrouwbaarheid van dat resultaat is beperkt vanwege belangrijke kennislacunes.

\section{S.2 Methode}

- Op basis van de methodologie ontwikkeld in Strietman et al. (2019) en Jongbloed et al. (2019) worden, respectievelijk, de economische en natuur/biodiversiteit effecten voor de startsituatie (2017) en de toekomst varianten (2040/2050) voor de inrichting van de Noordzee berekend aan de hand van economische (zoals productiewaarde, toegevoegde waarde en werkgelegenheid) en ecosysteem (zoals ecosysteem componenten en soortgroepen) indicatoren.

- Om een indicatie te krijgen van de richting van de economische effecten van de verschillende ruimtelijke inrichtingsvarianten, wordt gebruikgemaakt van sector analyse (Strietman et al., 2019) en, specifiek voor visserij, de VMS-mapping methode (Hintzen et al., 2012).

- In de sectoranalyse worden de huidige economische waarden (2017) van de sectoren bepaald, worden de groeifactoren voor de toekomst varianten (2040/2050) per sector geschat en worden de toekomstige economische waarden (2040/2050) van de sectoren berekend.

- In de VMS-mapping methode wordt de huidige (2017) economische waarde (productiewaarde, toegevoegde waarde en werkgelegenheid) berekend voor de gebieden die nog overblijven voor de visserij indien er sluitingen van gebieden plaatsvinden voor windmolenparken en natuurgebieden zoals die in de inrichtingsvarianten geprojecteerd zijn (2040/2050).

- De belangrijkste gegevensbronnen voor deze studie betreffen de Wageningen Economic Researchpublicatie De economische effecten van twee toekomstscenario's voor de Noordzee (Strietman et al, 2019), de PBL-publicatie De toekomst van de Noordzee - De Noordzee in 2030 en 2050: een scenariostudie ( $\mathrm{PBL}, 2018$ ) en het bijbehorende achtergronddocument ( $\mathrm{PBL}, 2019)$, de CBSpublicatie Economic description of the Dutch North Sea and Coast: 2005, 2010, 2014 (CBS, 2016), CBS (Statline-) gegevens uit de Nationale Rekeningen, de Ecorys-publicatie De Nederlandse Maritieme Cluster (Ecorys, 2018), de PWC-publicatie De economische bijdrage van windenergie op zee (PWC, 2018), de BLIX-publicatie Study into levelized cost of energy of seven new wind zones and IJmuiden Ver (BLIX, 2020) en sectordata over de Nederlandse visserij (beheerd door Wageningen Economic Research). 
- Om een indicatie te krijgen van de richting van de ecologische effecten van de verschillende ruimtelijke inrichtingsvarianten, wordt gebruikgemaakt van de Cumulatieve Effecten Analyse (CEA; Jongbloed et al., 2019). Om een indicatie te krijgen van de mogelijke natuur/biodiversiteit effecten van windenergie productie in WOZ zoekgebieden, wordt gebruikgemaakt van de Expert opinionmethode (Jongbloed et al., 2020).

- In de CEA wordt het verschil in impact van gebruiksfuncties op de voornaamste ecosysteem componenten (voor vis, vogels, zeezoogdieren en habitats) berekend tussen de niet beïnvloede situatie, de huidige situatie (2017) en de (hypothetische) toekomstige situaties (2040/2050). Daarmee wordt inzichtelijk gemaakt hoe de ecologische effecten van verschillende beleidsmaatregelen zich tot elkaar verhouden.

- In de Expert opinion-methode zijn, aan de hand van een gerichte vragenlijst, zeven WMR-experts benaderd hun inschatting en mening te geven over wat er wel mogelijk is en wat er niet mogelijk is met betrekking tot verschillen in de waarde voor soorten/soortgroepen (zeevogels, zeehonden, bruinvis en andere walvisachtigen, vleermuizen, vissen en rifbouwende soorten) tussen de acht WOZ-zoekgebieden op het Nederlands Continentaal Plat (NCP).

- De belangrijkste gegevensbronnen voor deze studie betreffen de Wageningen Marine Researchpublicatie Natuur Verkenning voor de Noordzee: Voorbeeld uitwerking van een Noordzee bijdrage aan de Natuurverkenningen (Jongbloed et al., 2019), de database van het EU project Aquacross (www.aquacross.eu; Borgwardt et al., 2019) en de Wageningen Marine Research-studie Expert inschatting van nieuwe windparkzoekgebieden op de Noordzee voor verschillende soortgroepen (Jongbloed et al., 2020). 


\section{Summary}

\section{S.1 Key findings}

- Eight areas have been identified as possible search areas for offshore wind (WOZ), in particular (see Figure 3.1 and Table 3.1: on the border with Norfolk Boreas (WOZ1), north of IJmuiden Ver (WOZ2), northwest of IJmuiden Ver (WOZ3), the Dutch Defence training area north of the Wadden islands (WOZ4), the triangle on the border with Germany (WOZ5), the area north of Friese Front offshore nature conservation area (WOZ6), east of the Cleaver Bank (WOZ7) and northwest of the island of Texel (WOZ8).

- Wind farm operation is most efficient in, respectively, the offshore search areas WOZ3, WOZ5, WOZ4 and WOZ6, and least efficient in WOZ7 (see Table 4.1). This efficiency depends in particular on the construction costs, the energy yield of the wind farms and the landing costs (cables). Wind farm construction is most lucrative in, respectively, offshore search areas WOZ7, WOZ6 and WOZ1 and lowest in WOZ4 (see Table 4.2). In contrast to wind farm operation, higher construction costs lead to higher value-added in wind farm construction. The profitability of wind farm operation is, however, a decisive factor in considerations as to whether or not to operate a wind farm. Fishing experiences the greatest negative consequences in, respectively, WOZ6, WOZ1 and WOZ5 (see Table 4.6). In particular, beam trawling, sumwing, pulse fishing, otter trawling and twin trawling suffer the greatest negative consequences.

- Expert assessments per species group (see Table 4.7) indicate that, for seabirds, the lowest number of effects is expected for WOZ1, WOZ2, WOZ6 and WOZ8 and the highest for WOZ3, WOZ5 and WOZ7. For fish, the assessment is neutral for all areas. For seals, the potential effects are considerable for almost all WOZ search areas (the effects are unclear for WOZ3, WOZ6 and WOZ7). For harbour porpoise, the lowest number of effects is expected for WOZ1 and the highest for WOZ2, WOZ3, WOZ4 and WOZ8 (the effects are unclear for WOZ5, WOZ6 and WOZ7). For bats, most effects are expected for WOZ1 and WOZ2 (effects are unclear for the other areas). Finally, for benthos, the greatest number of opportunities is expected for WOZ4 and the lowest for WOZ7.

- Four variants of spatial planning in the North Sea were defined in an iterative manner, and these differ in terms of the global location of the WOZ search areas (see Table 3.2 and Table 3.3). These are WOZ search areas located more in the south (Combinatie Zuid/Combination South), a mix of energy cluster in the south and north (Mix Energiehubs/Mix Energy Hubs), WOZ search areas located more in the north (Combinatie Noord/Combination North) and WOZ search areas with a shorter distance to the coast (Dichtbij Energievraag/Close to Energy Demand).

- The variants are characterised by an almost complete reduction in oil \& gas production, a $39 \%$ increase in shipping, no change in shipping safety, an increase in wind farms of $11.5 \mathrm{GW}$ until 2030 and another approx. $28 \mathrm{GW}$ until 2040/2050, an upscaling of aquaculture and mariculture to 400 $\mathrm{km}^{2}$ (co-use in wind farms), a $60 \%$ increase in sand mining, an expansion of nature conservation areas according to the North Sea Agreement (April 2020 version) and an increase or decrease in fishing area depending on developments in these other uses.

- The variants show a major shift in the relative economic importance of the different uses between 2017 and 2040/2050. Wind farm operation, wind farm construction and aquaculture-mariculture would become uses of relatively high economic importance; shipping and sand mining would retain their economic importance; fishing would register a decline in economic importance, and oil \& gas extraction would become a use with no significant economic value. The variants present a diversified picture in terms of jobs, with several uses contributing substantially to job creation on the Dutch continental shelf (NCP) of the North Sea

- In terms of the variants' impact on birds, fish, marine mammals and habitats, the total impact on birds and marine mammals has increased, while the total impact on fish and habitats has decreased. The increased impact on birds and marine mammals is, in particular, a consequence of the development of wind energy. The decreased impact on fish and habitats is, in particular, related to 
the decrease in fishing and increase in habitat area as a result of areas being allocated for use as wind farms and nature reserves.

- The differences in economic and nature-biodiversity effects between the variants are relatively small, which is due to the minor differences between the variants, i.e. there is only variation in the location of WOZ search areas. In terms of the economic effects, this means that there are relatively small (compared with the total values of all uses) differences in construction costs, energy yields and landing costs (cables) of the WOZ search areas that together form $28 \mathrm{GW}$. The economic analysis (see S.2) suggests a slight preference for Variant 2 (Mix Energy Hubs). In terms of the effects on nature and biodiversity, this means that there are hardly any differences in the surface areas of the uses on the NCP of the North Sea, while the Cumulative Effects Analysis (see S.2) - in its current form - can indicate the surface area but not the location impacts of uses. The nature Expert opinion analysis (see S.2) indicates a slight preference for Variant 2 (Mix Energy Hubs).

- On the basis of these results, it is not possible to identify either WOZ search areas or variants with a clearly superior performance. There seem to be no win-win candidates in any of the WOZ search areas and variants, i.e. each of the options investigated has negative consequences, whether for the economy, jobs or nature. Compared with the current situation, all variants lead to a major shift in the relative economic importance of the various uses and a major impact on nature and biodiversity (birds and marine mammals). There is insufficient knowledge to unambiguously quantify the impact on these species groups for each WOZ search area. Based on the expert assessments for all species groups together, including opportunities for reef-building species, it is possible to rank the declining suitability of WOZ search areas and variants for nature and biodiversity, but the reliability of that result is limited due to significant gaps in knowledge.

\section{S.2 Method}

- Based on the methodology developed in Strietman et al. (2019) and Jongbloed et al. (2019), the economic and nature-biodiversity effects are calculated for the reference situation (2017) and the future variants (2040/2050) of the North Sea spatial planning respectively on the basis of economic indicators (such as production value, value-added and jobs) and ecosystem indicators (such as ecosystem components and species groups).

- Sector analysis (Strietman et al., 2019) and, specifically for fisheries, the VMS mapping method (Hintzen et al., 2012) are used to obtain an indication of how the economic effects may develop in the different spatial planning variants.

- The sector analysis determines the current economic values (2017) of the sectors, estimates the growth factors for the future variants (2040/2050) per sector and calculates the sectors' future economic values (2040/2050).

- The VMS mapping method calculates the current (2017) economic value (production value, valueadded and jobs) for the areas remaining for fishing if areas are closed in order to create wind farms and nature reserves as planned in the spatial planning variants (2040/2050).

- The main data sources for this study are the Wageningen Economic Research publication De economische effecten van twee toekomstscenario's voor de Noordzee (Strietman et al, 2019), the PBL publication De toekomst van de Noordzee - De Noordzee in 2030 en 2050: een scenariostudie (PBL, 2018) and the accompanying background document (PBL, 2019), the CBS publication Economic description of the Dutch North Sea and Coast: 2005, 2010, 2014 (Statistics Netherlands, 2016), Statistics Netherlands (Statline) data from the Netherlands National Accounts, the Ecorys publication De Nederlandse Maritieme Cluster (Ecorys, 2018), the PWC publication De economische bijdrage van windenergie op zee (PWC, 2018), the BLIX publication Study into levelized cost of energy of seven new wind zones and IJmuiden Ver (BLIX, 2020) and sector data on Dutch fisheries (managed by Wageningen Economic Research).

- The Cumulative Effects Analysis (CEA; Jongbloed et al., 2019) is used to obtain an indication of how the ecological effects may develop in the different spatial planning variants. The Expert Opinion method is used (Jongbloed et al., 2020) to obtain an indication of the possible effects on nature and biodiversity associated with wind energy production in the WOZ search areas. 
- The CEA calculates the difference in impact of the uses on the main ecosystem components (for fish, birds, marine mammals and habitats) between the unaffected situation, the current situation (2017) and the (hypothetical) future situations (2040/2050). This provides an insight into the ecological effects of different policies.

- The Expert opinion method targeted seven WMR experts, who were asked to give their assessment and opinion on what is and what is not possible regarding differences in value for species or species groups (seabirds, seals, porpoises and other cetaceans, bats, fish and reef-building species) between the eight WOZ search areas on the Dutch Continental Shelf (NCP).

- The main data sources for this study are the Wageningen Marine Research publication Natuur Verkenning voor de Noordzee: Voorbeeld uitwerking van een Noordzee bijdrage aan de Natuurverkenningen (Jongbloed et al., 2019), the database of the EU project Aquacross (www.aquacross.eu; Borgwardt et al., 2019) and the Wageningen Marine Research study Expert inschatting van nieuwe windparkzoekgebieden op de Noordzee voor verschillende soortgroepen (Jongbloed et al., 2020). 


\section{$1 \quad$ Inleiding}

\section{$1.1 \quad$ Aanleiding}

De Rijksoverheid is momenteel bezig met het opstellen van het Programma Noordzee 2022-2027. Daarvoor is een uitgebreid participatieproces in gang gezet dat moet leiden tot een set van afspraken voor de inrichting van de Noordzee voor de lange termijn (2040/2050). Gedurende de periode februari tot en met juni 2020 vond er vanuit de overheid een interactief proces van joint-fact-finding met belanghebbenden plaats, waarin verschillende varianten voor de inrichting van de Noordzee op iteratieve wijze werden gecreëerd en geëvalueerd.

Om deze discussies te ondersteunen, bestond er behoefte aan inzicht in de mogelijke voor- en nadelen van inrichtingsvarianten van de Noordzee voor de verschillende stakeholders. Gezien de korte doorlooptijd van deze discussies, was er vanuit het ministerie van Infrastructuur \& Waterstaat behoefte aan snelle berekeningen die op basis van de best beschikbare cijfers, globale inschattingen gaven van de orde groottes van de mogelijke voor- en nadelen - waaronder de mogelijke kosten en baten voor verschillende stakeholders op en rond de Noordzee. Het idee was dat op basis van dit inzicht in de voor- en nadelen van de verschillende varianten, er een keuze zou kunnen worden gemaakt voor een 'voorkeursvariant'.

Als bijdrage aan de discussie over de toekomstige inrichting van de Noordzee, heeft het ministerie van Infrastructuur \& Waterstaat aan Wageningen Economic Research en Wageningen Marine Research gevraagd een zogenaamde Kentallen Analyse uit te voeren. Deze analyse heeft als doel om een inschatting te geven van de orde groottes van de effecten, op economisch en ecologisch gebied, van verschillende varianten voor de toekomstige (ruimtelijke) inrichting van het Nederlandse deel van de Noordzee.

Met een dergelijke analyse kunnen de verwachte effecten niet exact in kaart gebracht worden, maar wel de richting van de te verwachten effecten. Daarmee dus ook het relatieve belang van de gebieden die in de inrichtingsvarianten en het Noordzee Akkoord benoemd staan als gebieden waar ruimte gegeven wordt aan de verschillende gebruiksfuncties op zee, waaronder zoekgebieden voor windenergie of natuur op zee. In dit rapport beschrijven we de resultaten van de analyse.

\subsection{Doelstelling}

Het overkoepelend doel van deze studie is, derhalve, een Kentallen Analyse uit te voeren ter inschatting van de orde groottes van de economische en ecologische effecten van de, op iteratieve wijze gedefinieerde, varianten voor de inrichting van het Nederlandse deel van de Noordzee in 2040/2050. Dit teneinde het interactieve en iteratieve proces voor het opstellen van het Programma Noordzee 2022-2027 te ondersteunen.

Dit rapport geeft een beschrijving van de methode, aannames en bronnen die ten grondslag liggen aan de Kentallen Analyse alsmede de resultaten van de economische (in termen van productiewaarde, toegevoegde waarde en werkgelegenheid) en ecologische (in termen van risico voor soortgroepen en cumulatieve impacts voor ecosysteem componenten) effecten van de varianten voor de inrichting van het Nederlandse deel van de Noordzee in 2040/2050. Economische effecten worden berekend voor de belangrijkste gebruiksfuncties (olie- en gaswinning, scheepvaart, windenergie, visserij, aqua/maricultuur en zandwinning); ecologische effecten worden berekend voor soortgroepen (zeevogels, zeehonden, bruinvis en andere walvisachtigen, vleermuizen, vissen en rifbouwende soorten) en ecosysteem componenten (vogels, vissen, zeezoogdieren en habitats). 
Deze studie is uitgevoerd op basis van bestaande (economische en ecologische) gegevens en aannames (d.d. juni 2020). Gezien de beschikbare informatie en de inherente onzekerheid rond toekomstvarianten (en zeker in een dermate turbulente (beleids-) omgeving als de Noordzee), dienen de in deze studie gepresenteerde getallen en berekeningen niet als voorspellingen te worden gezien maar als aanduiding van orde van groottes, relatieve verschillen en verwachte ontwikkelingen.

In dit rapport bespreken we de methodes, aannames en bronnen (Hoofdstuk 2), definiëren we de wind-op-zee (WOZ-)zoekgebieden en resulterende varianten (Hoofdstuk 3), presenteren we de resultaten voor de WOZ-zoekgebieden en varianten (Hoofdstuk 4) en, tot slot, bediscussiëren we de resultaten, trekken we conclusies en geven we aanbevelingen (Hoofdstuk 5). 


\section{Methodes, aannames en bronnen}

Op basis van de methodologie ontwikkeld in Strietman et al. (2019; zie Sectie 2.1) en Jongbloed et al. (2019; zie Sectie 2.2) worden, respectievelijk, de economische en natuur/biodiversiteit effecten voor de startsituatie (2017) en de toekomst varianten (2040/2050) voor de inrichting van de Noordzee berekend aan de hand van economische (zoals productiewaarde, toegevoegde waarde en werkgelegenheid) en ecosysteem (zoals ecosysteem componenten en soortgroepen) indicatoren.

\subsection{Economisch effecten analyse}

\subsubsection{Inleiding}

Om een indicatie te krijgen van de economische effecten van de verschillende varianten voor de inrichting van de Noordzee, wordt gebruikgemaakt van een methodiek waarbij de economische effecten van verschillende ruimtelijke varianten voor de inrichting van de Noordzee in kaart gebracht worden voor de jaren 2017 (referentie jaar) en 2040/2050 (toekomstjaar). Hieronder lichten wij deze methodiek nader toe en gaan nader in op hoe wij die toepassen in deze studie.

Voor het doorrekenen van de economische effecten van de verschillende varianten voor de inrichting van de Noordzee, hanteren we een aantal algemene uitgangspunten en aannames (hier beschreven) alsmede een aantal gebruiksfunctie specifieke uitgangspunten en aannames (zie Sectie 2.1.4). De algemene uitgangspunten en aannames zijn als volgt:

- Voor deze studie worden de jaarlijkse economische effecten van verschillende ruimtelijke varianten voor de inrichting van de Noordzee (met gebruiksfuncties) in kaart gebracht voor de ijkjaren 2017 en $2040 / 2050$ op basis van de ruimtelijke inrichtingsvarianten. Alle monetaire waardes zijn daarbij in euro's voor het jaar 2017.

- De Noordzee gebruiksfuncties betreffen olie- en gaswinning, scheepvaart, windenergie, visserij, aqua-/maricultuur en zandwinning.

- Deze gebruiksfuncties zijn allen gelokaliseerd op het Nederlands Continentaal Plat (NCP). Het NCP omvat de Noordzee, maar niet de Waddenzee, Oosterschelde en Westerschelde.

- Binnen het NCP zoomen we voor het doorrekenen van de effecten van de verschillende varianten, in op verschillende WOZ-zoekgebieden in relatie tot windenergie, visserij en natuur. Daarmee is inzichtelijk te maken hoe de verschillende WOZ-zoekgebieden zich tot elkaar verhouden qua economische en natuur waardes.

- Als indicatoren voor de economische effecten hanteren we de productiewaarde, toegevoegde waarde en de werkgelegenheid ( $\mathrm{fte}$ ) van de Nederlandse economie. Voor deze indicatoren is gekozen omdat de productiewaarde een relatie heeft met de milieudruk, de toegevoegde waarde bijdraagt aan het Bruto Nationaal Product en werkgelegenheid als indicatie gebruikt kan worden voor het sociale belang van een gebruiksfunctie.

- Als het gaat om de economische effecten op de productiewaarde, de toegevoegde waarde en de werkgelegenheid dan bedoelen we daarmee zowel de directe als de indirecte effecten. Waar de directe effecten uitsluitend op het NCP spelen, vinden de indirecte effecten vooral op land plaats. Dit betekent dat we in deze studie zowel de effecten op het NCP als die op land doorrekenen:

- Bij de directe effecten gaat het om de effecten van ruimtelijke inrichtingskeuzes op de productiewaarde, toegevoegde waarde en werkgelegenheid van gebruiksfuncties die op het NCP plaatsvinden.

- Bij de indirecte effecten gaat het om de effecten die ontstaan door de aanvoer van goederen en diensten vanuit Nederland om daarmee de huidige en toekomstige activiteiten binnen de gebruiksfuncties op zee mogelijk te maken. Die goederen en diensten worden grotendeels op land gegenereerd. Denk hierbij bijvoorbeeld aan het produceren van windmolenonderdelen of het leveren van havenfaciliteiten om op de Noordzee windenergie te kunnen produceren. 
- Als bron voor informatie over de indirecte economische effecten is grotendeels gebruikgemaakt van de Maritieme Monitor (Ecorys, 2018). Daarin zijn per gebruiksfunctie op basis van inputoutputmodellen de indirecte effecten van verschillende maritieme sectoren (gebruiksfuncties) bepaald. Aangezien in die publicatie geen verdere informatie vermeld staat over welke sectoren in welke mate verantwoordelijk zijn voor deze indirecte effecten, is het (waar wij van deze bron gebruikmaken) niet mogelijk om die in deze studie specifiek te benoemen. Waar we in deze studie gebruik maken van andere bronnen om de indirecte effecten te bepalen, en waar die inzicht geven in de mate waarin welke sectoren hierbij betrokken zijn, geven we dat aan.

- In tegenstelling tot de indirecte effecten die ontstaan als gevolg van de aanvoer van goederen en diensten voor gebruiksfuncties op zee, nemen we de indirecte effecten die ontstaan als gevolg van afvoer/verwerking van goederen en diensten vanuit gebruiksfuncties op zee (bijvoorbeeld de economische effecten van de aanvoer van Noordzeevis op de Nederlandse visafslagen) en substitutie-effecten (bijvoorbeeld de invloed van extra windmolenparken op het rendement van Nederlandse kolencentrales) niet mee. Een dergelijke aanvullende exercitie valt buiten de scope van deze studie vanwege het ontbreken van voldoende (betrouwbare) gegevens en cijfers over dergelijke (complexe) effecten.

Voor deze verkenning vormden de volgende publicaties en gegevens de belangrijkste basis:

- De Wageningen Economic Research-publicatie De economische effecten van twee toekomstscenario's voor de Noordzee (Strietman et al., 2019), waarin voor twee door het PBL opgestelde ruimtelijke toekomstscenario's een vergelijkbare analyse wordt uitgevoerd als voor deze studie.

- De PBL-publicatie De toekomst van de Noordzee - De Noordzee in 2030 en 2050: een scenariostudie (PBL, 2018) en het bijbehorende Achtergronden bij de toekomst van de Noordzee: onderliggende gegevens en aannames (PBL, 2019).

- Sectordata over de Nederlandse visserij (beheerd door Wageningen Economic Research).

- De CBS-publicatie Economic description of the Dutch North Sea and Coast: 2005, 2010, 2014 (CBS, 2016), evenals recentere CBS (Statline-) gegevens uit de Nationale Rekeningen.

- De Ecorys-publicatie De Nederlandse Maritieme Cluster (Ecorys, 2018). De gegevens uit deze bron worden voornamelijk gebruikt om de indirecte effecten te bepalen en in sommige gevallen om de startsituatie te bepalen.

- De PWC-publicatie De economische bijdrage van windenergie op zee (PWC, 2018) en de BLIXpublicatie Study into levelized cost of energy of seven new wind zones and IJmuiden Ver (BLIX, 2020).

Daarnaast is er voor deze studie gebruikgemaakt van aanvullende publicaties, welke in de hoofdstukken van de betreffende gebruiksfuncties benoemd worden. Waar er voor het berekenen van de effecten geen gegevens voorhanden zijn in publicaties, is gebruikgemaakt van expert judgement of is een PM-post toegepast.

\subsubsection{Algemene methode berekening economische effecten}

De berekening van de directe en indirecte economische effecten (productiewaarde, toegevoegde waarde en werkgelegenheid) die we in deze studie per gebruiksfunctie, inrichtingsvariant en WOZzoekgebied doorrekenen, worden in drie stappen uitgevoerd. Hieronder beschrijven we per stap in het proces de uitgevoerde acties.

\section{Stap 1: Berekening startsituatie}

De directe en indirecte waardes vormen de basis voor het calculatiemodel. Hierin wordt per gebruiksfunctie op de Noordzee aangegeven wat in het referentiejaar (2017) de startwaarden zijn voor de productiewaarde (PW), toegevoegde waarde (TW) en werkgelegenheid (Werk). Dit ziet er (met voorbeeldgetallen) uit als in Tabel 2.1. Zie Sectie 2.1.4. voor de berekening van de startwaardes. 
Tabel 2.1 Illustratie calculatiemodel: directe en indirecte productiewaarde (PW), toegevoegde waarde (TW) en werkgelegenheid (Werk) per gebruiksfunctie (GF) in referentiejaar

\begin{tabular}{|c|c|c|c|c|c|c|}
\hline & \multicolumn{3}{|c|}{ Directe effecten } & \multicolumn{3}{|c|}{ Indirecte effecten } \\
\hline & $\begin{array}{c}\text { PW } \\
\text { (in } \mathrm{mln} . \varepsilon \text { ) }\end{array}$ & $\begin{array}{c}\text { TW } \\
\text { (in } \mathrm{mln} . \varepsilon \text { ) }\end{array}$ & $\begin{array}{c}\text { Werk } \\
\text { (in } 1.000 \text { fte) }\end{array}$ & $\begin{array}{c}\text { PW } \\
\text { (in mln. } € \text { ) }\end{array}$ & $\begin{array}{c}\text { TW } \\
\text { (in } \mathrm{mln} . \mathrm{C} \text { ) }\end{array}$ & $\begin{array}{c}\text { Werk } \\
\text { (in } 1.000 \text { fte) }\end{array}$ \\
\hline GF 1 & 5,0 & 2,5 & 200 & 2,0 & 1,3 & 100 \\
\hline GF 2 & $\ldots$ & $\ldots$ & $\ldots$ & $\ldots$ & $\ldots$ & $\ldots$ \\
\hline$\ldots$ & $\ldots$ & $\ldots$ & $\ldots$ & $\ldots$ & $\ldots$ & $\ldots$ \\
\hline GF n & $\ldots$ & $\ldots$ & $\ldots$ & $\ldots$ & $\ldots$ & $\ldots$ \\
\hline
\end{tabular}

Stap 2: Bepaling van de groeifactoren per gebruiksfunctie en per variant in toekomstjaar Een groeifactor is het verschil in omvang van een gebruiksfunctie tussen het referentiejaar (2017) en het toekomst jaar (2040/2050) voor een bepaalde variant. Voorbeeld: wordt er in het toekomstjaar (2040/2050) voor een bepaalde gebruiksfunctie ten opzichte van het referentiejaar (2017) in een bepaalde variant een groei van $10 \%$ verwacht, dan is de groeifactor 1,10 (zie Tabel 2.2). De groeifactoren die in deze studie gehanteerd worden zijn gebaseerd op sector schattingen en publicaties (zie Sectie 2.1.4.) en bijbehorende achtergrondinformatie (locatie, omvang en intensiteit van gebruiksfuncties).

Tabel 2.2 Illustratie calculatiemodel: voorbeeld groeifactoren per gebruiksfunctie (GF) en variant in toekomstjaar

\begin{tabular}{lcccc} 
& Variant 1 & Variant 2 & Variant 3 & Variant \\
GF 1 & 1,10 & 1,15 & 1,05 & 1,20 \\
GF 2 & $\ldots$ & $\ldots$ & $\ldots$ & $\ldots$ \\
\hline$\ldots$ & $\ldots$ & $\ldots$ & $\ldots$ & $\ldots$ \\
\hline GF $n$ & $\ldots$ & $\ldots$ & $\ldots$ & $\ldots$ \\
\hline
\end{tabular}

Stap 3: Berekening economische impact per gebruiksfunctie en per variant in toekomstjaar Om per variant de omvang van de productiewaarde, toegevoegde waarde en werkgelegenheid te berekenen, worden de groeifactoren voor de varianten vermenigvuldigd met de startwaarden van de productiewaarde, toegevoegde waarde en werkgelegenheid in het referentiejaar (2017). Aldus, voor gebruiksfunctie 1 in Variant 1 zou de omvang dus 1,10 maal de omvang in 2017 zijn (zie Tabel 2.3).

Tabel 2.3 Illustratie calculatiemodel: directe en indirecte productiewaarde (PW), toegevoegde waarde (TW) en werkgelegenheid (Werk) per gebruiksfunctie (GF) voor Variant 1 in toekomstjaar

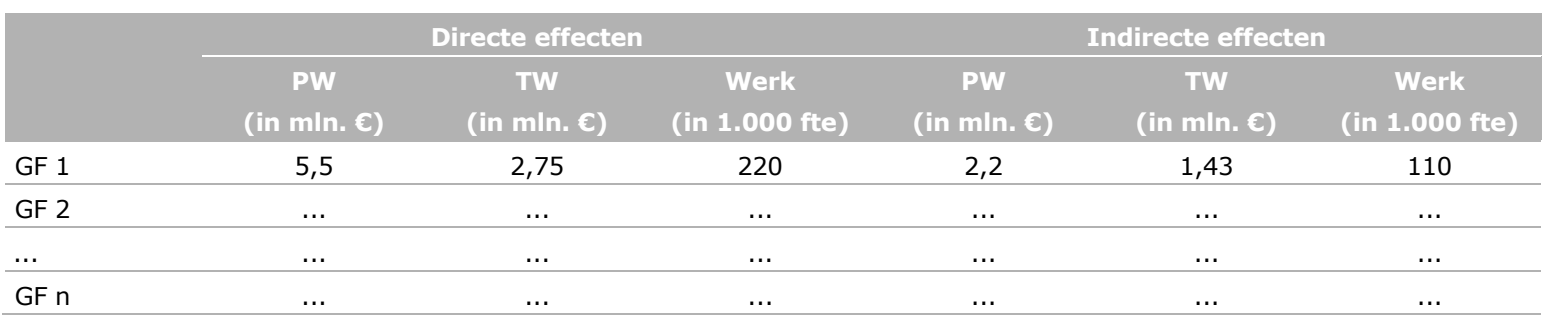

\subsubsection{Specifieke methode berekening visserij effecten}

\subsubsection{Inleiding}

Aangezien de ruimtelijke uitwerking van de varianten in belangrijke mate de waardes van de verschillende types visserij bepaalt, is er voor visserij gekozen voor een aanpak waarbij de huidige economische waarde (productiewaarde, toegevoegde waarde en werkgelegenheid) wordt berekend voor de gebieden die nog overblijven voor de visserij indien er sluitingen van gebieden plaatsvinden 
voor windmolenparken en natuurgebieden zoals die in de inrichtingsvarianten geprojecteerd zijn. Dit wordt per visserijtype berekend.

Deze waardebepaling is geen complete effectberekening voor een toekomstige situatie. Hiervoor zijn twee redenen:

1. Voor een gedegen effectstudie zouden meer aspecten meegenomen dienen te worden dan alleen de waardes en fte van visgebieden. Denk bijvoorbeeld aan de effecten van deze activiteit op zee op de bedrijven en visserijgemeenschappen die direct en indirect afhankelijk zijn van de visserij, bijvoorbeeld visverwerking en transport maar ook de plaatselijke horeca.

2. In de periode 2016-2018 ging het de Nederlandse visserijsector economisch voor de wind, maar zijn er nadien enkele ontwikkelingen ontstaan die deze gebruiksfunctie onder druk hebben gezet of nog verder onder druk gaan zetten. Zo zal op de langere termijn niet alleen de toenemende ruimtevraag voor windenergie en natuurgebieden op zee de toekomstige mogelijkheden voor de visserij beperken. Ook speelt sinds 2017 dat er een gedeeltelijk verbod op de puls visserij is ingesteld, dat de aanlandplicht wordt ingevoerd, de coronacrisis gestart is en kunnen de onderhandelingen tussen het Verenigd Koninkrijk en de EU over de Brexit ertoe leiden dat de ruimte voor de bodemvisserij op de Noordzee sterk wordt ingeperkt. Al deze ontwikkelingen betekenen dat de situatie over een aantal jaren, laat staan in 2040/2050, er wel eens compleet anders uit kan zien dan de huidige situatie.

Daarmee kan het uitvoeren van de waardebepaling zoals die is toegepast in deze verkenning in die zin niet de daadwerkelijke effecten in beeld brengen. De vereenvoudigde aanpak kan wel helpen om een idee te krijgen van de richting van deze effecten.

\subsubsection{Berekeningswijze}

De berekening van de waarden van de verschillende typen visserij is gebaseerd op de VMS-mapping methode ontwikkeld in Hintzen et al. (2012). De economische waarden van de gebieden zijn gebaseerd op de waarden die die gebieden in 2017 vertegenwoordigen voor de volgende visserijtypen:

- Dredge-visserij op schelpdieren met korren/dreggen (voornamelijk spisula en ensis)

- Staandwant- en overige typen kleine zeevisserij (onder andere op tong en zeebaars)

- Pelagische visserij (onder andere op makreel, haring en wijting)

- Borden-, twinrig-, quadrig-, etc. visserij (onder andere op schol en kreeftjes)

- Flyshootvisserij (onder andere op mul en poon)

- Boomkor-, puls-, sumwingvisserij (onder andere op schol en tong) en

- Garnalenvisserij.

De basisgegevens voor de berekening van de waarde van de verschillende gebieden voor de visserij zijn de Vessel Monitoring System (VMS) gegevens, de officiële logboekgegevens, de afslaggegevens en de economische gegevens van de visserij zoals verzameld door Wageningen Economic Research. Deze worden per schip bijgehouden:

- De VMS-gegevens geven inzicht in de locatie en vaarsnelheid van de schepen tijdens een visreis (tijdsinterval voor posities is gemiddeld twee uur).

- De logboekgegevens geven inzicht in de aangevoerde hoeveelheid vis en het gebruikte vistuig per visreis.

- De afslaggegevens geven inzicht in de prijs die op de afslag voor de vis betaald is en de economische gegevens geven inzicht in de verhoudingen tussen de aanvoerwaarde en de toegevoegde waarde per type visserij.

Door de bovenstaande gegevens te combineren, bepalen we de opbrengsten van visgebieden voor de verschillende typen visserij. De berekening van de productiewaarde, toegevoegde waarde en werkgelegenheid bestaat uit de volgende stappen:

1. De gegevens van Nederlands gevlagde schepen in het referentiejaar 2017 vormen de basis.

2. Aan de hand van de snelheid en het gebruikte tuig wordt voor elk van de scheepslocaties tijdens een visreis bepaald of een schip aan het vissen is of aan het stomen of stilliggen.

3. De aangelande hoeveelheid vis wordt per reis gelijkelijk verdeeld over alle locaties waarop het schip aan het vissen is geweest. 
4. De waarde van de aangelande hoeveelheid vis wordt bepaald op basis van de gemiddelde maandelijkse prijzen per vissoort.

5. De waarde van de vis uit een gebied is het totaal van de waarde van de aangelande hoeveelheden vis van alle vislocaties binnen dat gebied.

6. De bijdrage van de gebieden aan de toegevoegde waarde van de visserij is bepaald op basis van de gemiddelde verhouding in de visserij tussen de totale waarde van de vangsten en de bruto toegevoegde waarde. Hierbij is voor de overige kleine zeevisserijen en de schelpdiervisserij gebruikgemaakt van de gemiddelde verhouding tussen besomming en toegevoegde waarde voor deze visserijen samen. Voor de andere visserijtypen is de verhouding per visserijtype gebruikt.

7. Op basis van shapefiles die door Rijkswaterstaat geleverd zijn (die per variant de locaties van de geprojecteerde natuurgebieden en windmolenparken aangeven) en informatie over welke gebieden voor welk type visserij toegankelijk zijn, is per variant bepaald welke gebieden op het NCP in 2040/2050 voor welk type visserij toegankelijk zijn. Hierbij is uitgegaan van het volgende:

- Geen enkele vorm van visserij zal toegestaan zijn in de WOZ-zoekgebieden die gesloten zijn per variant.

- In de varianten is er uitgegaan van een toekomstscenario met Noordzee-akkoord (versie april 2020). Dit is van belang voor de visserijtypes die wel of niet worden toegestaan in de natuurgebieden. In het scenario met Noordzee-akkoord zijn in de berekening de volgende gebieden gesloten voor bodemberoerende visserij: Klaverbank met uitgang van de Botney Cut, Friese Front (zowel VR-gebied als KRM gebied), Borkumse Stenen en Centrale Oestergronden. De Doggersbank (Habitatrichtlijn gebied) wordt gesloten voor alle visserijtypes.

8. De huidige economische bijdrage van de gebieden die voor de visserij in $2040 / 2050$ toegankelijk zouden blijven voor de verschillende typen visserij wordt voor de varianten bepaald.

9. Voor de berekening van de toegevoegde waarde zijn alle productiewaardes met dezelfde omrekenfactor vermenigvuldigd $(0,56)$. Deze omrekenfactor is gebaseerd op die van de totale sector (op basis van meerjarige visserij gegevens Wageningen Economic Research).

10. De indirecte effecten van de aanvoer van goederen en diensten voor visserij op zee op de productiewaarde en toegevoegde waarde zijn bepaald op basis van input-outputtabellen van het CBS die zijn bewerkt door Wageningen Economic Research. Hieruit blijkt dat 1 euro in de visserij ongeveer 0,4 euro in de toeleverende industrie genereert. Dit getal wordt toegepast bij het berekenen van de indirecte productie- en toegevoegde waarde en omvat dus niet de indirecte effecten die ontstaan als gevolg van afvoer/verwerking van goederen en diensten vanuit visserij op zee.

11. Voor het berekenen van de werkgelegenheid is bepaald hoeveel zeedagen er per scheepstype in welk gebied gemaakt worden en hoeveel bemanning aan boord is van die schepen. Op basis daarvan is bepaald wat de verhoudingen zijn qua inzet binnen het NCP in de gebieden die in beide scenario's nog open zouden zijn voor de verschillende typen visserij. Vervolgens zijn deze verhoudingen toegepast op het totaal aantal fte in de visserij, waarmee berekend is hoeveel fte aan welke gebieden is toe te schrijven.

12. De indirecte effecten van de aanvoer van goederen en diensten voor visserij op zee op de werkgelegenheid zijn bepaald op basis van input-outputtabellen van het CBS die zijn bewerkt door Wageningen Economic Research. Hieruit blijkt dat $1 \mathrm{fte}$ in de visserij ongeveer $0,7 \mathrm{fte}$ in de toeleverende industrie genereert. Dit getal wordt toegepast bij het berekenen van de indirecte werkgelegenheid en omvat dus niet de indirecte effecten die ontstaan als gevolg van afvoer/verwerking van goederen en diensten vanuit visserij op zee.

\subsubsection{Bronnen}

In deze sectie beschrijven we welke bronnen gebruikt zijn als basis voor de berekeningen per gebruiksfunctie voor het referentiejaar (2017) en toekomstjaar (2040/2050). Alle monetaire waardes zijn in euro's voor het jaar 2017.

\subsubsection{Olie- en gaswinning}

Olie- en gaswinning op de Noordzee omvat ongeveer 3\% van het Bruto Nationaal Product (CBS, 2016). In 2017 stonden op het Nederlandse deel van de Noordzee 161 productielocaties, waarvan $93 \%$ wordt ingezet voor de winning van gas en $7 \%$ voor de winning van olie (Ecorys, 2017). De meest 
recente verwachting is dat er in 2030 tussen de 60 en 90 productielocaties aanwezig zullen zijn, en in 2040/2050 niet meer dan 5 (bron: EZK schatting, 2020).

De belangrijkste bronnen voor informatie over de productiewaarde en toegevoegde waarde zijn, conform Strietman et al. (2019), de CBS-studie (2016) en de meer recente CBS-gegevens uit 2018 die in de Nationale Rekeningen staan:

Regionale kerncijfers: nationale rekeningen - extra-regio ( $L D$ ) ('extra regio' $=$ Noordzee $+N L$ ambassades): deze extra regio omvat de territoriale wateren, het Nederlandse deel van het continentaal plat in de Noordzee en de zogenaamde territoriale enclaves in het buitenland (Nederlandse ambassades, consulaten, militaire basis, etc.).

De productiewaarde en toegevoegde waarde uit deze statistiek worden toegewezen aan de olie- en gaswinning op zee, conform de methode in CBS (2016).

De indirecte effecten worden, conform Strietman et al. (2019), berekend door dezelfde verhouding tussen direct en indirect toe te passen zoals gehanteerd wordt in de Maritieme Monitor (Ecorys, 2018 ). Dit betekent dat de directe waarden zijn vermenigvuldigd met de volgende factor(en): productiewaarden met 0,56, toegevoegde waarde met 0,59 en werkgelegenheid met 0,97.

\subsubsection{Scheepvaart}

In de Maritieme Monitor (Ecorys, 2018) en de Rijksbegroting (Rijksoverheid, 2019) wordt gerekend met het aantal schepen van zeescheepvaartondernemingen die in Nederland gevestigd zijn. In 2017 omvatte de Nederlandse vloot 2.248 schepen (handelsvaart, zeesleepvaart en waterbouw), waarvan 1.028 onder Nederlandse vlag (Rijksoverheid, 2019). De verwachting is dat de zeescheepvaart zal toenemen met, afhankelijke van het type scheepvaart, tussen de 0,0\% en 2,5\% per jaar (Streng et al., 2018), hetgeen leidt tot een verwachte totale toename van de scheepvaart in 2040/2050 met $39 \%$. Scheepvaartveiligheid wordt gelijk verondersteld tussen de varianten

De basis voor de cijfers over zowel de productiewaarde, toegevoegde waarde als de werkgelegenheid vormt, conform Strietman et al. (2019), de CBS-studie uit 2016 (met cijfers tot en met 2014) en voor de update tot en met 2016 de SBI-code 501-502 Zee- en kustvaart (uit de Nationale Rekeningen). De inschatting van $10 \%$ als aandeel van de Nederlands gevlagde scheepvaart op het NCP (Strietman et al. 2017), passen we toe op de berekeningen van de productiewaarde, toegevoegde waarde en werkgelegenheid.

De verhouding tussen directe en indirecte waardes wordt, conform Strietman et al. (2019), ook voor deze gebruiksfunctie overgenomen uit de Maritieme Monitor (Ecorys, 2018) en toegepast op de berekende waarden (op basis van CBS-cijfers). De omrekeningsfactoren voor direct naar indirect bedragen voor productiewaarde 0,39, voor toegevoegde waarde 0,45 en voor werkgelegenheid 0,90. Let wel, de indirecte effecten betreffen uitsluitend de effecten die ontstaan door de aanvoer van goederen en diensten vanuit andere economische activiteiten aan deze gebruiksfunctie op zee en omvatten dus niet de indirecte effecten die ontstaan als gevolg van afvoer/verwerking van goederen en diensten vanuit deze gebruiksfunctie op zee.

Deze getallen hebben dus betrekking op de Nederlands gevlagde schepen op het NCP, aangezien deze relevant zijn voor de berekening van de effecten van de varianten voor de inrichting van het Nederlands deel van de Noordzee op de Nederlandse economie. Dit betreft daarmee een deel van de totale waarde van het Nederlandse maritieme cluster (zie box 1 in Sectie 4.2.1.2).

\subsubsection{Windmolenparken op zee}

In de berekening van de productiewaarde, toegevoegde waarde en werkgelegenheid in relatie tot windmolenparken op zee maken we onderscheid tussen 'Exploitatie' (i.e. productie en aanlanding) en 'Bouw' (i.e. aanleg en vervanging). In 2017 was er een totaal areaal van $134 \mathrm{~km}^{2}$ aan windmolenparken op zee, met een totale capaciteit van $\sim 1 \mathrm{GW}$. De doelstelling is dat de totale capaciteit groeit naar 11,5 GW in 2030 en tot 40 GW in 2040/2050 (bron: EZK schatting, 2020). 
De belangrijkste bronnen voor de berekeningen betreffen CBS (2016), de Maritieme Monitor (Ecorys, 2017), het rapport Energieakkoord - effecten van de energietransitie op de inzet en kwaliteit van arbeid (EIB, 2016), het rapport De economische bijdrage van windenergie op zee (PWC, 2018) en het rapport Study into levelized cost of energy of seven new wind zones and IJmuiden Ver (BLIX, 2020).

\section{Exploitatie}

De productiewaarde tijdens de exploitatiefase bestaat uit de levering van elektriciteit uit windmolenparken op zee. De productiewaarde is gebaseerd op BLIX (2020), waarbij per wind-op-zee (WOZ) zoekgebied wordt uitgegaan van een dichtheid van $\sim 0,7$ turbines $/ \mathrm{km}^{2}$ en een netto-opbrengst van $\sim 67,6 \mathrm{GWh} /$ turbine/jaar. We hanteren, conform Strietman et al. (2019), een tenderprijs van 9,0 eurocent/kWh in 2017 (incl. exploitatiesubsidies) en 3,5 eurocent/kWh in 2040/2050 (exclusief exploitatiesubsidies en uitgaande van een daling in tenderprijs van 3.5\% per jaar). Er wordt aangenomen dat de Nederlandse economie volledig (100\%) profiteert van de exploitatie van windmolenparken op het NCP.

De toegevoegde waarde wordt bepaald door het verschil tussen de productiewaarde en de productiekosten. De productiekosten zijn, conform Strietman et al. (2019), gebaseerd op PWC (2018) en uitgebreid met kabel aanlandingskosten (PROMOTioN, 2016) (zie Tabel 2.4), waarmee de productiekosten uitkomen op 3,4 eurocent/kWh in 2040/2050 - uitgesplitst naar 2,7 eurocent/kWh voor bouw (gegeven levensduur van 25 jaar; zie onder) en $\sim 0,7$ eurocent/kWh voor operatie \& onderhoud. Aanlandingsverliezen waren ten tijde van deze studie nog niet beschikbaar (zie BLIX, 2020), en worden dus constant verondersteld tussen varianten.

Tabel 2.4 Gemiddelde kosten per onderdeel per MW (x 1.000 euro); het onderdeel operatie en onderhoud is per MW per jaar (x 1.000 euro)

\begin{tabular}{llr} 
& \multicolumn{1}{c}{ Bron } & $2040 / 2050$ \\
\hline Ontwerp \& ontwikkeling & PWC (2018) & 68 \\
\hline Turbines & PWC (2018) & 1.614 \\
\hline Funderingen & PWC (2018) & 278 \\
\hline Substations \& bekabeling (inter-array) & PWC (2018) & 514 \\
\hline Logistiek \& installatie & PWC (2018) & 121 \\
\hline Operatie \& onderhoud & PWC (2018) & 32 \\
\hline Ontmanteling \& hergebruik & PWC (2018) & 191 \\
\hline Aanlanding (kabels) & PROMOTioN (2016) & 212 \\
\hline
\end{tabular}

Tijdens de exploitatiefase bestaat de werkgelegenheid met name uit operatie \& onderhoud. Hierbij gaan we, conform Strietman et al. (2019), uit van 0,1 (directe) fte per MW, gebaseerd op de aanname dat er bij een opgesteld vermogen van 11,5 GW de werkgelegenheid een bandbreedte heeft van 550-1.350 fte (Knol, 2018).

Het is, conform de geraadpleegde bronnen in Strietman et al. (2019), niet bekend wat de indirecte effecten zijn op het gebied van productiewaarde, toegevoegde waarde en werkgelegenheid. Hiervoor nemen wij PM-posten op.

\section{Bouw}

De productiewaarde tijdens de bouwfase bestaat uit het ontwerp \& ontwikkeling, bouw van turbines, funderingen en substations $\&$ bekabeling, logistiek $\&$ installatie, ontmanteling $\&$ hergebruik en aanlanding (i.e. kabels van windmolenpark tot kust) van windmolenparken op zee (zie Tabel 2.4). De productiewaarde voor de bouw van windmolenparken komt daarmee overeen met die van de productiekosten (minus operatie $\&$ onderhoud) in de exploitatiefase (zie boven) - i.e.

$\sim 2,7$ eurocent/kWh. Bij de berekening van de productiewaarde wordt rekening gehouden met het feit dat de Nederlandse economie een gemiddelde bijdrage realiseert van $36 \%$ in de ontwikkeling, bouw en onderhoud van windmolenparken op het NCP (PWC, 2018). 
Om een indicatie te krijgen van de toegevoegde waarde wordt, conform Strietman et al. (2019), de verhouding tussen de productiewaarde en toegevoegde waarde en het aantal werkzame personen (fte) van SBI-09 (Dienstverlening Delfstoffenwinning) in 2016, uit de Nationale Rekeningen van CBS (2018), gebruikt. Daarbij genereert 1 fte ruim 550.000 euro omzet (productiewaarde) en bijna 200.000 euro toegevoegde waarde. Ofwel $36 \%$ van de productiewaarde is toegevoegde waarde.

Voor de berekening van het aantal fte per megawatt voor een windmolenpark op het NCP hanteren we, conform Strietman et al. (2019), de getallen die in het EIB-rapport (EIB, 2016) vermeld staan. Daarmee komt het aantal jaarlijkse fte per MW voor de bouw van een windmolenpark op zee gemiddeld uit op circa 3,3. Hierbij wordt aangenomen dat de Nederlandse werkgelegenheid volledig $(100 \%)$ profiteert van de bouw van windmolenparken op het NCP.

De omrekeningsfactoren voor direct naar indirect bedragen, conform Strietman et al. (2019) en op basis van PWC (2018), 0,47 voor productiewaarde, toegevoegde waarde en werkgelegenheid.

\subsubsection{Visserij}

De basisgegevens voor de analyse van de waarde van de verschillende gebieden voor de visserij zijn: de Vessel Monitoring System (VMS) gegevens, de officiële logboekgegevens, de afslaggegevens en de economische gegevens van de visserij zoals verzameld door Wageningen Economic Research. Al deze gegevens worden per schip bijgehouden:

- De VMS-gegevens geven inzicht in de locatie en vaarsnelheid van de schepen tijdens een visreis (tijdsinterval voor posities is gemiddeld twee uur).

- De logboekgegevens geven inzicht in de aangevoerde hoeveelheid vis, het gebruikte vistuig en fte per visreis.

- De afslaggegevens geven inzicht in de prijs die op de afslag voor de vis betaald is en de economische gegevens geven inzicht in de verhoudingen tussen de aanvoerwaarde en de toegevoegde waarde per type visserij (i.e. 57\%).

Door deze gegevens te combineren kunnen de opbrengsten van visgebieden voor de verschillende typen visserij bepaald worden. Voor de voor deze verkenning uitgevoerde analyse vormen de gegevens van Nederlands gevlagde schepen in het referentiejaar 2017 de basis (i.e. een relatief goed visserij jaar).

De omrekeningsfactoren voor direct naar indirect bedragen, conform Strietman et al. (2019) en op basis van input-outputtabellen van het CBS, 0,40 voor productiewaarde, 0,40 voor toegevoegde waarde en 0,70 voor werkgelegenheid. De indirecte effecten omvatten de aanvoer van goederen en diensten voor visserij op zee, maar niet de indirecte effecten die ontstaan als gevolg van afvoer/verwerking van goederen en diensten vanuit visserij op zee.

\subsubsection{Aqua- en maricultur}

Een gebruiksfunctie die de komende decennia in omvang zou kunnen toenemen is de aquacultuur. Op dit moment is aquacultuur in Nederland klein van omvang en divers van karakter. Zo worden er in de Zeeuwse delta en de Waddenzee vooral schelpdieren, zoals mosselen en oesters, gekweekt. Op de Noordzee zelf wordt de eerste kleinschalige pilot $(1 \mathrm{~km} 2)$ uitgevoerd rondom de kweek van zeewier. Het PBL (2018) ziet potentie in de kweek van schelpdieren, microalgen en macroalgen (zeewier), met als maximale verwachting een groei in zeewierteelt tot 400 km2 in 2040/2050 (bron: RVO schatting, 2020).

Aangezien historische zeewier productie gegevens voor Nederland afwezig zijn, maken we gebruik van het EnAlgae model (zie Van Dijk en Van der Schoot, 2015). Hierbij gaan we uit van een oogst van $11,9 \mathrm{~kg}$ fresh weight (FW) per meter dropper line, een totale dropper line lengte van $3.000 \mathrm{~m} / \mathrm{ha}$ en een prijs van $0,76 € / \mathrm{kg} \mathrm{FW}$. Dit resulteert in een productiewaarde van $27,1 \mathrm{k} € / \mathrm{ha}$ ), productiekosten van $23,6 \mathrm{k} € / \mathrm{ha}$, toegevoegde waarde van 3,5 k€/ha en een arbeidsbehoefte van 0,12 fte/ha. De gebruikte zeewier prijs ligt onder de premium market (voedsel) prijs van $1,00 € / \mathrm{kg} \mathrm{FW}$ gebruikt in Van Dijk en Van der Schoot (2015), omdat het onduidelijk is hoe groot de premium (voedsel) zeewier markt wordt en hoe snel het aanbod van premium (voedsel) zeewier zal stijgen in de toekomst.

De verhouding tussen directe en indirecte waardes wordt gelijk verondersteld met die van de visserij. De omrekeningsfactoren voor direct naar indirect bedragen dus, conform Strietman et al. (2019) en 
op basis van input-outputtabellen van het CBS, 0,40 voor productiewaarde, 0,40 voor toegevoegde waarde en 0,70 voor werkgelegenheid.

\subsubsection{Zandwinning}

Jaarlijks wordt op de Noordzee zeezand gewonnen voor zowel ophoogzand in de bouw als voor kustverdedigingsdoeleinden. Zeezand wordt gewonnen in water met een diepte van ruim twintig meter en op ruime afstand (binnen de 12-mijlszone) van de kust (Noordzeeloket, 2018). In 2017 was de benodigde hoeveelheid suppletiezand 12 miljoen $\mathrm{m}^{3}$ en de hoeveelheid ophoogzand 13 miljoen $\mathrm{m}^{3}$ (PBL, 2019). Vanwege de zeespiegelstijging en toenemende commerciële vraag, wordt verwacht dat de benodigde hoeveelheid suppletiezand en ophoogzand beide toenemen tot 20 miljoen $\mathrm{m}^{3}$ in 2040/2050 (bron: RWS schatting, 2020).

De gebruikte bronnen voor de productiewaarde, toegevoegde waarde en werkgelegenheid zijn, conform Strietman et al. (2019), de CBS- studie (2016) en (voor de meest recente cijfers) SBI code 08 (Delfstoffenwinning; geen olie en gas). De inschatting van 15\% als aandeel van zand gewonnen op zee ten opzichte van het totaal aan zand gewonnen op land en zee (UEPG, 2018), passen we toe op de berekeningen van de productiewaarde, toegevoegde waarde en werkgelegenheid.

Het is, conform de geraadpleegde bronnen in Strietman et al. (2019), niet bekend wat de indirecte effecten zijn op het gebied van productiewaarde, toegevoegde waarde en werkgelegenheid. Hiervoor nemen wij PM-posten op.

\subsection{Natuur/biodiversiteit effectenanalyse}

\subsubsection{Inleiding}

Om een indicatie te krijgen van de richting van de ecologische effecten van de verschillende ruimtelijke inrichtingsvarianten op ecosysteem componenten (vogels, vissen, zeezoogdieren en habitats), wordt gebruikgemaakt van de Cumulatieve Effecten Analyse (CEA; Sectie 2.2.2.1). Om een indicatie te krijgen van de mogelijke natuur/biodiversiteit effecten van windenergie productie in WOZ zoekgebieden op soortgroepen (zeevogels, zeehonden, bruinvis en andere walvisachtigen, vleermuizen, vissen en rifbouwende soorten, wordt gebruikgemaakt van de Expert opinion methode (Sectie 2.2.2.2). Hieronder lichten wij deze methodieken nader toe (Sectie 2.2.2) en gaan nader in op hoe wij die toepassen in deze studie (Sectie 2.2.3).

\subsubsection{Methode}

\subsubsection{CEA methode}

In een CEA wordt het verschil in impact van gebruiksfuncties op de voornaamste ecosysteem componenten (bijvoorbeeld vis, vogels, zeezoogdieren of habitats) berekend tussen een niet beïnvloede situatie, de huidige situatie en een (hypothetische) andere situatie. Daarmee kan inzichtelijk gemaakt worden hoe de ecologische effecten van verschillende beleidsmaatregelen zich tot elkaar verhouden. Een CEA is in feite een soort risicobeoordeling. Dit betekent dat de kennis over het type en mate van verstoring door maritieme gebruiksfuncties gecombineerd wordt met een inschatting van de gevoeligheid van de verschillende ecosysteem componenten voor het type verstoring. Daarmee kunnen de effecten van verschillen in de mate en het type gebruiksfunctie op het ecosysteem geëvalueerd worden.

Voor de beoordeling van de gevolgen van de verschillende varianten voor de inrichting van het Nederlands deel van de Noordzee, is gekozen voor een integrale risicobeoordelingsmethodiek - de zogenaamde cumulatieve effecten analyse (CEA) die recentelijk ontwikkeld is (Knights et al., 2015; Borgwardt et al., 2019). Daarbij is de schatting van het risico (impact) voor natuur een weergave van de blootstelling in combinatie met het mogelijke effect, waarbij:

- De blootstelling gebaseerd is op:

- Het oppervlak van de gebruiksfunctie

- Potentiële verspreiding van de gerelateerde drukfactoren en 
- Relatieve bijdrage van de gebruiksfuncties aan de gerelateerde drukfactoren.

- Het mogelijke effect gebaseerd is op:

- Gevoeligheid van de ecosysteem component

- Veerkracht van de ecosysteem component en

- Persistentie van de drukfactoren.

De output van deze analyse is per gebruiksfunctie een percentage tussen $0 \%$ en $100 \%$, waarbij de $0 \%$ een onverstoorde situatie is terwijl bij $100 \%$ het ecologisch functioneren door deze gebruiksfunctie totaal verstoord is en er daardoor geen natuurwaarde meer is. De precieze waarde is daarbij minder informatief dan de relatieve verschillen tussen de huidige omvang en de verwachte nieuwe omvang.

Met de CEA methodiek zijn in het Nederlandse deel van de Noordzee meer dan 4.000 effectketens in beeld gebracht en semi-kwantitatief en cumulatief ingeschat op basis van gegevens uit de (wetenschappelijke) literatuur en aangevuld met expert judgement van een groot team van experts. Het resultaat hiervan is dat de huidige methodiek nog grotendeels semi-kwantitatief is.

\subsubsection{Expert opinion methode}

Om inzicht te krijgen in wat er wel mogelijk is en wat er niet mogelijk is met betrekking tot verschillen in de waarde voor soorten/soortgroepen tussen de acht WOZ-zoekgebieden op het Nederlands Continentaal Plat (NCP), zijn verschillende WMR experts benaderd hun inschatting en mening te geven aan de hand van een gerichte vragenlijst. Betrokken WMR experts hebben expertise op het gebied van zeevogels, zeehonden, bruinvis, vleermuizen, vissen en benthos (met name rifbouwende soorten). De vragenlijst en de resultaten zijn gerapporteerd in Jongbloed et al. (2020).

\subsubsection{Bronnen}

\subsubsection{CEA methode}

Voor deze studie hanteren we een vergelijkbare aanpak zoals die eerder toegepast is in de studie Natuur Verkenning voor de Noordzee: Voorbeeld uitwerking van een Noordzee bijdrage aan de Natuurverkenningen (zie Jongbloed et al., 2019). Daarmee kunnen semi-kwantitatief de cumulatieve ecologische effecten van gebruiksfuncties en hun drukfactoren over de ecologische componenten voor het NCP in kaart gebracht worden. De gebruikte data zijn afkomstig van de database van het EU project Aquacross (www.aquacross.eu; Borgwardt et al., 2019), geschaald naar het Nederlandse deel van de Noordzee (voor gebruiksfuncties), wetenschappelijke literatuur en aangevuld met expert judgement van een groot team van experts.

De inrichtingsvarianten zijn in de analyse opgenomen op basis van oppervlakte van de gebruiksfuncties. Deze data is beschikbaar gemaakt als onderdeel van de economische effecten analyse (zie Sectie 2.1). Voor de visserij is aanvullende data gebruikt, waarbij de oppervlaktes per visserijvorm voor het referentiejaar 2017 overgenomen zijn van Jongbloed et al. (2019; zie Tabel 2.5) en consistent zijn met die gebruikt in de economische analyse van de visserij (zie Sectie 2.1.3).

Tabel 2.5 Oppervlaktes visserij $\left(\mathrm{km}^{2}\right)$ voor het referentiejaar 2017

\begin{tabular}{|c|c|c|c|}
\hline Sector & Type & $\begin{array}{c}\text { Oppervlakte (\% NCP) } \\
\text { (Jongbloed et al., 2019) }\end{array}$ & Oppervlakte $\left(\mathrm{km}^{2}\right)$ a) \\
\hline Visserij & Bodem beroerend & 81 & 46.559 \\
\hline Visserij & Pelagisch & $1 \mathrm{~b})$ & 575 \\
\hline
\end{tabular}

a) Oppervlakte NCP $=57.480 \mathrm{~km}^{2}$; b) In Jongbloed et al. (2019) geschat op 20\%, maar op basis van recente GIS-analyses aangepast naar $1 \%$.

Voor de varianten zijn de oppervlaktes voor visserij als volgt berekend: 
waarbij de aannames die voor de verschillende gebruiksfuncties zijn gehanteerd zijn weergegeven in Tabel 2.6. Daarbij is uitgegaan van een sluiting van visserijgebieden met Noordzee Akkoord en gedifferentieerd naar de verschillende visserijvormen (zie Tabel 2.7).

Tabel 2.6 Invloed van de gebruiksfuncties op het oppervlak bevisbaar gebied

\begin{tabular}{ll} 
Gebruiksfunctie & Invloed op bevist gebied (oppervlak) visserij \\
Olie- en gaswinning & Oppervlak niet beschikbaar voor visserij (100\% afname) \\
\hline Scheepvaart & Oppervlak wel beschikbaar voor visserij (0\% afname) \\
\hline Windenergie & Oppervlak niet beschikbaar voor visserij (100\% afname) \\
\hline Kabels en leidingen & Oppervlak deels niet beschikbaar voor visserij (10\% afname) \\
\hline Aqua-/Maricultuur & Oppervlak niet beschikbaar voor visserij (100\% afname) \\
\hline Zandwinning & Oppervlak niet beschikbaar voor visserij (100\% afname) \\
\hline Natuur \& biodiversiteit & Uitsluiting visserij natuurgebieden varieert per visserijvorm (Tabel 2.7) \\
\hline
\end{tabular}

Tabel 2.7 Oppervlaktes visserijvormen $\left(\mathrm{km}^{2}\right)$ gesloten in het referentiejaar 2017 en in de situatie zonder en met Noordzee Akkoord

\begin{tabular}{lccc} 
Visserijvorm & Huidige situatie (ref.) & Zonder Noordzee Akkoord & Met Noordzee Akkoord \\
$\begin{array}{l}\text { Bodemberoerende visserij } \\
\text { (1 of meerdere vormen) }\end{array}$ & 2.455 & 6.564 & 13.447 \\
\hline Bodemberoerende visserij (alle) & 181 & 4.290 & 7.765 \\
\hline Staandwantvisserij & 3.042 & 3.042 & 3.042 \\
\hline Pelagische visserij & 160 & 160 & 260 \\
\hline
\end{tabular}

\subsubsection{Expert opinion-methode}

Data voor de Expert opinion methode zijn afkomstig uit de antwoorden op de vragenlijst gericht aan de benaderde WMR experts (zie Sectie 2.2.2.2). De antwoorden op de vragenlijst zijn gerapporteerd in Jongbloed et al. (2020). 


\section{Wind-op-zee zoekgebieden en inrichtingsvarianten}

Dit hoofdstuk geeft een beschrijving van de wind-op-zee (WOZ-)zoekgebieden (Sectie 3.1) en de varianten voor de inrichting van het Nederlandse deel van de Noordzee in 2040/2050 (Sectie 3.2). De tekst in dit hoofdstuk is gebaseerd op en overgenomen uit Beschrijving mogelijke zoekgebieden wind op zee voor de situatie na 2030 (Intern projectgroep NZ programma; Versie 23 mei 2020).

De opgave is om ruimte te verkennen en te zoeken voor windgebieden op zee na 2030. In het Noordzee-akkoord (versie april 2020) staat een indicatie voor de totale capaciteitsomvang van windenergie-op-zee van 20-40 GW. Het identificeren en ontwikkelen van nieuwe windmolenparken zal daarbij plaatsvinden in verschillende fases:

1. Eerst identificeert het Rijk in afstemming met belanghebbenden mogelijke nieuwe WOZzoekgebieden. Met een plan-MER onderzoekt het Rijk deze op hoog abstractieniveau op milieuaspecten, ecologische effecten, effecten op andere gebruiksfuncties en waarden op zee, en kosten. Op basis daarvan kiest het Rijk welke WOZ zoekgebieden het aanwijst en opneemt in het Programma Noordzee 2022-2027.

2. Dan stelt het Rijk een (uitbreiding van de bestaande) routekaart windenergie op zee op voor de periode 2030-2040. Deze geeft aan welke (delen van) WOZ-zoekgebieden daadwerkelijk ontwikkeld zullen worden en wanneer.

3. Tot slot stelt het Rijk kavelbesluiten op die de exacte geografische contouren bevatten van de kavels die het via tenders gunt aan windmolenparkontwikkelaars.

Deze studie correspondeert met de eerste fase, waarin de factoren die mede bepalend zijn voor de selectie van de WOZ-zoekgebieden op hoofdlijnen in kaart worden gebracht. Onderscheid is daarbij te maken tussen algemene uitgangspunten en locatie-specifieke aspecten.

Met betrekking tot de algemene uitgangspunten is par 4.12 uit het Noordzee-akkoord relevant. Daarin wordt aangegeven dat bij de aanwijzing van nieuwe WOZ-zoekgebieden een integraal afwegingskader gehanteerd dient te worden, waarbij ecologie, ander gebruiksfuncties (zoals visserij, olie- en gaswinning en zandwinning), aanlanding, energie-infrastructuur, scheepvaart, oppervlakte van windmolenparken en koppeling met internationale windmolenparken onderzocht en transparant afgewogen moeten worden. Daarnaast zijn er politieke toezeggingen met betrekking tot positie, is er een ruime bandbreedte in te plaatsen capaciteit (20-40 GW), is er potentie voor medegebruik (zoals aqua- en maricultuur), en is er discussie over dichtheid van opgesteld vermogen en mogelijke aanlandingspunten. Over veel van deze aspecten zal niet binnen een paar maanden of zelfs jaren duidelijkheid of een besluit komen. Dat betekent dat er een oplossing gezocht moet worden die aan de ene kant zekerheid biedt voor gebruiksfuncties en aan de andere kant flexibiliteit biedt die het mogelijk maakt deze oplossing aan te passen aan de op een gegeven moment bekende randvoorwaarden en uitgangspunten.

Met betrekking tot de locatie-specifieke aspecten, is in verschillende werksessies met stakeholders en vertegenwoordigers van het Rijk verkend welke WOZ-zoekgebieden in aanmerking zouden kunnen komen - daarbij rekening houdend met de eisen uit het Noordzee-akkoord en de mogelijkheden die potentiële gebieden bieden ten aanzien van internationale (stroom)connecties en waterstof $\left(\mathrm{H}_{2}\right)$ productie en de ideeën die aangedragen zijn door de visserij. Op basis van dit proces zijn uiteindelijk acht gebieden geïdentificeerd als mogelijke WOZ-zoekgebieden.

\subsection{Kenmerken wind-op-zee zoekgebieden}

In een werksessie is per WOZ-zoekgebied geïdentificeerd wat de kansen of bedreigingen van de gebruiksfuncties en ecologie zijn. Daarbij is gebruikgemaakt van kaartmateriaal dat in het Noordzee overleg gehanteerd is voor dichtheden van vogels en opbrengsten van visserij en sessies die in februari 2020 zijn gehouden met ecologen en energie-deskundigen, aangevuld met de bevindingen 
van de Noordzee Energiesysteem Outlook (NEO) bijeenkomst van 11 maart 2020. De acht gebieden geïdentificeerd als mogelijke WOZ-zoekgebieden liggen verspreid over het NCP (zie Figuur 3.1), en zijn als volgt gekenmerkt (Tabel 3.1).

Tabel 3.1 Locatie, grootte (in $\mathrm{km}^{2}$ ) en capaciteit (in GW) van de geïdentificeerde WOZzoekgebieden

\begin{tabular}{|c|c|c|c|}
\hline & Locatie & Grootte $\left(\mathrm{km}^{2}\right)$ & GW (bij $10 \mathrm{MW} / \mathrm{km}^{2}$ ) \\
\hline WOZ1 & Op grens met Norfolk Boreas & 940 & 9 \\
\hline WOZ2 & Ten noorden van IJmuiden-ver & 1.050 & 10 \\
\hline WOZ4 & Defensie oefengebied ten noorden van Wadden a) & 1.357 & 13 \\
\hline WOZ5 & Driehoek op grens met Duitsland & 616 & 6 \\
\hline WOZ7 & Ten oosten van Klaverbank & 1.000 & 10 \\
\hline \multirow[t]{3}{*}{ WOZ8 } & Ten noordwesten van Texel b) & 150 & 1,5 \\
\hline & & $5.882+$ & $58+$ \\
\hline & & $1.357 a)+150 b)$ & $13 a)+1,5 b)$ \\
\hline
\end{tabular}

a) WOZ4 is pas een reële optie als er een alternatief is voor het defensie oefengebied is; b) WOZ8 kan niet in combinatie met WOZ2.

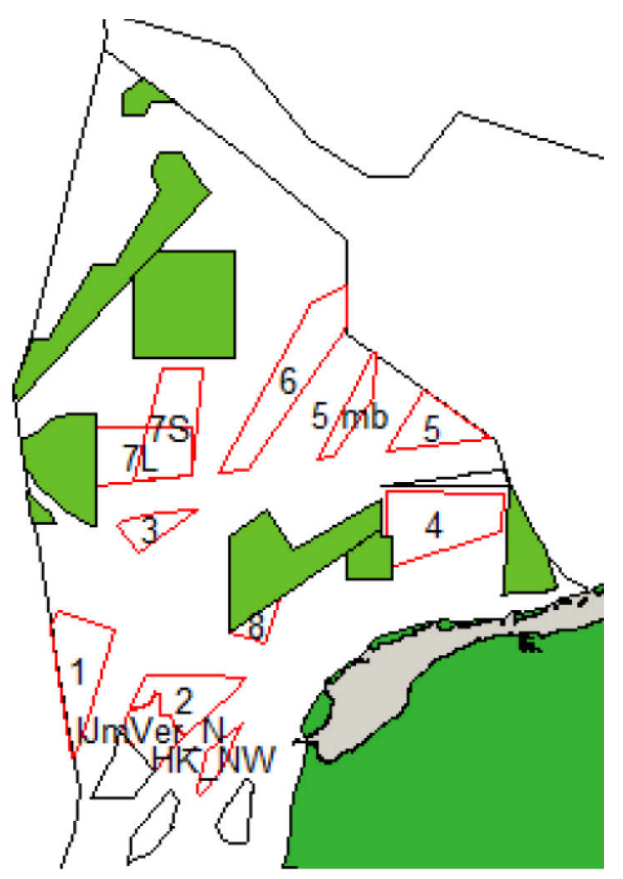

Figuur 3.1 Geschatte locatie van de geïdentificeerde WOZ-zoekgebieden Bron: Deetman et al. (2020).

Hieronder volgt voor elk WOZ zoekgebied een overzicht van de belangrijkste kenmerken.

\section{WOZ zoekgebied 1 (WOZ1): Op de grens met Norfolk Boreas:}

Opmerking: De scheepvaartcorridor naar Newcastle loopt hier door heen

- Grootte: bruto ongeveer $940 \mathrm{~km}^{2}$

- Gemiddelde dichtheid van voorkomen van zeevogels

- Belangrijk gebied voor tongvisserij

- Drukke scheepvaartroute aan oostzijde, en minder druk aan westzijde

- Kans om te combineren met aansluiting op netwerk van de UK

- Kans om te combineren met Carbon Capture \& Storage (CCS) opslag in lege gasvelden (waarvoor energie nodig is)

- Kans om te combineren met waterstof $\left(\mathrm{H}_{2}\right)$ productie op zee

- Ver weg voor arbeidsintensief medegebruik 


\section{WOZ zoekgebied 2 (WOZ2): Ten noorden van IJmuiden-ver}

Grootte: Begrenzing hangt af van i) ruimte die vrijkomt door opgeheven platforms en verplaatsen Defensie-oefengebied, en ii) een deel niet gebruikt maar wel aangewezen gebied ter grootte van

$310 \mathrm{~km}^{2}$. Verdere ontwikkeling is alleen logisch met deze beide gebieden samen.

- Grootte: ongeveer $1.050 \mathrm{~km}^{2}$

- Gemiddelde dichtheid zeevogels (iets minder dan 1)

- Belangrijk gebied voor tongvisserij (ook economisch)

- Economisch clustervoordeel met IJmuiden-ver

- Kans om te combineren met aansluiting UK

- Kans om te combineren met CCS opslag (waarvoor energie nodig is)

- Kans om te combineren met $\mathrm{H}_{2}$-productie en opslag in lege gasvelden/zout cavernes

- Relatief dichter bij de kust

\section{WOZ zoekgebied 3 (WOZ3): Ten noordwesten van IJmuiden-ver, tussen de twee scheepvaartroutes in}

Dit is de vrije noordpunt van het gebied waar gasplatforms langer blijven staan

- Grootte: ongeveer $276 \mathrm{~km}^{2}$

- Gemiddelde dichtheid zeevogels

- Belangrijk gebied voor (tong)visserij

- Kans om te combineren met aansluiting UK

- Kans om te combineren met CCS opslag (waarvoor energie nodig is)

- Kans om te combineren met $\mathrm{H}_{2}$-productie en opslag in lege gasvelden/zout cavernes

- Ver weg voor arbeidsintensief medegebruik

\section{WOZ zoekgebied 4 (WOZ4): Defensie oefengebied ten noorden van de Wadden}

Dit is het gebied waar nu een internationaal (NAVO) vlieg/schiet oefengebied is. Dit is pas een reële optie als er een alternatief is voor het oefengebied dat echter op zee in NL luchtruim niet te vinden is.

- Grootte: ongeveer $1.357 \mathrm{~km}^{2}$

- Gemiddelde dichtheden zeevogels, wel voorkomen zeekoeten (Friese Front)

- Voorkomen van bruinvis en gewone zeehond

- Relatief minder belangrijke visgebieden (deel Scholbox)

- Ligt dicht bij de Kust en Groningen

- Aansluiting door Wadden

\section{WOZ zoekgebied 5 (WOZ5): Driehoek op grens met Duitsland, ten oosten van nieuwe} scheepvaart passage

Begrensd door nieuwe clearway aan westkant naar Kattegat en mogelijke verbreding diepwaterroute

- Grootte: ongeveer $616 \mathrm{~km}^{2}$

- Lage dichtheden zeevogels

- Voorkomen van bruinvis en gewone zeehond

- Kansen voor natuurontwikkeling

- Relatief minder belangrijke visgebieden

- Ligt dicht bij de kust en Groningen

- Kans om te combineren met aansluiting Duitsland

- Kans om te combineren met $\mathrm{H}_{2}$-productie en bijmengen met gas

- Kans om te combineren met bijvoorbeeld opwekking elektriciteit door middel van zonne-energie

- Search and Rescue is verder weg van Den Helder maar Delfzijl dichterbij

- Aansluiting kabel/leiding door Wadden

- Mogelijk stratificatie zeewater (verminderde stroming) bij veel turbines

WOZ zoekgebied 6 (WOZ6): Gebied ten noorden van Friese Front, ten westen van nieuwe scheepvaart passage

Begrensd door nieuwe clearway aan oostkant naar Kattegat en mogelijke toekomstige route naar Barentszzee. Exacte indeling van dit gebied is niet bekend. Hangt af van oa discussie met Duitsland, vooral vanwege de route van tankers en uit te voeren Formal Safety Assessment. Het streven is om hier IMO routes van te maken. Dit duurt echter enige jaren. Als proxy (en niet als concreet voorstel) is 
nu uitgegaan van de helft in zoekgebied scheepvaart en helft ten westen daar van om de relatieve belangrijkheid van dit gebied te kunnen bepalen.

- Grootte: ongeveer $2.000 \mathrm{~km}^{2}$ maar dit is variabel. Uitbreiding naar het westen is relatief onbeperkt zolang er een doorgang naar een toekomstige Barentszzee-route mogelijk blijft

- Voorkomen van Sterns en Visdief

- Relatief minder belangrijke visgebieden

- Kans op ontwikkeling natuurwaarden

- Kans om te combineren met $\mathrm{H}_{2}$-opwekking

- Search and Rescue is verder weg

- Mogelijk stratificatie water

- Kans om te combineren met bijvoorbeeld opwekking door middel van zonne-energie

WOZ zoekgebied 7 (WOZ7): Ten oosten van Klaverbank

Begrensd door Klaverbank aan westkant en mogelijke toekomstige route naar Barentszzee.

- Grootte: ongeveer $1.000 \mathrm{~km}^{2}$ maar dat is variabel omdat er geen belemmeringen zijn in de omgeving voor wat betreft de omvang

- Gemiddelde dichtheid zeevogels

- Kans op ontwikkeling natuurwaarden

- Relatief minder belangrijke visgebieden

- Kans om te combineren met UK parken

- Kans om te combineren met $\mathrm{H}_{2}$-productie

- Search and Rescue is ver weg

\section{WOZ zoekgebied 8 (WOZ8): Ten noordwesten van Texel}

Dit is genoemd in NZ akkoord door de vissers. Als Defensiegebied boven IJmuiden-ver omklapt, komt dit gebied weer te vervallen. Dit gebied kan dus niet in combinatie met gebied 2.

- Grootte: ongeveer $150 \mathrm{~km}^{2}$

- Binnen bereik foeragerende kustvogels

- Hoge dichtheid zeevogels

- Relatief minder belangrijke visgebieden (Scholbox)

- Gebied te klein voor gelijkstroom

- Kans om te combineren met $\mathrm{H}_{2}$-productie

- Vlak bij druk scheepvaartroutes

\subsection{Definitie inrichtingsvarianten}

Gedurende de periode februari tot en met juni 2020 zijn er, op iteratieve wijze met belanghebbenden van ministeries en kennisinstellingen, varianten voor de inrichting van de Noordzee gedefinieerd. Hierbij werden varianten doorgerekend, tussenresultaten besproken en alternatieve varianten gedefinieerd. In deze studie rapporteren we de laatste set van 4 varianten, welke gekenmerkt wordt door (zie Tabel 3.2) een vrijwel volledige afname in olie- en gaswinning, een $39 \%$ toename in scheepvaart, een groei in windmolenparken van 11,5 GW tot 2030 en nog eens 28 GW tot 2040/2050, een opschaling van aqua/maricultuur tot $400 \mathrm{~km}^{2}$ (medegebruik in windmolenparken), een $60 \%$ toename in zandwinning, een uitbreiding van natuurgebieden volgens het Noordzee-akkoord (versie april 2020) en een toe-/afname in visgebied afhankelijk van de ontwikkelingen in andere gebruiksfuncties.

Tabel 3.2 Globale kenmerken van de inrichtingsvarianten

\begin{tabular}{lcr} 
& 2017 & $2040 / 2050$ \\
Olie- en gaswinning & 161 platforms & 5 platforms \\
\hline Scheepvaart & & $+39 \%$ \\
\hline Windmolenparken & $1,0 \mathrm{GW}$ & $39,5-40,5 \mathrm{GW}$ \\
\hline Aqua-/maricultuur & $1 \mathrm{~km}^{2}$ & $400 \mathrm{~km}^{2}$ \\
\hline Zandwinning & 25 miljoen m & $40 \mathrm{miljoen}^{3}$ \\
\hline Natuur \& biodiversiteit & Huidige natuurgebieden & Conform Programma Noordzee \\
\hline Visserij & Visgebied afhankelijk van ontwikkeling andere gebruiksfuncties
\end{tabular}


Binnen deze globale kenmerken van de varianten zijn er locatie-specifieke verschillen tussen de varianten op basis van de geselecteerde WOZ-zoekgebieden. Daarbij wordt gestreefd naar een additionele capaciteit van ongeveer $28 \mathrm{GW}$ en wordt uitgegaan van een dichtheid van $10 \mathrm{MW} / \mathrm{km}^{2}$. De 4 varianten onderscheiden zich in globale locatie van de WOZ-zoekgebieden (zie Tabel 3.3), met gebieden meer in het zuiden (Combinatie Zuid), een mix van energiecluster in zuiden en noorden (Mix Energiehubs), met gebieden meer in het noorden (Combinatie Noord) en met gebieden met kleinere afstand tot de kust (Dichtbij Energievraag).

Tabel 3.3 Locatie-specifieke kenmerken van de varianten

\begin{tabular}{|c|c|c|c|c|c|}
\hline Gebied & $\begin{array}{c}\text { GW } \\
(b i j 10 \\
\left.M W / \mathrm{km}^{2}\right)\end{array}$ & $\begin{array}{c}\text { Variant } 1 \\
\text { 'Combinatie } \\
\text { Zuid' }\end{array}$ & $\begin{array}{l}\text { Variant } 2 \\
\text { 'Mix } \\
\text { Energiehubs' }\end{array}$ & $\begin{array}{c}\text { Variant } 3 \\
\text { 'Combinatie } \\
\text { Noord' }\end{array}$ & $\begin{array}{c}\text { Variant } 4 \\
\text { 'Dichtbij } \\
\text { Energievraag' }\end{array}$ \\
\hline WOZ2 & $7(+3)$ & $7+3$ & 10 & & $7+3$ \\
\hline wOZ3 & 3 & 3 & & & \\
\hline wOZ5 & 6 & 6 & 6 & 6 & 6 \\
\hline WOZ6 & 20 & & 4 & 13 & \\
\hline woz7 & 10 & & & 10 & \\
\hline WOZ8 b) & 1,5 & & & & \\
\hline
\end{tabular}

a) WOZ4 is pas een reële optie als er een alternatief is voor het defensie oefengebied is; b) WOZ8 kan niet in combinatie met WOZ2.

Enkele opmerkingen met betrekking tot deze 4 varianten voor de inrichting van de Noordzee:

- Optimale eenheden van een veelvoud van 2 GW, conform het 2 GW 525 kV HVDC-netconcept, zijn nog niet meegenomen. Dit is deels op te vangen met variatie in dichtheid (bijvoorbeeld $940 \mathrm{~km}^{2} \mathrm{kan}$ $4 * 2 \mathrm{GW}$ bij $10 \mathrm{MW} / \mathrm{km}^{2}$ of $5 * 2 \mathrm{GW}$ bij $11 \mathrm{MW} / \mathrm{km}^{2}$ ).

- Alle WOZ-zoekgebieden in de variant Combinatie Zuid liggen, behalve Gebied 5 (WOZ5), ten zuiden van de diepwater-scheepvaartroute.

- In de variant Mix Energiehubs worden de windmolenparken geconcentreerd rondom 2 'energiehubs' (kunstmatige eilanden) waar (een deel van) de elektriciteit wordt omgezet naar waterstof en vervolgens naar land getransporteerd.

- De variant Combinatie Noord ligt ten noorden van de diepwater-scheepvaartroute. De vorm en omvang van Gebied 6 (WOZ6) zijn nog redelijk flexibel vast te stellen. In dit geval kiezen we voor $13 \mathrm{GW}$.

- In de variant Dichtbij Energievraag komen de windmolenparken zo dicht mogelijk bij de industriële clusters aan de kust (Eemshaven, Noordzeekanaalgebied, Rijnmondgebied).

- Scheepvaartveiligheid wordt gelijk verondersteld tussen de varianten. 


\section{$4 \quad$ Resultaten}

In dit hoofdstuk worden de resultaten van de economische en natuur/biodiversiteit impact analyses gepresenteerd voor ieder van de wind-op-zee (WOZ) zoekgebieden (Sectie 4.1) en voor ieder van de inrichtingsvarianten voor de Noordzee (Sectie 4.2).

\subsection{Wind-op-zee zoekgebieden}

In deze sectie presenteren we de resultaten van de economische (Sectie 4.1.1) en natuur/biodiversiteit (Sectie 4.1.2) Kentallen Analyse voor ieder van de WOZ-zoekgebieden (zoals gedefinieerd in Sectie 3.1).

\subsubsection{Economisch effecten}

In deze sectie presenteren we de economische waardes van de WOZ-zoekgebieden, in termen van productiewaarde, toegevoegde waarde en werkgelegenheid, voor windmolenpark exploitatie (Sectie 4.1.1.1), windmolenpark bouw (Sectie 0) en visserij (Sectie 0).

\subsubsection{Windmolenpark exploitatie}

Windmolenpark exploitatie is het meest efficiënt (i.e. grootste toegevoegde waarde per $\mathrm{km}^{2}$ ) in, respectievelijk, wind-op-zee zoekgebied WOZ3, WOZ5, WOZ4 en WOZ6; windmolenpark exploitatie is het minst efficiënt in WOZ7 (Tabel 4.1). De efficiëntie is, met name, afhankelijk van de bouwkosten (laagst in WOZ3, WOZ4 en WOZ5), het rendement van de windmolenparken (hoogst in WOZ3, WOZ6 en WOZ5) en de kabel aanlandingskosten (laagst in WOZ4, WOZ8 en WOZ3).

Naast de efficiëntie van de windmolenparken op zich, spelen ook de omvang van de windmolenparken (bijvoorbeeld WOZ3 is klein), de locatie van de windmolenparken ten opzichte van elkaar (potentie voor het vormen van clusters) en de aanlandingslocaties (dichtbij vraag; aansluitend bij netwerken op land) een rol.

Tabel 4.1 Directe, indirecte en totale productiewaarde ( $P W$; in $\mathrm{mln} . €$ ), toegevoegde waarde (TW; in $\mathrm{mln} . €$ ) en werkgelegenheid (in $1.000 \mathrm{fte}$ ) in windmolenpark exploitatie per wind-op-zee zoekgebied

\begin{tabular}{|c|c|c|c|c|c|c|c|c|}
\hline & $\begin{array}{l}\text { WOZ1 } \\
\text { (9GW) }\end{array}$ & $\begin{array}{l}\text { Woz2 } \\
\text { (10GW) }\end{array}$ & $\begin{array}{l}\text { woz3 } \\
\text { (3GW) }\end{array}$ & $\begin{array}{l}\text { Woz4 } \\
\text { (13GW) }\end{array}$ & $\begin{array}{l}\text { WOZ5 } \\
\text { (6GW) }\end{array}$ & $\begin{array}{l}\text { woz6 } \\
(17 \mathrm{GW})\end{array}$ & $\begin{array}{l}\text { WOZ7 } \\
\text { (10GW) }\end{array}$ & $\begin{array}{c}\text { WOZ8 } \\
(1,5 \mathrm{GW})\end{array}$ \\
\hline \multicolumn{9}{|l|}{ PW } \\
\hline Indirect & PM & $\mathrm{PM}$ & PM & PM & PM & PM & PM & PM \\
\hline Totaal & $1.494+\mathrm{PM}$ & $1.549+\mathrm{PM}$ & $512+P M$ & $2.014+\mathrm{PM}$ & $983+\mathrm{PM}$ & $2.812+\mathrm{PM}$ & $1.631+\mathrm{PM}$ & $232+\mathrm{PM}$ \\
\hline Direct & 49 & 59 & 42 & 90 & 44 & 103 & 32 & 10 \\
\hline Indirect & PM & PM & PM & PM & PM & PM & PM & PM \\
\hline Totaal & $49+P M$ & $59+P M$ & $42+\mathrm{PM}$ & $90+P M$ & $44+\mathrm{PM}$ & $103+P M$ & $32+\mathrm{PM}$ & $10+P M$ \\
\hline $\mathrm{TW} / \mathrm{km}^{2}$ & 0,05 & 0,06 & 0,14 & 0,07 & 0,07 & 0,06 & 0,03 & 0,06 \\
\hline \multicolumn{9}{|l|}{ FTE } \\
\hline Totaal & $1,0+P M$ & $1,0+\mathrm{PM}$ & $0,3+\mathrm{PM}$ & $1,3+\mathrm{PM}$ & $0,6+P M$ & $1,8+\mathrm{PM}$ & $1,0+P M$ & $0,1+\mathrm{PM}$ \\
\hline
\end{tabular}




\subsubsection{Windmolenpark bouw}

Windmolenpark bouw heeft de grootste toegevoegde waarde per $\mathrm{km}^{2}$ in, respectievelijk, wind-op-zee zoekgebied WOZ7, WOZ6 en WOZ1; de laagste in WOZ4 (Tabel 4.). In tegenstelling tot windmolenpark exploitatie, leiden juist hogere bouwkosten (hoogst in WOZ7, WOZ6 en WOZ1) tot een hogere toegevoegde waarde in windmolenpark bouw. De rentabiliteit van windmolenpark exploitatie is, echter, bepalend voor het al dan niet exploiteren van windmolenparken op zee.

Tabel 4.2 Directe, indirecte en totale productiewaarde ( $P W$; in $\mathrm{mln}$. $€$ ), toegevoegde waarde (TW; in $\mathrm{mln} . €$ ) en werkgelegenheid (in $1.000 \mathrm{fte}$ ) in windmolenpark bouw per wind-op-zee zoekgebied

\begin{tabular}{|c|c|c|c|c|c|c|c|c|}
\hline & woz1 & woz2 & woz3 & woz4 & woz5 & woz6 & woz7 & woz8 \\
\hline \multicolumn{9}{|l|}{ PW } \\
\hline Direct & 412 & 424 & 133 & 546 & 268 & 775 & 458 & 63 \\
\hline Totaal & 606 & 623 & 196 & 803 & 393 & 1.140 & 673 & 93 \\
\hline \multicolumn{9}{|l|}{ TW } \\
\hline Indirect & 70 & 72 & 23 & 93 & 46 & 133 & 78 & 11 \\
\hline Totaal & 220 & 227 & 71 & 292 & 143 & 414 & 245 & 34 \\
\hline \multicolumn{9}{|l|}{ FTE } \\
\hline Direct & 1,3 & 1,3 & 0,4 & 1,7 & 0,8 & 2,4 & 1,4 & 0,2 \\
\hline
\end{tabular}

\subsubsection{Visserij}

Uit Sectie 4.2.1.5 is gebleken dat de verschillende varianten minimale verschillen laten zien in de waardes die gebieden die nog wel bevist kunnen worden vertegenwoordigen. Als we specifiek inzoomen op de acht wind-op-zee (WOZ) zoekgebieden en de waardes die zij voor de typen visserij vertegenwoordigen, dan blijken er wel degelijk verschillen te zijn: het verschilt per type visserij welke waarde deze gebieden vertegenwoordigen (zie Tabel 4.3 tot en met Tabel 4.6).

Tabel 4.3 Directe productiewaarde ( $P W$; in $\mathrm{mln} . €)$ in visserij per visserijtype, per wind-op-zee zoekgebied

\begin{tabular}{|c|c|c|c|c|c|c|c|c|}
\hline Visserijtype a) & woz1 & woz2 & wOZ3 & Woz4 & WOZ5 & woz6 & Woz7 & WOz8 \\
\hline Dredgers & 0,00 & 0,00 & 0,00 & 0,00 & 0,00 & 0,00 & 0,00 & 0,00 \\
\hline Staandwant & 0,00 & 0,00 & 0,00 & 0,00 & 0,00 & 0,00 & 0,00 & 0,00 \\
\hline Bordentrawls/twinrig & 0,01 & 0,00 & 0,02 & 0,00 & 0,01 & 0,91 & 0,12 & 0,00 \\
\hline Flyshoot & 0,00 & 0,04 & 0,00 & 0,06 & 0,00 & 0,00 & 0,02 & 0,01 \\
\hline Garnalenvisserij & 0,00 & 0,00 & 0,00 & 0,00 & 0,00 & 0,00 & 0,00 & 0,00 \\
\hline Totaal & 1,82 & 0,54 & 0,12 & 0,07 & 1,35 & 2,56 & 0,33 & 0,01 \\
\hline
\end{tabular}

a) Dredgers = Visserij op schelpdieren met korren/dreggen; Staandwant = Overige typen kleine zeevisserij (lijn, staand want, overige

tuigtypen); Pelagische trawlers = Grote zeevisserij; Bordentrawls/twinrig = Visserij met borden, twinrig, quadrig, etc.; Flyshoot = Visserij met flyshoot; Boomkor/sumwing/ puls = Visserij met boomkor, sumwing, puls; Garnalenvisserij = Garnalenvisserij.

Boomkor/sumwing/puls visserij vertegenwoordigt een belangrijke waarde in de WOZ-zoekgebieden, met name in de WOZ1, WOZ2, WOZ5 en WOZ6. Dit type visserij behelst, gemiddeld, ongeveer $80 \%$ van alle typen visserij in deze acht WOZ-zoekgebieden, terwijl deze WOZ-zoekgebieden bijna $10 \%$ van de totale boomkor-,sumwing- en pulsvisserij op het NCP vertegenwoordigen. 
Tabel 4.4 Directe toegevoegde waarde (TW; in $\mathrm{mln}$. $€$ ) in visserij per visserijtype, per wind-op-zee zoekgebied

\begin{tabular}{|c|c|c|c|c|c|c|c|c|}
\hline Visserijtype & woz1 & woz2 & WOZ3 & WOZ4 & woz5 & woz6 & WOZ7 & Woz8 \\
\hline Dredgers & 0,00 & 0,00 & 0,00 & 0,00 & 0,00 & 0,00 & 0,00 & 0,00 \\
\hline Staandwant & 0,00 & 0,00 & 0,00 & 0,00 & 0,00 & 0,00 & 0,00 & 0,00 \\
\hline Bordentrawls/twinrig & 0,00 & 0,00 & 0,01 & 0,00 & 0,00 & 0,52 & 0,07 & 0,00 \\
\hline Flyshoot & 0,00 & 0,02 & 0,00 & 0,04 & 0,00 & 0,00 & 0,01 & 0,01 \\
\hline Garnalenvisserij & 0,00 & 0,00 & 0,00 & 0,00 & 0,00 & 0,00 & 0,00 & 0,00 \\
\hline Totaal & 1,03 & 0,31 & 0,07 & 0,04 & 0,77 & 1,46 & 0,19 & 0,01 \\
\hline
\end{tabular}

a) Zie Tabel 4.3 .

De visserij met borden, twinrig, quadrig, etc. (Bordentrawls/twinrig) vertegenwoordigt met name in de WOZ6 en WOZ7 een belangrijke waarde, en behelst, gemiddeld, ongeveer $15 \%$ van alle typen visserij in deze acht WOZ-zoekgebieden. Deze WOZ-zoekgebieden vertegenwoordigen iets meer dan $10 \%$ van de totale visserij met borden, twinrig, quadrig, etc. op het NCP.

Tabel 4.5 Directe werkgelegenheid (in fte) in visserij per visserijtype, per wind-op-zee zoekgebied

\begin{tabular}{|c|c|c|c|c|c|c|c|c|}
\hline Visserijtype & woz1 & woz2 & woz3 & Woz4 & woz5 & woz6 & WOZ7 & Woz8 \\
\hline Dredgers & 0,00 & 0,00 & 0,00 & 0,00 & 0,00 & 0,00 & 0,00 & 0,00 \\
\hline Staandwant & 0,00 & 0,07 & 0,00 & 0,00 & 0,00 & 0,00 & 0,00 & 0,00 \\
\hline Bordentrawls/twinrig & 0,08 & 0,16 & 0,11 & 0,28 & 0,19 & 3,47 & 0,30 & 0,20 \\
\hline Flyshoot & 0,18 & 0,56 & 0,01 & 0,48 & 0,00 & 0,00 & 0,05 & 0,07 \\
\hline Garnalenvisserij & 0,00 & 0,00 & 0,00 & 0,05 & 0,00 & 0,00 & 0,00 & 0,00 \\
\hline Totaal & 9,12 & 4,46 & 0,72 & 1,44 & 5,94 & 10,7 & 1,84 & 0,51 \\
\hline
\end{tabular}

a) Zie Tabel 4.3 .

De overige visserij typen behelzen een relatief kleine waarde in de acht WOZ-zoekgebieden. De grote zeevisserij (Pelagische trawlers) vertegenwoordigt in de WOZ6 en WOZ7 een (beperkte) waarde. De Flyshoot visserij vormt met name in de WOZ2 en WOZ4 een (beperkte) waarde.

Tabel 4.6 Directe, indirecte en totale productiewaarde ( $P W$; in $\mathrm{mln}$. $€$ ), toegevoegde waarde (TW; in $\mathrm{mln} . €$ ) en werkgelegenheid (in $1.000 \mathrm{fte}$ ) in visserij per wind-op-zee zoekgebied

\begin{tabular}{|c|c|c|c|c|c|c|c|c|}
\hline & woz1 & Woz2 & woz3 & WOZ4 & woz5 & Woz6 & Woz7 & Woz8 \\
\hline \multicolumn{9}{|l|}{ PW } \\
\hline Direct & 1,82 & 0,54 & 0,12 & 0,07 & 1,35 & 2,56 & 0,33 & 0,01 \\
\hline Totaal & 2,54 & 0,75 & 0,17 & 0,10 & 1,89 & 3,59 & 0,47 & 0,02 \\
\hline \multicolumn{9}{|l|}{ TW } \\
\hline Indirect & 0,41 & 0,12 & 0,03 & 0,02 & 0,31 & 0,58 & 0,08 & 0,00 \\
\hline Totaal & 1,45 & 0,43 & 0,10 & 0,06 & 1,08 & 2,04 & 0,27 & 0,01 \\
\hline \multicolumn{9}{|l|}{ FTE } \\
\hline Direct & 0,009 & 0,004 & 0,001 & 0,001 & 0,006 & 0,011 & 0,002 & 0,001 \\
\hline
\end{tabular}

Tot slot, de garnalenvisserij (Garnalenvisserij), schelpdier visserij (Dredgers) en kleinschalige zeevisserij (Staandwant) zijn, in vergelijking met de andere type visserijen, relatief beperkt actief in 
de acht WOZ-zoekgebieden, Alleen WOZ4 vertegenwoordigt een (zeer beperkte) waarde voor de garnalenvisserij, De reden hiervoor is dat deze typen visserij voornamelijk actief zijn in de kustzone en niet in de verschillende WOZ-zoekgebieden (die verder op zee liggen),

\subsubsection{Natuur/biodiversiteit effecten}

In deze sectie presenteren we de resultaten van de expert inschatting (Jongbloed et al., 2020) over welke WOZ-zoekgebieden meer of minder effecten zullen hebben op de soortgroepen: zeevogels (Sectie 4.1.2.1), zeehonden (Sectie 4.1.2.2), bruinvis en andere walvisachtigen (Sectie 4.1.2.3), vleermuizen (Sectie 4.1.2.4), vissen (Sectie 4.1.2.5) en rifbouwende soorten (Sectie 4.1.2.6). Tot slot zijn de risico's van de 8 WOZ-zoekgebieden voor alle soortgroepen in een overzicht weergegeven (zie Sectie 4.1.2.7).

\subsubsection{Zeevogels}

Voor zeevogels kan op basis van de expertinschattingen het volgende geconcludeerd worden:

- Zeevogels betreft een gemeenschap bestaande uit veel soorten en de respons verschilt per soort.

- Zeevogel-windmolenpark gevoeligheidskaart (geïntegreerd over soorten en ruimtelijk) is beschikbaar en bruikbaar, maar inmiddels wel enigszins verouderd en niet compleet.

- Beperkingen van de huidige kennis:

- Doorwerking populatieniveau is niet bekend; en

- Gedrag binnen/buiten windmolenparken is niet bekend.

- Expert inschattingen per WOZ-zoekgebied (zie ook Tabel 4.7):

- De minste effecten worden verwacht voor WOZ1, WOZ2, WOZ6 en WOZ8; en

- De meeste effecten worden verwacht voor WOZ3, WOZ5 en WOZ7.

\subsubsection{Zeehonden}

Voor zeehonden kan op basis van de expert inschattingen het volgende geconcludeerd worden:

- Er zijn aanwijzingen dat de zeehonden met de huidige menselijke activiteiten beperkt zijn in hun populatie ontwikkeling, het mechanisme is echter nog onduidelijk.

- Beperkingen van de huidige kennis:

- Effecten in operationele fase zijn minder goed bekend;

- Er is nog geen zicht op het effect van opeenhoping van verschillende menselijke activiteiten (toerisme, aquacultuur, visserij, mijnen, transport, constructie, opwarming) en natuurlijke factoren in het leefgebied van zeehonden;

- Doorwerking op populatieniveau is niet bekend; en

- Gedrag binnen/buiten windmolenparken is niet bekend.

- Expert inschattingen per WOZ zoekgebied (zie ook Tabel 4.7):

- Voor alle WOZ-zoekgebieden zijn de potentiële effecten op de grijze zeehond groot; en

- Voor WOZ3, WOZ6 en WOZ7 zijn de potentiële effecten op de gewone zeehond onduidelijk; voor de overige gebieden zijn de potentiële effecten groot.

\subsubsection{Bruinvis en andere walvisachtigen}

Voor bruinvis en andere walvisachtigen kunnen op basis van de expert inschattingen de volgende beperkingen geconcludeerd worden:

- Beperkingen van de huidige kennis:

- effecten in operationele fase zijn minder goed bekend;

- doorwerking populatieniveau is niet bekend; en

- gedrag binnen/buiten windmolenparken is niet bekend.

- Expert inschattingen per WOZ zoekgebied (zie ook Tabel 4.7):

- de minste effecten worden verwacht voor WOZ1;

- de meeste effecten worden verwacht voor WOZ2, WOZ3, WOZ4 en WOZ8; en

- voor WOZ5, WOZ6 en WOZ7 zijn de potentiële effecten onduidelijk. 


\subsubsection{Vleermuizen}

Voor vleermuizen kan op basis van de expert inschattingen het volgende geconcludeerd worden (zie ook Tabel 4.7):

- Kennis over de verspreiding is (zeer) beperkt: er zijn slechts voor 2 van de 8 WOZ-zoekgebieden gegevens bekend.

- Voor WOZ1 en WOZ2 zijn de potentiële effecten groot. Voor de overige gebieden zijn de potentiële effecten onduidelijk.

- Om verantwoorde uitspraken te kunnen doen over de risico's van windmolenparken is aanvullend onderzoek nodig, waarvan een deel al loopt in het kader van het WOZEP-programma.

\subsubsection{Vissen}

Voor vissen kan op basis van de expert inschattingen het volgende geconcludeerd worden:

- Vissen betreft relatief diverse gemeenschap bestaande uit vele soorten en de respons is afhankelijk van de soort.

- Zeer diverse groep die zonder verdere prioritering zo ongeveer overal even veel voorkomt en met een zelfde kwetsbaarheid. De invloed van WOZ-zoekgebieden valt weg bij aggregatie waardoor de inschatting neutraal wordt voor alle gebieden (zie ook Tabel 4.7).

\subsubsection{Rifbouwende soorten}

Voor rifbouwende soorten kan op basis van de expert inschattingen het volgende geconcludeerd worden (zie ook Tabel 4.7):

- Kansen voor ontwikkeling van biogene riffen zijn ingeschat op basis van verspreidingskaarten van rifbouwende soorten.

- Expert inschattingen per WOZ zoekgebied (zie ook Tabel 4.7):

- WOZ4 biedt de meeste kans (potentieel geschikt voor alle (4) beschouwde rifbouwende soorten);

- WOZ7 biedt de minste kans (potentieel geschikt voor 1 rifbouwende soort, de gewone mossel), gevolgd door WOZ6 (potentieel geschikt voor 2 rifbouwende soorten); en

- De overige zoekgebieden (WOZ1, WOZ2, WOZ3, WOZ5 en WOZ8) bieden kans voor 3 rifbouwende soorten.

- Mogelijke impact op benthos in het algemeen ontbreekt: effecten door verandering van bodemsamenstelling (op bodemleven en ecosysteem) en aangroei op palen (door toename van filtratie fytoplankton).

\subsubsection{Risico's van WOZ-zoekgebieden voor soortgroepen}

In de bovenstaande Secties zijn per soortgroep de geschatte effecten van WOZ-zoekgebieden weergegeven. In deze sectie zijn de risico's samengevoegd tot één overzicht (Tabel 4.7). Let wel, deze inschatting is van slechts één (of twee) experts per soortgroep, op basis van kennis en ervaring, waarbij er geen gericht onderzoek aan vooraf is gegaan. 
Tabel 4.7 Expertinschatting van de risico's van de 8 WOZ-zoekgebieden per soortgroep (aangepaste weergave van Tabel 6 uit Jongbloed et al. (2020)): Laag (negatieve effecten zijn naar verwachting minimaal); Hoog (verwachte negatieve effecten); Neutraal (geen bijzonderheden/gebied is niet van specifiek belang); Onduidelijk (onvoldoende kennis om (on)geschiktheid in te schatten); Kans (windmolenpark is kans voor soort(groep)/Positieve effecten verwacht). Bij elke inschatting is een indicatie van de zekerheid gegeven: Laag (L); Medium/matig (M); Redelijk/relatief hoog (R); niet ingeschat of niet relevant (-). Dit betreft een samenvatting; bij de inschattingen zijn soms opmerkingen gemaakt die alleen in de bovenstaande Secties zijn weergegeven en/of in het rapport van Jongbloed et al. (2020).

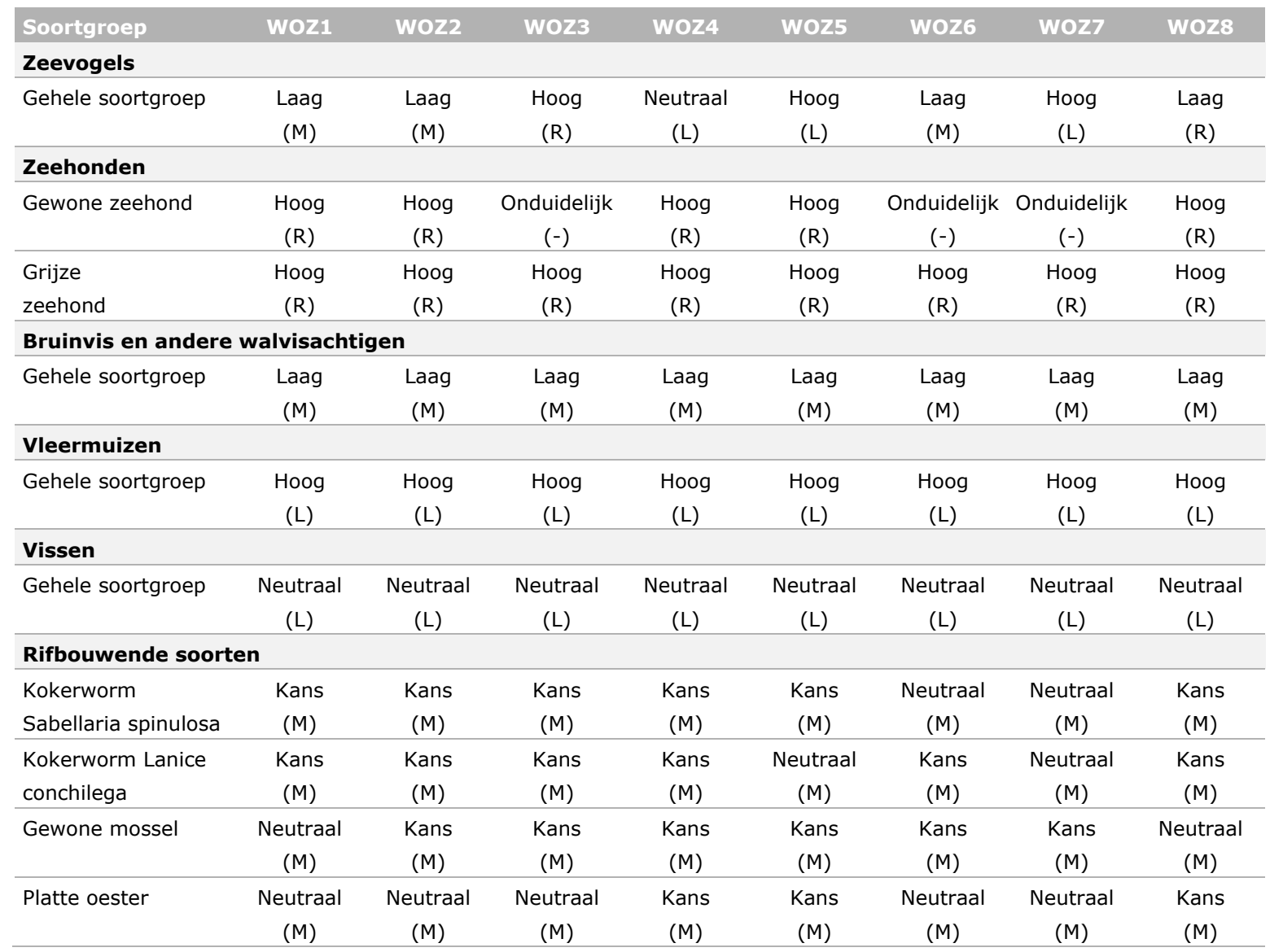

$\mathrm{Er}$ is een volgorde aan te brengen in de WOZ-zoekgebieden op basis van de mogelijke impact op natuurwaarden. Die volgorde voor WOZ-zoekgebieden wordt enigszins beïnvloed door de selectie van de soort(groep)en. Aan de hand van de inschattingen in Tabel 4.7 zijn de gebieden hieronder weergegeven op volgorde van meest geschikt naar minst geschikt:

- Voor alle soortgroepen behalve rifbouwers (uitsluitend op basis van potentieel negatieve impact):

- WOZ1

- WOZ2, WOZ6 en WOZ8

- WOZ4

- WOZ5 en

- WOZ3 en WOZ7.

- Voor alle soortgroepen, inclusief kansen voor rifbouwende soorten:

- WOZ1

- WOZ2 en WOZ8

- WOZ4 en WOZ6

- WOZ5 en WOZ7 en

- WOZ3.

De vier varianten voor de inrichting van Noordzee in 2040/2050 bestaan uit verschillende combinaties van selecties uit de 8 individuele WOZ-zoekgebieden die zijn beoordeeld (Tabel 3.3). Op basis van de 
hierboven genoemde rangschikking van meest geschikte WOZ-zoekgebieden, zijn vervolgens de vier varianten gerangschikt naar de natuurimpact op volgorde van meest geschikt naar minst geschikt:

- Variant 2 (Mix Energiehubs)

- Variant 1 (Combinatie Zuid)

- Variant 4 (Dichtbij energievraag) en

- Variant 3 (Combinatie Noord').

Hierbij moet worden opgemerkt dat de verschillen tussen deze vier varianten betreffende de ingeschatte natuurimpact gering zijn. Vanwege de grote mate van onzekerheid, wegens gebrek aan beschikbare gegevens, moeten deze resultaten voor de rangschikking van WOZ-zoekgebieden en de varianten met voorzichtigheid worden behandeld.

\subsection{Inrichtingsvarianten}

In deze sectie presenteren we de resultaten van de economische (Sectie 4.2.1) en natuur/biodiversiteit (Sectie 4.2.2) Kentallen Analyse voor ieder van de varianten voor de inrichting van de Noordzee (zoals gedefinieerd in Sectie 3.2).

\subsubsection{Economisch effecten}

In deze sectie presenteren we de economische waarde (2017) en effecten van de varianten voor de inrichting van de Noordzee (2040/2050) in termen van productiewaarde, toegevoegde waarde en werkgelegenheid, voor de verschillende gebruiksfuncties (secties 4.2.1.1 tot en met 4.2.1.7) evenals totaal over alle gebruiksfuncties (Sectie 4.2.1.8).

\subsubsection{Olie- en gaswinning}

Olie- en gaswinning op het NCP is een relatief belangrijke sector voor de economie van Nederland, en representeert ongeveer 3\% van het Bruto Nationaal Product (CBS, 2016). In 2017 stonden op het Nederlandse deel van de Noordzee 161 productielocaties (Ecorys, 2017), goed voor een productiewaarde van 5.010 miljoen euro, een toegevoegde waarde van 4.580 miljoen euro en een werkgelegenheid van 7.400 fte (zie Tabel 4.).

Tabel 4.8 Directe, indirecte en totale productiewaarde ( $P W$; in $\mathrm{mln} . €$ ), toegevoegde waarde (TW; in $\mathrm{mln}$. €) en werkgelegenheid (in $1.000 \mathrm{fte}$ ) in olie- en gaswinning, voor 2017 en varianten in $2040 / 2050$

\begin{tabular}{|c|c|c|c|c|c|}
\hline & 2017 & Variant 1 & Variant 2 & Variant 3 & Variant 4 \\
\hline \multicolumn{6}{|l|}{ PW } \\
\hline Direct & 3.200 & 99 & 99 & 99 & 99 \\
\hline Totaal & 5.010 & 155 & 155 & 155 & 155 \\
\hline \multicolumn{6}{|l|}{ TW } \\
\hline Indirect & 1.700 & 53 & 53 & 53 & 53 \\
\hline Totaal & 4.580 & 142 & 142 & 142 & 142 \\
\hline \multicolumn{6}{|l|}{ FTE } \\
\hline Direct & 3,8 & 0,1 & 0,1 & 0,1 & 0,1 \\
\hline
\end{tabular}

De meest recente verwachting is dat er in 2040/2050 niet meer dan 5 olie- en gasproductielocaties aanwezig zullen zijn (bron: EZK schatting, 2020) - i.e. een groefactor van 0,03. Dit leidt tot een scherpe reductie in productiewaarde (tot 155 miljoen euro), toegevoegde waarde (tot 142 miljoen euro) en werkgelegenheid (tot $230 \mathrm{fte}$ ). Daarmee zou olie- en gaswinning een gebruiksfunctie met geen economische waarde van betekenis worden. Er zijn geen verschillen tussen varianten want in 
ieder van de varianten voor de inrichting (van het Nederlands deel) van de Noordzee worden olie- en gaswinning op dezelfde wijze afgebouwd en vinden de platforms zich buiten de WOZ-zoekgebieden.

\subsubsection{Scheepvaart}

De Nederlandse scheepvaart op het NCP is, na olie- en gaswinning, de belangrijkste economische sector op de Noordzee. In 2017 omvatte de Nederlandse vloot 2.248 schepen (handelsvaart, zeesleepvaart en waterbouw), waarvan 1.028 onder Nederlandse vlag (Rijksoverheid, 2019), goed voor productiewaarde van 800 miljoen euro, een toegevoegde waarde van 290 miljoen euro en een werkgelegenheid van 2.800 fte (zie Tabel 4.). Deze waardes hebben betrekking op de Nederlands gevlagde schepen op het NCP (relevant voor de berekening van de effecten van de varianten voor de inrichting van het Nederlands deel van de Noordzee op de Nederlandse economie), en betreft daarmee een klein deel van de totale waarde van het Nederlandse maritieme cluster (zie box 1).

Tabel 4.9 Directe, indirecte en totale productiewaarde ( $P W$; in $\mathrm{mln} . €$ ), toegevoegde waarde (TW; in $\mathrm{m} / \mathrm{n}$. $€$ ) en werkgelegenheid (in $1.000 \mathrm{fte}$ ) in scheepvaart, voor 2017 en varianten in 2040/2050

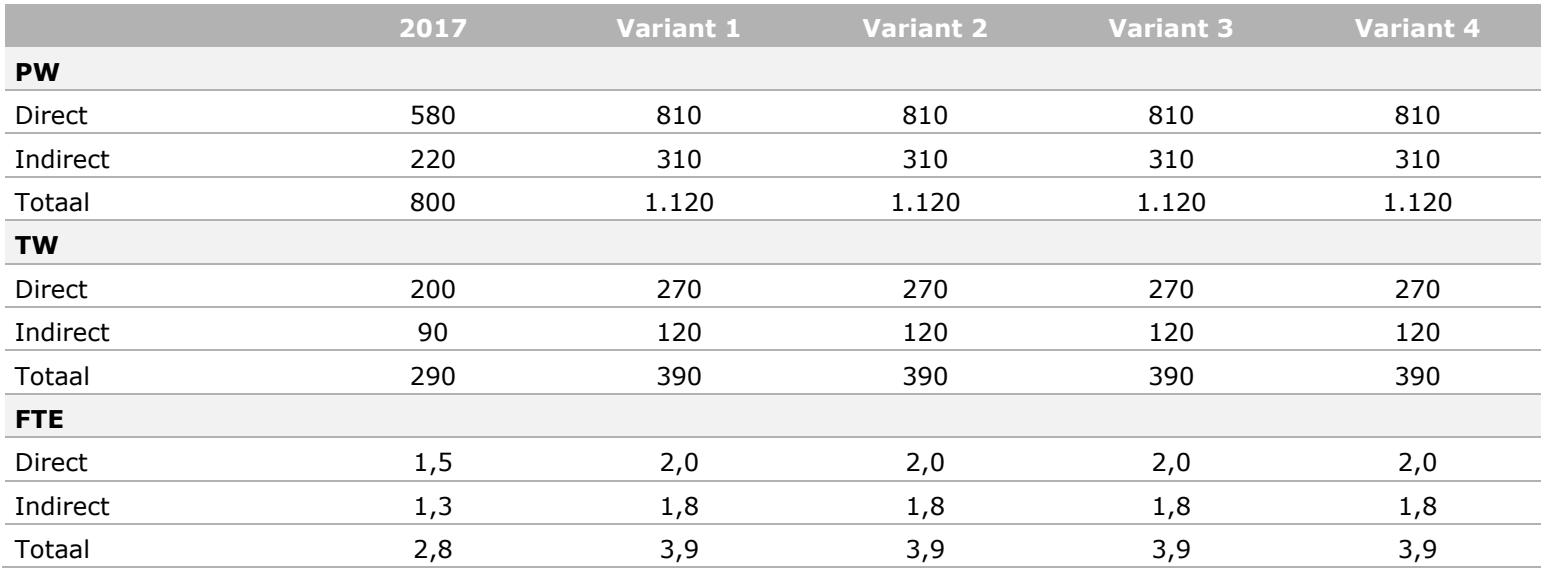

De verwachting is dat de scheepvaart op de Noordzee met tussen de 0,0\% en 2,5\% per jaar zal toenemen (Streng et al., 2018), hetgeen leidt tot een verwachte totale toename van de scheepvaart in 2040/2050 met 39\% (groeifactor 1,39). Dit leidt tot een toename in productiewaarde (tot

1.120 miljoen euro), toegevoegde waarde (tot 390 miljoen euro) en werkgelegenheid (tot 3.900 fte). Daarmee blijft scheepvaart een gebruiksfunctie van relatief groot economische belang. Er zijn geen verschillen tussen varianten want ieder van de varianten voor de inrichting (van het Nederlands deel) van de Noordzee garandeert op dezelfde wijze, via aangewezen vaarroutes en veiligheidszones, dezelfde doorgang van de scheepvaart op het NCP. Scheepvaartveiligheid wordt gelijk verondersteld tussen de varianten.

\section{Box 1 Het Nederlandse maritieme cluster in 2017 (NML, 2018)}

Het Nederlandse maritieme cluster omvat de sectoren havens, offshore, maritieme toeleveranciers, scheepsbouw, zeevaart, waterbouw, maritieme dienstverlening en kennisinstituten, binnenvaart, Koninklijke Marine, jachtbouw/watersportindustrie en visserij. Deze sectoren realiseerden in 2017 een productiewaarde van 54,5 miljard euro en een toegevoegde waarde van 23,3 miljard euro (i.e. $3,3 \%$ van het binnenlands bruto product), en gaven daarbij werkgelegenheid aan 271.500 werknemers (i.e. $3,0 \%$ van de Nederlandse beroepsbevolking).

\subsubsection{Windmolenpark exploitatie}

Windmolenpark exploitatie (i.e. productie en aanlanding) op het NCP is, in vergelijking tot andere gebruiksfuncties, een relatief kleine economische sector op de Noordzee. In 2017 was er een totaal areaal van $134 \mathrm{~km}^{2}$ met een totale capaciteit van $\sim 1 \mathrm{GW}$ aan windmolenparken op zee, goed voor een exploitatie productiewaarde van 300+PM miljoen euro, toegevoegde waarde van 120+PM miljoen euro 
en werkgelegenheid van 100+PM fte (zie Tabel 4.10). De indirecte effecten zijn niet bekend en, dus, nemen we hiervoor PM-posten op.

De doelstelling is dat de totale capaciteit van windmolenparken op zee groeit tot ongeveer $40 \mathrm{GW}$ in 2040/2050 (bron: EZK schatting, 2020). Dit leidt tot een toename in directe exploitatie productiewaarde (tot $\sim 6.600+\mathrm{PM}$ miljoen euro), toegevoegde waarde (tot $\sim 325+\mathrm{PM}$ miljoen euro) en werkgelegenheid (tot $\sim 4.150+\mathrm{PM} \mathrm{fte}$ ). ${ }^{1}$ Daarmee zou windmolenpark exploitatie een gebruiksfunctie met relatief groot economisch belang worden.

Tabel 4.10 Directe, indirecte en totale productiewaarde (PW; in mln. $€$ ), toegevoegde waarde (TW; in $\mathrm{mln}$. €) en werkgelegenheid (in $1.000 \mathrm{fte}$ ) in windmolenpark exploitatie, voor 2017 en varianten in $2040 / 2050$

\begin{tabular}{|c|c|c|c|c|c|}
\hline & 2017 & Variant 1 & Variant 2 & Variant 3 & Variant 4 \\
\hline \multicolumn{6}{|l|}{ PW } \\
\hline Direct & 300 & 6.500 & 6.650 & 6.730 & 6.510 \\
\hline Totaal & $300+P M$ & $6.500+P M$ & $6.650+P M$ & $6.730+P M$ & $6.510+P M$ \\
\hline \multicolumn{6}{|l|}{ TW } \\
\hline Indirect & PM & PM & PM & PM & PM \\
\hline Totaal & $120+P M$ & $340+P M$ & $320+P M$ & $300+P M$ & $340+P M$ \\
\hline \multicolumn{6}{|l|}{ FTE } \\
\hline Direct & 0,1 & 4,1 & 4,2 & 4,2 & 4,1 \\
\hline
\end{tabular}

Hoewel de verschillen tussen de varianten relatief klein zijn, lijken met name Variant 1 (Combinatie Zuid) en Variant 4 (Dichtbij Energievraag) relatief aantrekkelijk (op basis van toegevoegde waarde). Dit wordt met name verklaard door de relatief lage bouwkosten, het relatief hoge rendement en/of de relatief lage aanlandingskosten (kabels) van de in deze varianten opgenomen windmolenparken. Belangrijk is op te merken dat de rentabiliteit van windmolenpark exploitatie bepalend is voor het al dan niet exploiteren van windmolenparken op zee.

\subsubsection{Windmolenpark bouw}

Windmolenpark bouw (i.e. aanleg en vervanging) op het NCP is, in vergelijking tot andere gebruiksfuncties, een relatief kleine economische sector op de Noordzee. In 2017 was er, zoals gezegd, een totaal areaal van $134 \mathrm{~km}^{2}$ met een totale capaciteit van $\sim 1 \mathrm{GW}$ aan windmolenparken op zee, goed voor een bouw productiewaarde van 160 miljoen euro, toegevoegde waarde van 60 miljoen euro en werkgelegenheid van 130 fte (zie Tabel 4.11).

\footnotetext{
1 Het verschil in toename in productiewaarde ( factor 20) en toegevoegde waarde ( factor 3) van 2017 naar 2040/2050, wordt verklaard door een combinatie van lagere tenderprijs in 2040/2050 (9,0 eurocent/kWh in 2017 tegenover 3,5 eurocent/kWh in 2040/2050) en toename in productiekosten ( $\sim$ factor 30).
} 
Tabel 4.11 Directe, indirecte en totale productiewaarde ( $P W$; in $\mathrm{mln}$. $€$ ), toegevoegde waarde (TW; in $\mathrm{mln}$. €) en werkgelegenheid (in $1.000 \mathrm{fte}$ ) in windmolenpark bouw, voor 2017 en varianten in $2040 / 2050$

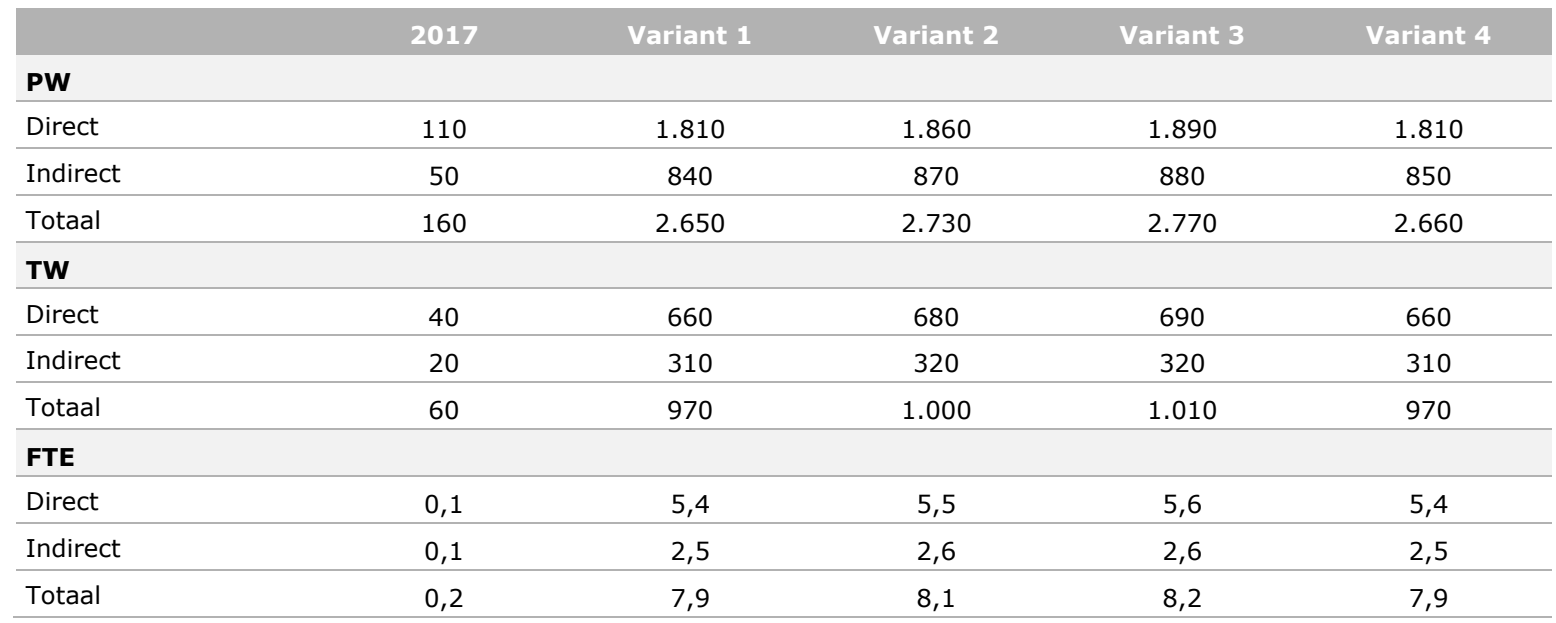

De doelstelling is dat de totale capaciteit van windmolenparken op zee groeit tot $\sim 40 \mathrm{GW}$ in 2040/2050 (bron: EZK schatting, 2020). Dit leidt tot een toename in bouw productiewaarde (tot $\sim 2.700$ miljoen euro), toegevoegde waarde (tot 990 miljoen euro) en werkgelegenheid (tot $\sim 8.025 \mathrm{fte}$ ). Daarmee wordt windmolenpark bouw een gebruiksfunctie met relatief groot economisch belang.

Ook hier zijn de verschillen tussen de varianten relatief klein, maar lijken met name Variant 2 (Mix Energiehubs) en Variant 3 (Combinatie Noord) relatief aantrekkelijk (op basis van toegevoegde waarde). Dit is in tegenstelling tot windmolenpark exploitatie, omdat windmolenpark bouw daar juist een kostenpost is (i.e. hoe hoger de bouwkosten hoe lager de exploitatie baten). Nogmaals, rentabiliteit van windmolenpark exploitatie is bepalend voor het al dan niet exploiteren van windmolenparken op zee.

\subsubsection{Visserij}

Visserij op het NCP is, in vergelijking tot andere gebruiksfuncties, een relatief kleine economische sector op de Noordzee. In de volgende tabellen staan de huidige productiewaarde (PW), toegevoegde waarde (TW) en werkgelegenheid (fte) aangegeven voor de visserij op het NCP (i.e. exclusief de Zeeuwse Delta en de Waddenzee) buiten de windmolenparken en natuurgebieden die voor (bepaalde delen van) de visserij in 2040/2050 nog open zijn. De waardes zijn niet een projectie van toekomstige visserij waardes, maar zijn gebaseerd op de huidige economische waardes (2017) van de WOZzoekgebieden en natuurgebieden die onderzocht worden per variant.

Tabel 4.12 Directe productiewaarde (PW; in m/n. $€$ ) in visserij per visserijtype, voor 2017 en varianten in 2040/2050 a)

\begin{tabular}{|c|c|c|c|c|c|c|}
\hline \multirow[t]{2}{*}{ Visserijtype b) } & \multicolumn{2}{|c|}{2017} & \multirow[t]{2}{*}{ Variant 1} & \multirow[t]{2}{*}{ Variant 2} & \multirow[t]{2}{*}{ Variant 3} & \multirow[t]{2}{*}{ Variant 4} \\
\hline & Totaal & NCP & & & & \\
\hline Dredgers & 10,1 & 9,6 & 9,6 & 9,6 & 9,6 & 9,6 \\
\hline Pelagische trawlers & 121,7 & 0,6 & 0,5 & 0,5 & 0,4 & 0,5 \\
\hline Bordentrawls/twinrig & 19,6 & 10,3 & 5,9 & 5,0 & 4,9 & 5,9 \\
\hline Boomkor/sumwing/puls & 176,6 & 56,7 & 42,9 & 41,4 & 43,6 & 44,8 \\
\hline Garnalenvisserij & 823,0 & 40,2 & 39,4 & 39,4 & 39,4 & 39,4 \\
\hline Totaal & 435,9 & 120,2 & 99,5 & 97,1 & 99,1 & 101,4 \\
\hline
\end{tabular}

a) Alle waardes corresponderen met die van de waardes van de opengebleven gebieden in 2017; b) Zie Tabel 4.3. 
De directe productiewaarde van de visserij op het NCP bedroeg 120 miljoen euro in 2017 (zie Tabel 4.12 ). Dit is $28 \%$ van de totale productiewaarde van de Nederlandse visserij die in dat jaar zowel binnen als buiten het NCP gegenereerd werd. De productiewaarde is het hoogste bij de gebieden die in Variant 4 buiten de WOZ-zoekgebieden vallen en bedraagt 101,4 miljoen euro (84\% van de productiewaarde op het NCP in 2017). De productiewaarde is het laagst voor Variant 2 en bedraagt 97,1 miljoen euro ( $81 \%$ van de productiewaarde op het NCP in 2017).

Tabel 4.13 Directe toegevoegde waarde (TW; in $\mathrm{mln} . €$ ) in visserij per visserijtype, voor 2017 en varianten in 2040/2050 a)

\begin{tabular}{|c|c|c|c|c|c|}
\hline Visserijtype b) & 2017 & Variant 1 & Variant 2 & Variant 3 & Variant 4 \\
\hline Dredgers & 5,5 & 5,5 & 5,5 & 5,5 & 5,5 \\
\hline Staandwant & 0,2 & 0,2 & 0,2 & 0,2 & 0,2 \\
\hline Bordentrawls/twinrig & 5,9 & 3,4 & 2,8 & 2,8 & 3,4 \\
\hline Flyshoot & 1,4 & 0,4 & 0,4 & 0,4 & 0,4 \\
\hline Garnalenvisserij & 22,9 & 22,5 & 22,5 & 22,5 & 22,5 \\
\hline Totaal & 68,5 & 56,7 & 55,3 & 56,5 & 57,8 \\
\hline
\end{tabular}

a) Alle waardes corresponderen met die van de waardes van de opengebleven gebieden in 2017; b) Zie Tabel 4.3.

De directe toegevoegde waarde van de visserij op het NCP bedroeg 68,5 miljoen euro in 2017 (zie Tabel 4.13). Voor de toegevoegde waardes zijn alle productiewaardes met dezelfde omrekenfactor vermenigvuldigd $(0,57)$. Deze is gebaseerd op de sector en geldt dus voor elk type visserij. De interpretatie van de resultaten is dus hetzelfde als die benoemd voor de productiewaarde.

De directe werkgelegenheid in de visserij op het NCP bedroeg bijna $910 \mathrm{fte}$ in 2017 (zie Tabel 4.14). Net als bij de productiewaarde en de toegevoegde waarde is de werkgelegenheid het hoogste bij de gebieden die in Variant 4 buiten de WOZ-zoekgebieden en natuurgebieden vallen en bedraagt $\sim 811 \mathrm{fte}$ ( $89 \%$ van de huidige waarde op het NCP). De werkgelegenheid is het laagste bij de overgebleven gebieden in Variant 2 en bedraagt daar 792 fte ( $87 \%$ van de huidige waarde op het NCP).

Tabel 4.14 Directe werkgelegenheid (in fte) in visserij per visserijtype, voor 2017 en varianten in 2040/2050 a)

\begin{tabular}{|c|c|c|c|c|c|}
\hline Visserijtype b) & 2017 & Variant 1 & Variant 2 & Variant 3 & Variant 4 \\
\hline Dredgers & 318,8 & 318,8 & 318,8 & 318,8 & 318,8 \\
\hline Staandwant & 36,5 & 35,6 & 35,6 & 35,6 & 35,6 \\
\hline Bordentrawls/twinrig & 57,5 & 34,4 & 31,0 & 31,0 & 34,3 \\
\hline Flyshoot & 15,8 & 8,9 & 9,0 & 9,6 & 8,6 \\
\hline Garnalenvisserij & 186,0 & 181,5 & 181,5 & 181,5 & 181,5 \\
\hline Totaal & 907,3 & 802,3 & 792,3 & 804,0 & 810,6 \\
\hline
\end{tabular}

a) Alle waardes corresponderen met die van de waardes van de opengebleven gebieden in 2017; b) Zie Tabel 4.3.

In de bovenstaande tabellen staan de berekeningen voor de waardes van de gebieden die buiten de WOZ-zoekgebieden en natuurgebieden vallen. Hieruit blijkt ook dat de economische waarde van de opengebleven gebieden in de varianten verschilt per type visserij:

- Voor de Bordentrawls/twinrig visserij wordt duidelijk dat de waarde van de opengebleven gebieden in de varianten lager ligt dan in de uitgangsituatie. In Variant 3, bijvoorbeeld, representeren deze ongeveer de helft van de productiewaarde en toegevoegde waarde op het NCP in 2017. De bordentrawlers vissen immers vrij noordelijk op het NCP, waar de grootste en meeste WOZzoekgebieden liggen. De totale productiewaarde werd in 2017 voor ongeveer de helft buiten het NCP 
gegenereerd. Daarmee vertegenwoordigen de WOZ-zoek- en natuurgebieden in de vier varianten dus ongeveer een kwart van de totale productiewaarde voor dit type visserij.

- Voor de Flyshoot visserij is de productie en toegevoegde waarde van de gebieden die buiten de zoek- en natuurgebieden vallen in alle vier de varianten circa 30\% van deze waardes op het NCP. Dit lijkt veel, maar de Flyshoot visserij vist voornamelijk buiten het NCP. Zo werd circa $90 \%$ buiten en $10 \%$ op het NCP zelf gerealiseerd.

- Voor de boomkor-/sumwing-/pulsvisserij representeren de nog opengebleven gebieden in de varianten circa $75 \%$ van de productie en toegevoegde waarde op het NCP in 2017. Ook hier geldt dat de grootste deel van de opbrengst buiten het NCP gerealiseerd wordt (bijna 70\%).

- De garnalenvisserij vindt vooral plaats in de kustzone en op de Waddenzee. De opbrengst van de Waddenzee is niet meegenomen in de berekeningen, omdat deze niet op het NCP gegenereerd wordt. Wel is meegenomen de waarde van de garnalenvisserij op de Noordzee, inclusief de door deze visserij veel beviste kustzone. Omdat de WOZ-zoekgebieden zich niet dichtbij de kust bevinden, en daarmee de waarde van deze gebieden voor de garnalenvisserij relatief gering is, is de productiewaarde van de nog opengebleven gebieden in de varianten vergelijkbaar met de huidige productiewaarde in 2017.

- Op basis van de totale waarde (binnen en buiten NCP), de waarde op het NCP en de effecten van de varianten per visserij type, kan worden geconcludeerd dat Bordentrawls/twinrig visserij de grootste impact ondervindt van de sluiting van visgebieden in de varianten ( $\sim 25 \%$ reductie in productiewaarde), gevolgd door Boomkor/sumwing/puls visserij ( $\sim 8 \%$ reductie in productiewaarde) en Flyshoot visserij ( $\sim 7 \%$ reductie in productiewaarde). Daarmee kan dit dus gevolgen hebben voor deze typen visverwerkende industrieën en visserij gemeenschappen.

De directe en indirecte economische waardes per variant voor de visserijsector als geheel (zie Tabel 4.15) laten zien dat de onderlinge verschillen tussen de waardes in de overgebleven gebieden in alle vier de varianten gering is. Dit komt omdat in de varianten een combinatie van WOZ-

zoekgebieden gehanteerd wordt waarvan de som ongeveer gelijk is. Per individueel WOZ-zoekgebied worden de verschillen in economische warde per type visserij zichtbaarder (zie Sectie 0).

De verschillen die er tussen de varianten zijn, zijn als volgt (zie Tabel 4.15). De directe en indirecte economische waardes voor de visserijsector op het NCP laten zien dat de overgebleven gebieden in Variant 2 (Mix Energiehubs) een lagere waarde representeren dan in de andere varianten, aangezien in deze variant de voor de visserij relatief waardevolle WOZ-zoekgebieden 1, 5 en 6 gecombineerd worden. De gebieden in Variant 4 (Dichtbij Energievraag) waren in 2017 economisch iets minder belangrijk voor de visserij, waardoor de waarde van de overgebleven gebieden relatief iets hoger is.

Tabel 4.15 Directe, indirecte en totale productiewaarde ( $P W$; in $\mathrm{mln} . €$ ), toegevoegde waarde (TW; in $\mathrm{mln}$. $€$ ) en werkgelegenheid (in $1.000 \mathrm{fte}$ ) in visserij, voor 2017 en varianten in 2040/2050 a)

\begin{tabular}{|c|c|c|c|c|c|}
\hline & 2017 & Variant 1 & Variant 2 & Variant 3 & Variant 4 \\
\hline Direct & 120 & 100 & 97 & 99 & 101 \\
\hline Totaal & 168 & 140 & 136 & 139 & 142 \\
\hline \multicolumn{6}{|l|}{ TW } \\
\hline Indirect & 27 & 23 & 22 & 23 & 23 \\
\hline Totaal & 95 & 80 & 77 & 79 & 81 \\
\hline \multicolumn{6}{|l|}{ FTE } \\
\hline Direct & 0,9 & 0,8 & 0,8 & 0,8 & 0,8 \\
\hline
\end{tabular}

a) Alle waardes corresponderen met die van de waardes van de opengebleven gebieden in 2017 . 


\subsubsection{Aqua- en maricultuur}

Op dit moment is aqua-/maricultuur op het NCP klein (ongeveer $1 \mathrm{~km}^{2}$ ) en divers van karakter en heeft, in vergelijking tot de andere gebruiksfuncties op de Noordzee, geen economische waarde van betekenis (zie Tabel 4.16).

Tabel 4.16 Directe, indirecte en totale productiewaarde ( $P W$; in $\mathrm{mln}$. $€$ ), toegevoegde waarde (TW; in $\mathrm{mln}$. €) en werkgelegenheid (in $1.000 \mathrm{fte}$ ) in aqua-/maricultuur, voor 2017 en varianten in $2040 / 2050$

\begin{tabular}{|c|c|c|c|c|c|}
\hline & 2017 & Variant 1 & Variant 2 & Variant 3 & Variant 4 \\
\hline \multicolumn{6}{|l|}{ PW } \\
\hline Direct & 3 & 1.085 & 1.085 & 1.085 & 1.085 \\
\hline Totaal & 4 & 1.519 & 1.519 & 1.519 & 1.519 \\
\hline \multicolumn{6}{|l|}{ TW } \\
\hline Indirect & 0 & 56 & 56 & 56 & 56 \\
\hline Totaal & 0 & 195 & 195 & 195 & 195 \\
\hline \multicolumn{6}{|l|}{ FTE } \\
\hline Direct & 0,0 & 4,8 & 4,8 & 4,8 & 4,8 \\
\hline
\end{tabular}

De verwachting is dat de kweek van schelpdieren, microalgen en macroalgen (zeewier) de komende decennia zal toenemen (PBL, 2018), met als maximale verwachting een groei in zeewierteelt tot ongeveer $400 \mathrm{~km}^{2}$ in 2040/2050 (bron: RVO schatting, 2020) - i.e. een groeifactor van 400. Dit leidt tot een toename in productiewaarde (tot 1.519 miljoen euro), toegevoegde waarde (tot 195 miljoen euro) en werkgelegenheid (tot $8.100 \mathrm{fte}$ ). Daarmee zou aqua-/maricultuur een gebruiksfunctie met relatief groot economisch belang worden. Er zijn geen verschillen tussen varianten want ieder van de varianten voor de inrichting (van het Nederlands deel) van de Noordzee garandeert op dezelfde wijze, via ruimte voor aqua-/maricultuur in WOZ-zoekgebieden, dezelfde omvang van aqua-/maricultuur.

\subsubsection{Zandwinning}

Zandwinning op het NCP is, in vergelijking tot andere gebruiksfuncties, een relatief kleine economische sector op de Noordzee. In 2017 was de benodigde hoeveelheid zand 25 miljoen $\mathrm{m}^{3}$, goed voor een productiewaarde van 190+PM miljoen euro, een toegevoegde waarde van 45+PM miljoen euro en een werkgelegenheid van 330+PM fte (zie Tabel 4.17). De indirecte effecten zijn niet bekend en, dus, nemen we hiervoor PM-posten op.

Tabel 4.17 Directe, indirecte en totale productiewaarde (PW; in mln. $€$ ), toegevoegde waarde (TW; in $\mathrm{mln} . €$ ) en werkgelegenheid (in $1.000 \mathrm{fte}$ ) in zandwinning, voor 2017 en varianten in 2040/2050

\begin{tabular}{|c|c|c|c|c|c|}
\hline & 2017 & Variant 1 & Variant 2 & Variant 3 & Variant 4 \\
\hline \multicolumn{6}{|l|}{ PW } \\
\hline Direct & 190 & 300 & 300 & 300 & 300 \\
\hline Totaal & $190+\mathrm{PM}$ & $300+P M$ & $300+P M$ & $300+P M$ & $300+P M$ \\
\hline \multicolumn{6}{|l|}{ TW } \\
\hline Indirect & PM & PM & PM & PM & PM \\
\hline Totaal & $45+P M$ & $72+P M$ & $72+P M$ & $72+P M$ & $72+P M$ \\
\hline \multicolumn{6}{|l|}{ FTE } \\
\hline Direct & 0,3 & 0,5 & 0,5 & 0,5 & 0,5 \\
\hline
\end{tabular}


De verwachting is dat de vraag naar zand zal toenemen tot 40 miljoen $\mathrm{m}^{3}$ in 2040/2050 (bron: RWS schatting, 2020) - i.e. een groeifactor van 1,60. Dit leidt tot een toename in productiewaarde (tot 300+PM miljoen euro), toegevoegde waarde (tot 72+PM miljoen euro) en werkgelegenheid (tot $530+P M$ fte). Daarmee blijft zandwinning een gebruiksfunctie met relatief klein economisch belang. Er zijn geen verschillen tussen varianten want zandwinning vindt buiten de WOZ-zoekgebieden plaats.

\subsubsection{Globaal}

Globaal gezien is duidelijk dat, in 2017, olie- en gaswinning en scheepvaart de belangrijkste economische sectoren zijn op het NCP van de Noordzee (zie Figuur 4.1 tot en met Figuur 4.3). In termen van werkgelegenheid, echter, is ook de visserij een belangrijke sector. In totaal zijn de sectoren goed voor een productiewaarde van ruim 6.600 miljoen euro, een toegevoegde waarde van bijna 5.200 miljoen euro en een werkgelegenheid van ruim $12.000 \mathrm{fte}$.

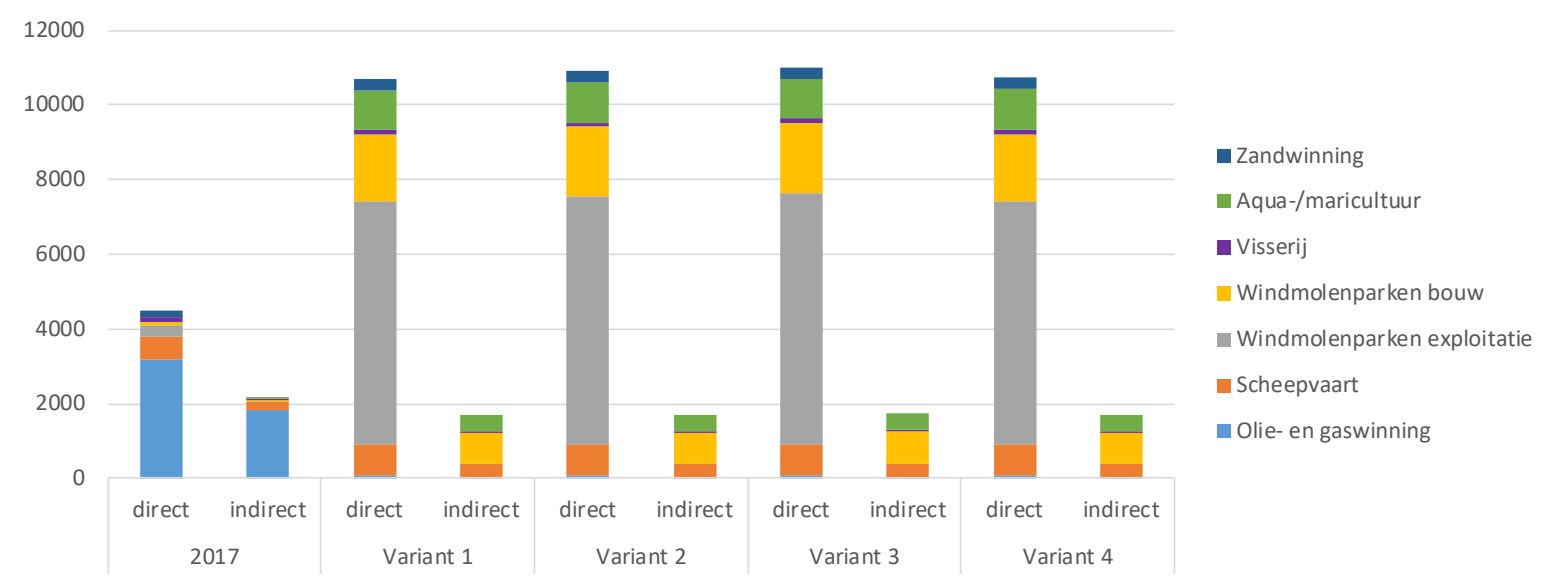

Figuur 4.1 Directe en indirecte productiewaarde (in m/n. €) per gebruiksfunctie, voor 2017 en varianten in 2040/2050

De varianten laten een grote verschuiving zien in het relatief economische belang van de verschillende gebruiksfuncties. Windmolenpark exploitatie, windmolenpark bouw en aqua-/maricultuur zouden gebruiksfuncties met een relatief groot economisch belang worden, scheepvaart en zandwinning behouden hun economisch belang, visserij laat een afname in economisch belang zien, en olie- en gaswinning zou een gebruiksfunctie met geen economische waarde van betekenis worden. Dit leidt tot een toename in productiewaarde (tot $\sim 12.500$ miljoen euro), een afname in toegevoegde waarde (tot $\sim 2.200$ miljoen euro) en een toename in werkgelegenheid (tot $\sim 25.600 \mathrm{fte}$ ). Deze cijfers zijn, echter, voor een groot deel afhankelijk van PM-posten en de aannames in windmolenpark exploitatie en bouw - met name het belang van deze sectoren voor de Nederlandse economie. Met betrekking tot werkgelegenheid zien we een gediversifieerd beeld ontstaan in de varianten, waarbij meerdere gebruiksfuncties substantieel bijdragen aan de werkgelegenheid op het NCP van Noordzee. 


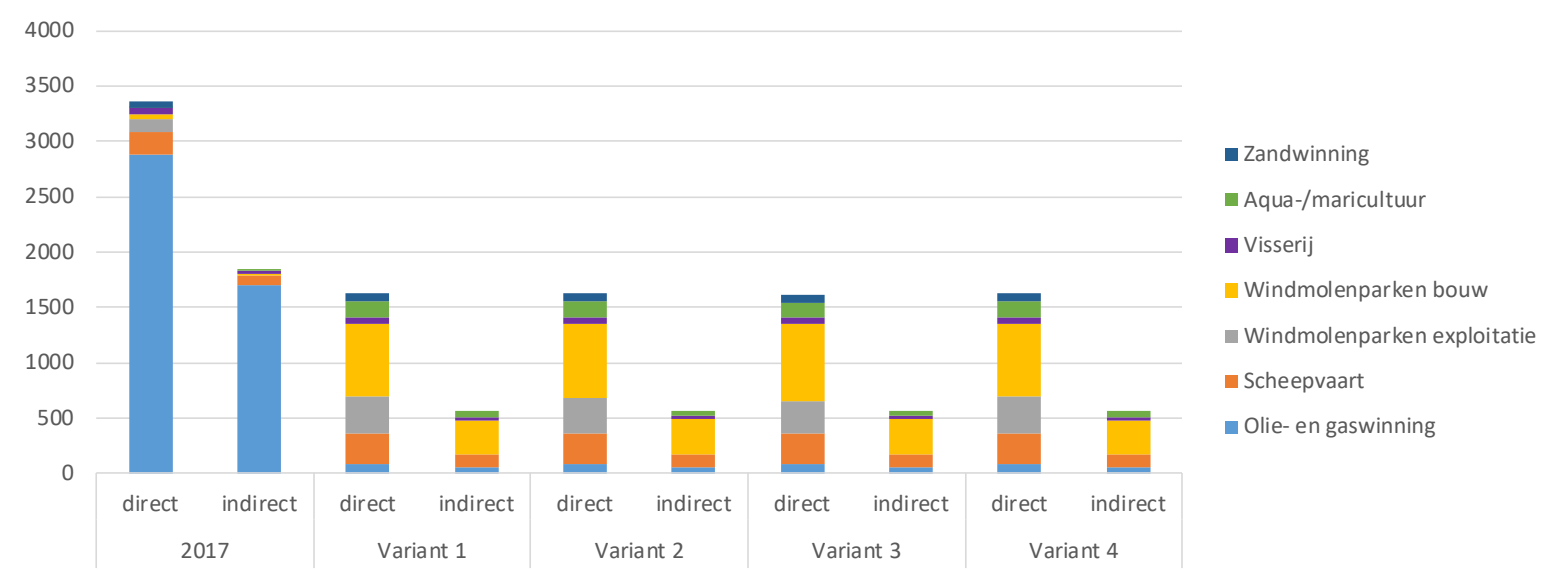

Figuur 4.2 Directe en indirecte toegevoegde waarde (in m/n. €) per gebruiksfunctie, voor 2017 en varianten in 2040/2050

De totale verschillen tussen de varianten zijn relatief klein, voor zowel productiewaarde (minder dan $3 \%$ verschil), toegevoegde waarde (minder dan $0,4 \%$ verschil) en werkgelegenheid (minder dan $2 \%$ verschil). Dit is met name het gevolg van het feit dat de verschillen tussen de verschillende varianten klein zijn - i.e. slechts variatie in de locatie van WOZ-zoekgebieden met relatief kleine (ten opzichte van totale waardes van alle gebruiksfuncties) verschillen in bouwkosten, rendementsverschillen en aanlandings-kosten (kabels) van de WOZ-zoekgebieden die samen $28 \mathrm{GW}$ vormen. Op basis van toegevoegde waarde en werkgelegenheid is er een lichte voorkeur voor Variant 2 (Mix Energiehubs).

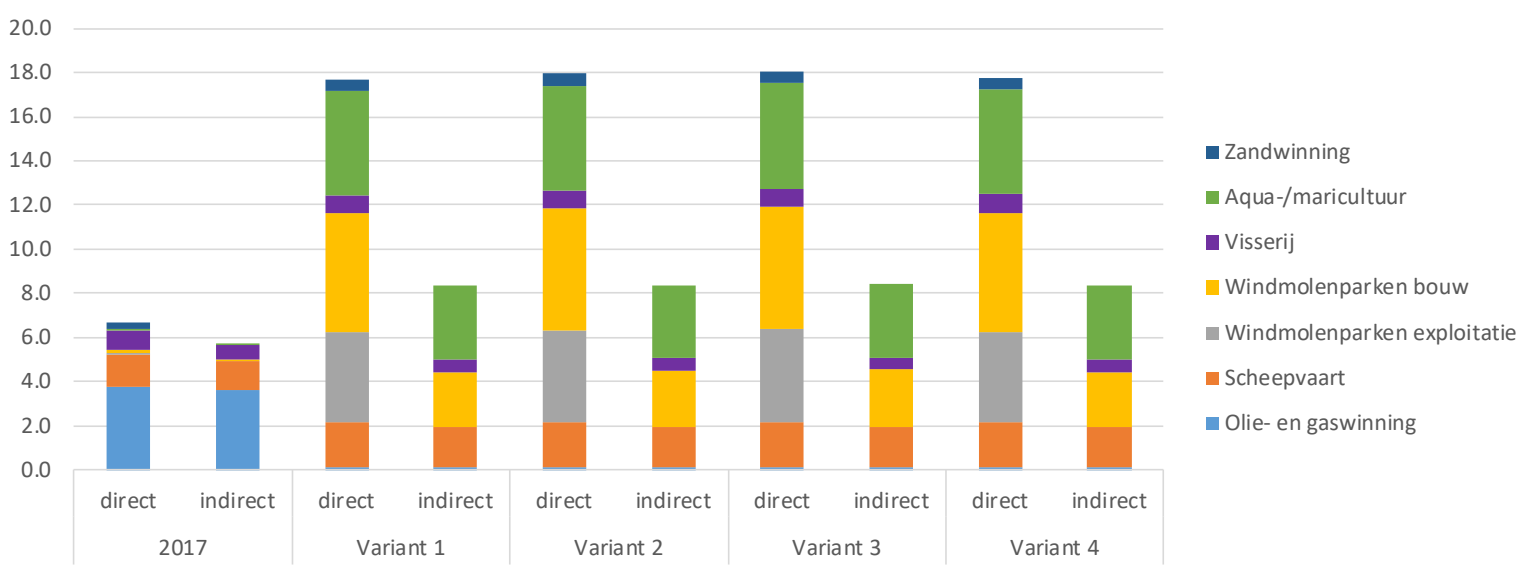

Figuur 4.3 Directe en indirecte werkgelegenheid (in $1.000 \mathrm{fte}$ ) per gebruiksfunctie, voor 2017 en varianten in 2040/2050

\subsubsection{Natuur/biodiversiteit effecten}

De impact per gebruiksfunctie in referentie (2017) en varianten (2040/2050) staat per ecosysteem component weergegeven voor vogels (Sectie 4.2.2.1), vissen (Sectie 4.2.2.2), zeezoogdieren (Sectie 4.2.2.3) en habitats (Sectie 4.2.2.4). De totale impact door alle gebruiksfuncties op ecosysteem componenten (vogels, vissen, zeezoogdieren en habitats) staat weergegeven in referentie en varianten (Sectie 4.2.2.5).

\subsubsection{Vogels}

De impact op vogels (uitgedrukt in \% aangetast) door alle gebruiksfuncties in referentie en varianten per ecosysteem component staat weergegeven in Figuur 4.4. De impact op vogels in de huidige situatie (referentiejaar) is voornamelijk gerelateerd aan visserij en windenergie. Bij alle varianten neemt de totale impact toe ten opzichte van 2017. Dit is voornamelijk het gevolg van de ontwikkeling van windenergie. De ontwikkeling van aquacultuur (zeewierkweek) veroorzaakt ook meer impact op 
vogels, maar deze toename is marginaal. De impact door visserij neemt iets af. Het verschil in impact tussen de varianten is zeer gering; bij variant Zuid is de impact door windenergie iets minder. Dit komt doordat het oppervlak aan windmolenparken van variant Zuid kleiner is dan de overige varianten.

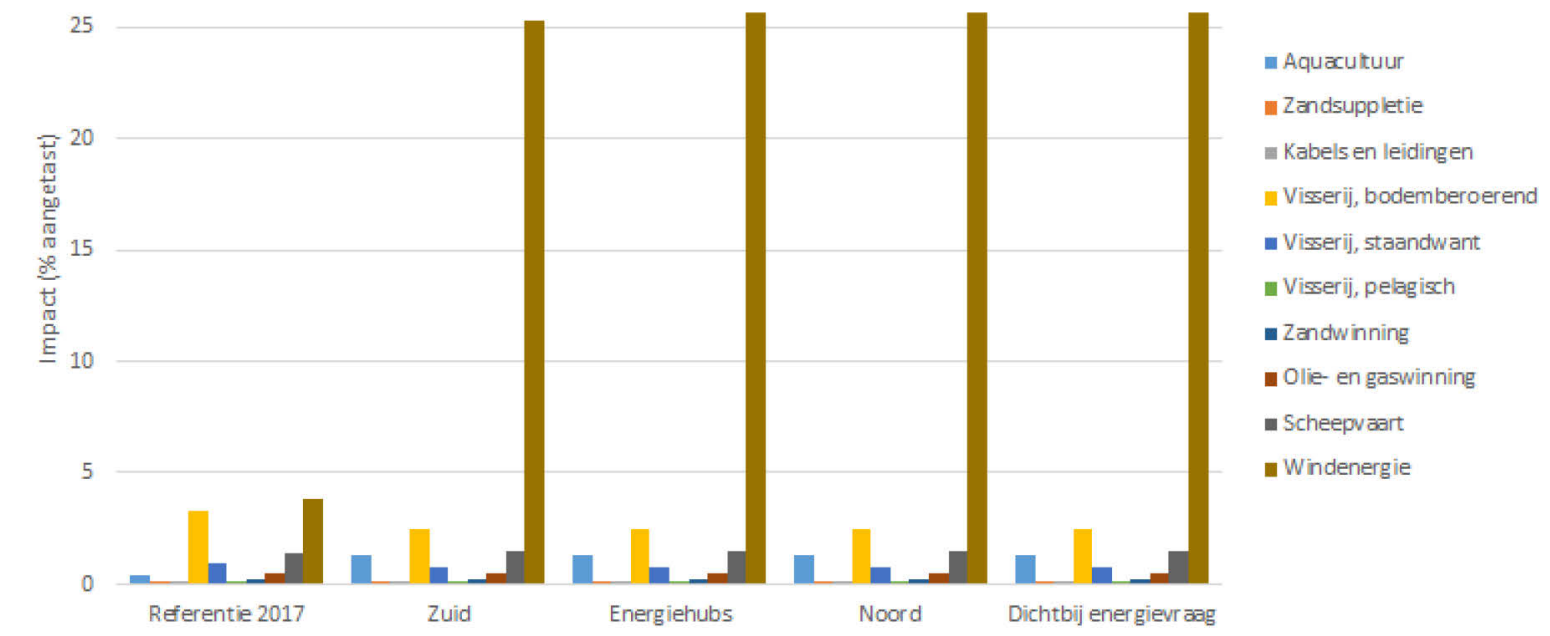

Figuur 4.4 Totale impact op vogels per gebruiksfunctie in referentie (2017) en varianten op het toekomstscenario 2040/2050 (Zuid; Energiehubs; Noord; Dichtbij energievraag).

\subsubsection{Zeezoogdieren}

Figuur 4.5 laat zien dat de impact op zeezoogdieren in de huidige situatie (referentiejaar) voornamelijk gerelateerd is aan visserij en een combinatie aan overige gebruiksfuncties. De varianten laten een vergelijkbaar beeld zien als bij vogels. Bij alle varianten neemt de totale impact toe ten opzichte van het referentiejaar, wat voornamelijk het gevolg is van de ontwikkeling van windenergie. Ook voor zeezoogdieren is de impact door visserij lager bij de varianten dan in het referentiejaar. Wat betreft het verschil in totale impact op zeezoogdieren tussen de varianten is, net als bij vogels, de impact bij variant Zuid iets minder ten opzichte van de impact bij de overige varianten.

12

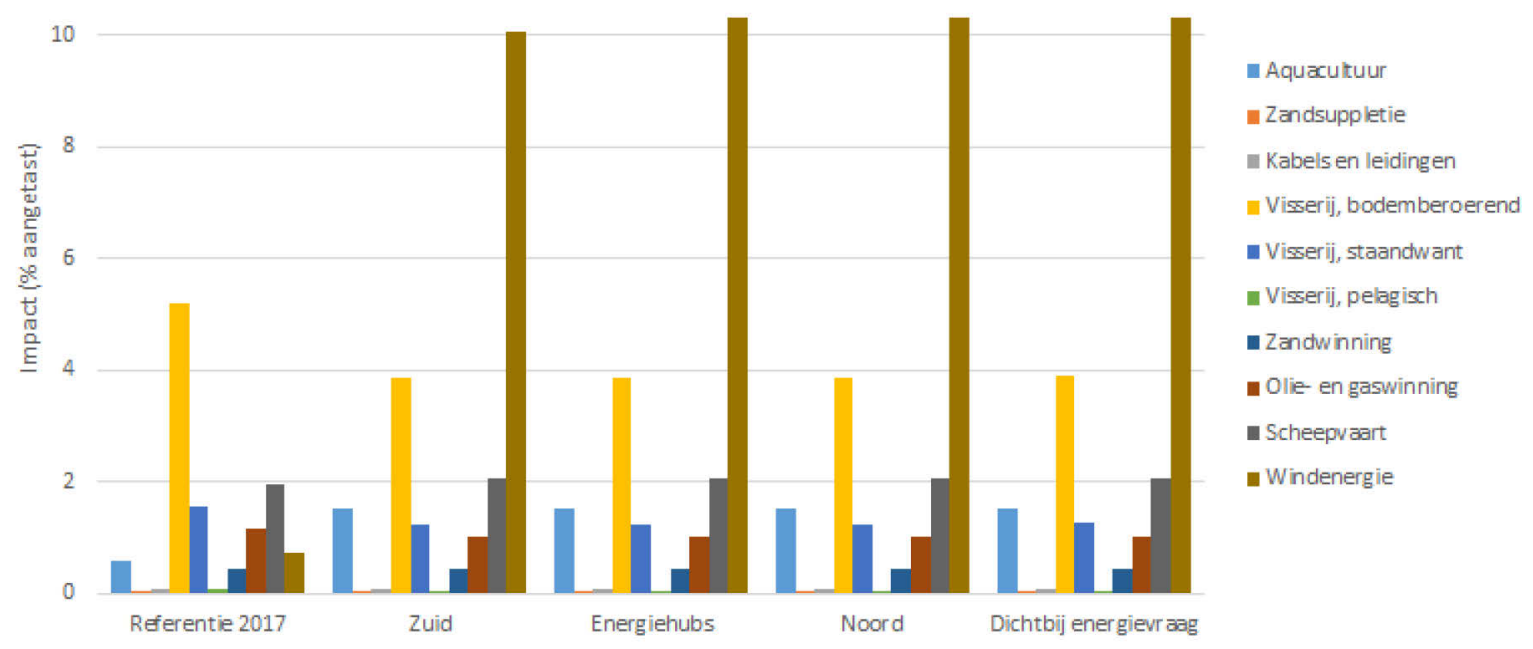

Figuur 4.5 Totale impact op zeezoogdieren per gebruiksfunctie in referentie (2017) en varianten op het toekomstscenario 2040/2050 (Zuid; Energiehubs; Noord; Dichtbij energievraag). 


\subsubsection{Vissen}

In Figuur 4.6 is te zien dat de impact op vissen (uitgedrukt in percentage aangetast) in de huidige situatie (referentiejaar) vrijwel geheel gerelateerd is aan visserij. Anders dan bij vogels en zeezoogdieren, is de impact op vissen bij de varianten ook grotendeels gerelateerd aan visserij. De impact door windenergie is, ook bij de varianten, zeer klein ten opzichte van de impact door visserij. Wat betreft de totale impact op vissen is er geen verschil waarneembaar tussen de varianten.

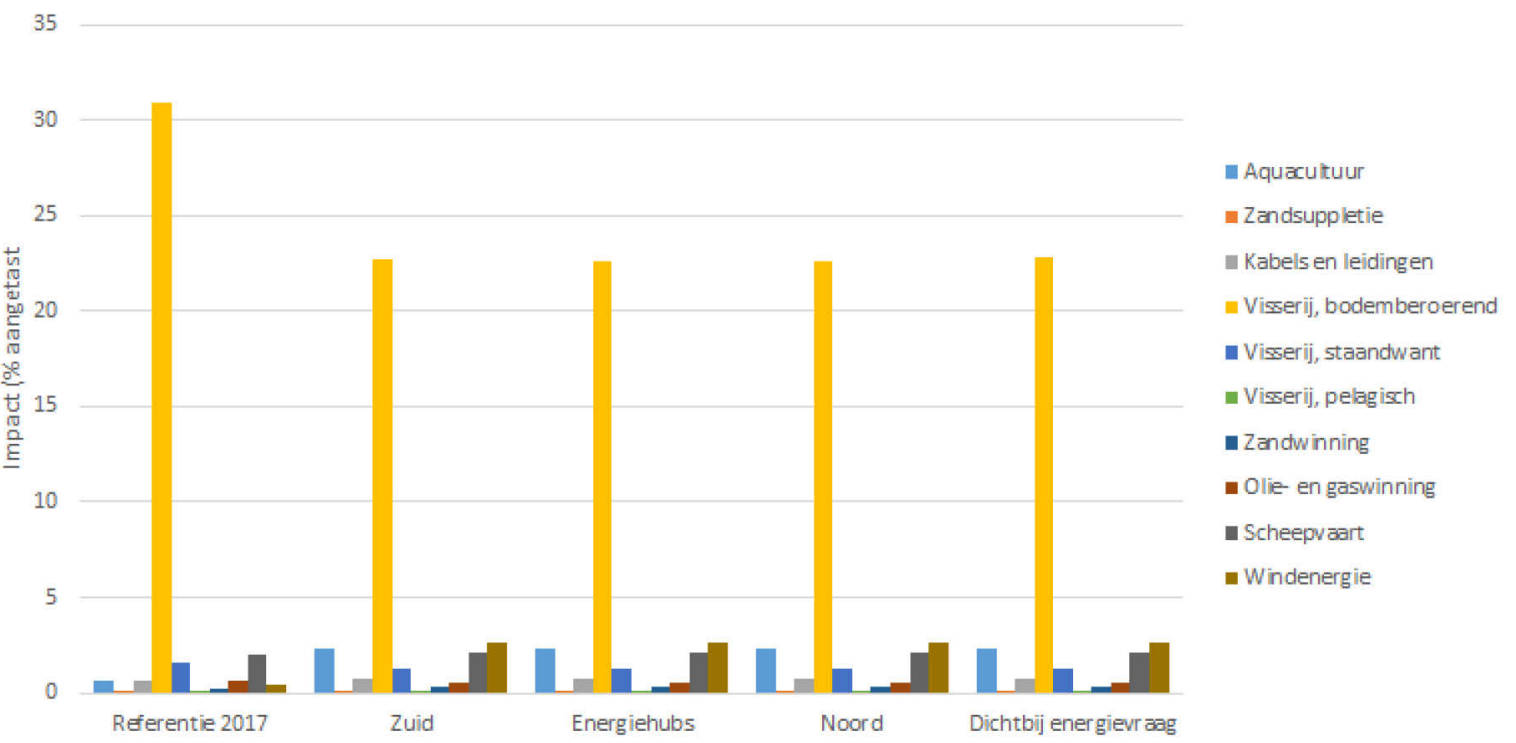

Figuur 4.6 Totale impact op vissen per gebruiksfunctie in referentie (2017) en varianten op het toekomstscenario 2040/2050 (Zuid; Energiehubs; Noord; Dichtbij energievraag)

\subsubsection{Habitats}

De impact op habitats (uitgedrukt in percentage aangetast, zie Figuur 4.7) is, net als bij vissen, voornamelijk gerelateerd aan visserij. Ook bij de varianten blijft visserij de meeste impact veroorzaken. Daarnaast speelt bij de varianten aquacultuur een relatief grote rol, onder andere door verandering in habitat structuur, introductie van andere soorten en verandering in stromingen. Het aandeel van windenergie aan de totale impact is minder van belang.

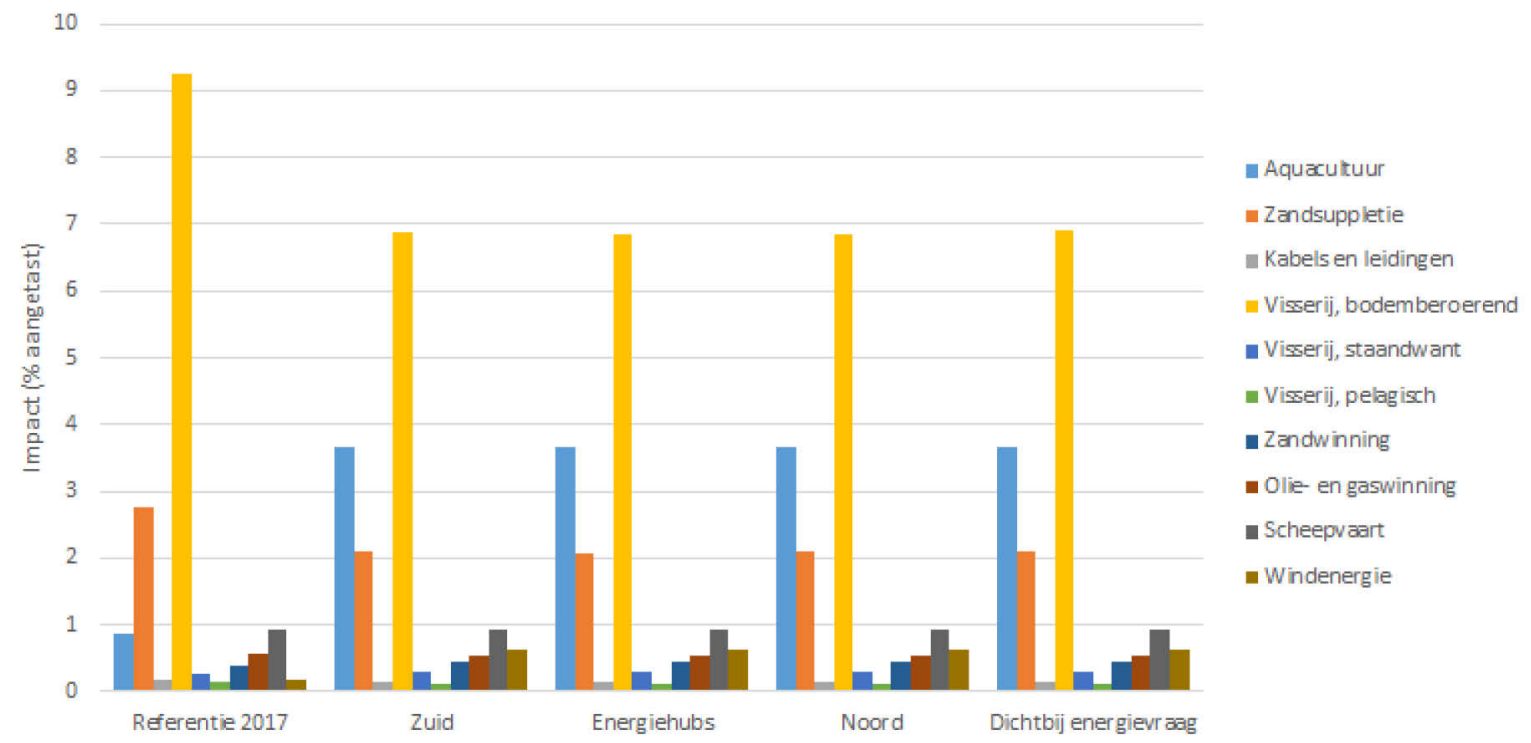

Figuur 4.7 Totale impact op habitats per gebruiksfunctie in referentie (2017) en varianten op het toekomstscenario 2040/2050 (Zuid; Energiehubs; Noord; Dichtbij energievraag) 


\subsubsection{Globaal}

De totale impact op vogels, vissen, zeezoogdieren en habitats (uitgedrukt in percentage aangetast) door alle gebruiksfuncties in referentie en varianten per ecosysteem component staat weergegeven in Figuur 4.8. Voor vogels en zeezoogdieren is de totale impact toegenomen bij de varianten ten opzichte van het referentiejaar. Voor vissen en habitats is de totale impact bij de varianten afgenomen ten opzichte van de referentie. Er zijn nauwelijks verschillen in impact waarneembaar tussen de varianten. Zoals eerder beschreven zijn de varianten in de impactanalyse opgenomen op basis van oppervlakte van de gebruiksfuncties en deze zijn vrijwel gelijk bij alle varianten.

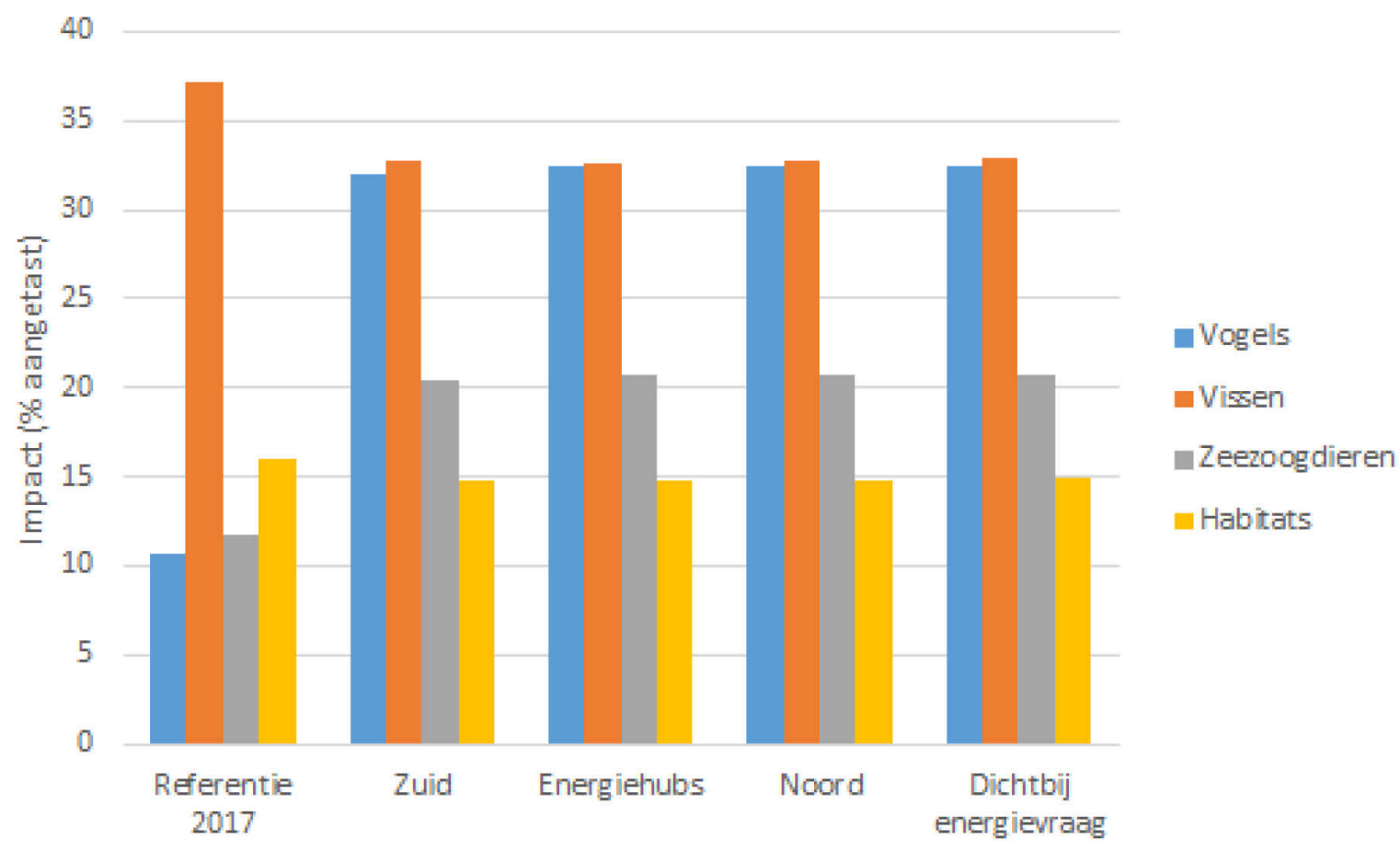

Figuur 4.8 Totale impact per ecosysteem component (vogels; vissen; zeezoogdieren; habitats) door alle gebruiksfuncties in referentie (2017) en varianten op het toekomstscenario 2040/2050 (Zuid; Energiehubs; Noord; Dichtbij energievraag). 


\section{Discussie, conclusies en aanbevelingen}

\section{$5.1 \quad$ Discussie}

In verschillende werksessies met stakeholders en vertegenwoordigers van het Rijk is verkend welke wind-op-zee (WOZ-)zoekgebieden in aanmerking zouden kunnen komen - daarbij rekening houdend met de eisen uit het Noordzee-akkoord en de mogelijkheden die potentiële gebieden bieden ten aanzien van internationale (stroom)connecties en waterstofproductie en de ideeën die aangedragen zijn door de visserij. Op basis van dit proces zijn acht gebieden geïdentificeerd als mogelijke WOZzoekgebieden, met name: op de grens met Norfolk Boreas (WOZ1), ten noorden van IJmuiden-ver (WOZ2), ten noordwesten van IJmuiden-ver (WOZ3), Defensie oefengebied ten noorden van de Wadden (WOZ4), driehoek op grens met Duitsland (WOZ5), gebied ten noorden van Friese Front (WOZ6), ten oosten van Klaverbank (WOZ7) en ten noordwesten van Texel (WOZ8).

\subsubsection{Wind-op-zee zoekgebieden}

Windmolenpark exploitatie is het meest efficiënt in, respectievelijk, wind-op-zee zoekgebied WOZ3, WOZ5, WOZ4 en WOZ6; windmolenpark exploitatie is het minst efficiënt in WOZ7. De efficiëntie is, met name, afhankelijk van de bouwkosten, het rendement van de windmolenparken en de kabel aanlandingskosten. Windmolenpark bouw is het meest lucratief in, respectievelijk, wind-op-zee zoekgebied WOZ7, WOZ6 en WOZ1; het laagste in WOZ4. In tegenstelling tot windmolenpark exploitatie, leiden juist hogere bouwkosten tot een hogere toegevoegde waarde in windmolenpark bouw. De rentabiliteit van windmolenpark exploitatie is, echter, bepalend voor het al dan niet exploiteren van windmolenparken op zee. Visserij ondervindt de grootste negatieve consequenties in, respectievelijk, WOZ6, WOZ1 en WOZ5. Met name Boomkor/sumwing/puls visserij en Bordentrawls/twinrig ondervinden de grootste negatieve consequenties.

Expert inschattingen per soortgroep (Jongbloed et al., 2020) geven aan dat: i) voor zeevogels de minste effecten worden verwacht voor WOZ1, WOZ2, WOZ6 en WOZ8, en de meeste voor WOZ3, WOZ5 en WOZ7; ii) voor vissen de inschatting neutraal is voor alle gebieden; iii) voor zeehonden de potentiële effecten groot zijn voor (bijna) alle WOZ-zoekgebieden (voor WOZ3, WOZ6 en WOZ7 zijn de effecten onduidelijk); iv) voor bruinvis de minste effecten worden verwacht voor WOZ1, en de meeste effecten voor WOZ2, WOZ3, WOZ4 en WOZ8 (voor de WOZ5, WOZ6 en WOZ7 zijn de effecten onduidelijk); v) voor vleermuizen de meeste effecten worden verwacht voor WOZ1 en WOZ2 (voor de overige gebieden zijn effecten onduidelijk); en vi) voor benthos de meeste kansen worden verwacht voor WOZ4, en de minste kansen voor WOZ7.

\subsubsection{Inrichtingsvarianten}

De vier gedefinieerde varianten voor de inrichting van de Noordzee onderscheiden zich in globale locatie van de WOZ-zoekgebieden, met gebieden meer in het zuiden (Combinatie Zuid), een mix van energiecluster in zuiden en noorden (Mix Energiehubs), met gebieden meer in het noorden (Combinatie Noord) en met gebieden met kleinere afstand tot de kust (Dichtbij Energievraag). Uitgangspunt bij de varianten waren een vrijwel volledige afname in olie- en gaswinning, een $39 \%$ toename in scheepvaart, gelijkblijvende scheepvaartveiligheid, een groei in windmolenparken van $11,5 \mathrm{GW}$ tot 2030 en nog eens 28 GW tot 2040/2050, een opschaling van aqua-/maricultuur tot $400 \mathrm{~km}^{2}$ (medegebruik in windmolenparken), een $60 \%$ toename in zandwinning, een uitbreiding van natuurgebieden volgens het Noordzee-akkoord (versie april 2020) en een toe-/afname in visgebied afhankelijk van de ontwikkelingen in andere gebruiksfuncties. 
De varianten laten een grote verschuiving zien in het relatief economische belang van de verschillende gebruiksfuncties tussen 2017 en 2040/2050. Windmolenpark exploitatie, windmolenpark bouw en aqua-/maricultuur zouden gebruiksfuncties met een relatief groot economisch belang worden, scheepvaart en zandwinning behouden hun economisch belang, visserij laat een afname in economisch belang zien, en olie- en gaswinning zou een gebruiksfunctie met geen economische waarde van betekenis worden. Met betrekking tot werkgelegenheid zien we een gediversifieerd beeld ontstaan in de varianten, waarbij meerdere gebruiksfuncties substantieel bijdragen aan de werkgelegenheid op het NCP van Noordzee.

De impact (uitgedrukt in \% aangetast) van de varianten op vogels, vissen, zeezoogdieren en habitats laat zien dat voor vogels en zeezoogdieren de totale impact is toegenomen terwijl voor vissen en habitats de totale impact is afgenomen. De toegenomen impact op vogels en zeezoogdieren is een gevolg van de ontwikkeling van windenergie. De afgenomen impact op vissen en habitats is, met name, gerelateerd aan de afname in visserij en toenamen in habitat oppervlakte als gevolg van de sluiting voor gebruiksfuncties van windmolenparken en natuurgebieden.

De verschillen in economische en natuur/biodiversiteit effecten tussen de varianten zijn relatief klein. Dit is met name het gevolg van het feit dat de verschillen tussen de varianten klein is - i.e. slechts variatie in de locatie van WOZ-zoekgebieden. Voor de economische effecten betekent dit dat er relatief kleine (ten opzichte van totale waardes van alle gebruiksfuncties) verschillen in bouwkosten, rendementsverschillen en aanlandingskosten (kabels) zijn van de WOZ-zoekgebieden die samen $28 \mathrm{GW}$ vormen. De economische analyse duidt op een lichte voorkeur voor Variant 2 (Mix Energiehubs). Voor de natuur/biodiversiteit effecten betekent dit dat er nauwelijks verschillen zijn in oppervlaktes van de gebruiksfuncties op het NCP van de Noordzee, terwijl de CEA-methode in zijn huidige vorm wel de oppervlakte maar niet de locatie impacts van gebruiksfuncties kan duiden. De natuur Expert opinion analyse (Jongbloed et al., 2020) duidt, ook, op een lichte voorkeur voor Variant 2 (Mix Energiehubs).

\subsection{Conclusies}

Op basis van deze resultaten zijn er noch WOZ-zoekgebieden noch varianten aan te wijzen die het duidelijk beter doen. Voor alle WOZ-zoekgebieden en varianten lijken er geen win-win kandidaten te zijn - i.e. iedere van de onderzochte keuzemogelijkheden hebben negatieve consequenties, zij het voor de economie, de werkgelegenheid of de natuur. Voor alle varianten geldt dat ze, in vergelijking tot de huidige situatie, leiden tot een grote verschuiving in het relatief economische belang van de verschillende gebruiksfuncties alsmede een grote impact op de natuur en biodiversiteit (vogels en zeezoogdieren). Er bestaat onvoldoende kennis om de impact op deze soortgroepen eenduidig te kunnen kwantificeren per WOZ zoekgebied. Aan de hand van de expert inschattingen voor alle soortgroepen tezamen, inclusief kansen voor rifbouwende soorten, is er wel een rangorde op volgorde van afnemende geschiktheid van WOZ-zoekgebieden en varianten voor natuur en biodiversiteit aan te geven, maar de betrouwbaarheid van dat resultaat is beperkt vanwege belangrijke kennislacunes.

\subsection{Aanbevelingen}

Deze studie is uitgevoerd op basis van bestaande gegevens (d.d. juni 2020), gecombineerd met de uitgangspunten per WOZ zoekgebied en variant. Een aantal posten kon echter niet of niet goed worden gekwantificeerd; hiervoor zijn PM-posten opgenomen. Met het opnemen van deze PM-posten vallen de cumulatieve cijfers uit de samenvattende tabellen lager uit dan daadwerkelijk zou mogen worden verwacht. Daarnaast omvatten de meegenomen indirecte effecten de aanvoer van goederen en diensten voor gebruiksfuncties op zee, maar niet de indirecte effecten die ontstaan als gevolg van afvoer/verwerking van goederen en diensten vanuit gebruiksfuncties op zee. Ook hiermee vallen de cumulatieve cijfers lager uit dan daadwerkelijk zou mogen worden verwacht. Daarom dienen de berekende getallen in deze verkenning gezien te worden als een indicatie van de ondergrens voor de 
mogelijke economische effecten en geeft deze studie inzicht in de richting van de economische effecten alsmede de contouren van de mogelijke omvang van deze effecten.

De belangrijkste bron om de indirecte effecten te bepalen is de Maritieme Monitor (Ecorys, 2018). Hierin zijn op basis van input-outputmodellen berekeningen gemaakt voor de indirecte effecten per maritieme sector. Daarbij worden de indirecte effecten in deze bron voor de huidige situatie met een bepaalde verhouding weergegeven. Die verhoudingen hebben wij ook in dit rapport toegepast en nemen aan dat deze verhoudingen ongewijzigd blijven. In hoeverre deze verhoudingen nog hetzelfde zouden zijn in 2040/2050 staat, echter, niet in die bron vermeld. In de Maritieme Monitor wordt ook aangegeven dat alle individuele indirecte effecten niet per definitie kunnen worden opgeteld om daarmee het totaal aan indirecte effecten te berekenen. De reden hiervoor is dat er ook sprake is van onderlinge leveringen tussen sectoren binnen de clusters en het feit dat een aantal 'subsectoren' soms in twee sectoren wordt meegeteld. Het totaal van de indirecte effecten voor de gehele maritieme cluster (de focus van de Maritieme Monitor) ligt dus lager dan de som van de afzonderlijke sectoren.

Om de economische effecten voor WOZ-zoekgebieden en varianten door te rekenen hebben we in deze studie veel gebruikgemaakt van aannames, uitgangspunten en cijfers gebaseerd op de door ons geraadpleegde bronnen. Gezien de beschikbare informatie en de inherente onzekerheid die hoort bij toekomstscenario's, kunnen de in deze studie gepresenteerde getallen en berekeningen daarom alleen worden beschouwd als aanduiding van ordegroottes, relatieve verschillen en verwachte ontwikkelingen in en tussen de varianten.

Aangezien windenergie op zee in 2040/2050 de grootste economische gebruiksfunctie is, zal een afwijking van de aannames in de berekeningen voor deze gebruiksfunctie grote consequenties hebben voor de totaalresultaten. Zo zullen, bijvoorbeeld, aannames over het rendement, de prijs (kWh eurocent) en de relatieve bijdrage van de activiteit aan de Nederlandse economie, grote consequenties voor de totaalresultaten hebben. Voor andere gebruiksfuncties zijn de aannames met meer onzekerheid omgeven, maar de economische omvang van deze gebruiksfuncties is in 2040/2050 kleiner en daarmee het effect op het totaalresultaat.

Voor de gebruiksfunctie visserij is uitsluitend berekend wat de huidige (2017) waarde is van de gebieden die in varianten in (2040/2050) niet meer bevist kunnen worden. De varianten geven echter geen toekomstvoorspelling: het is onzeker wat vissers doen met het sluiten van de gebieden en gezien de ontwikkelingen in de toekomst. De daadwerkelijke effecten in 2040/2050 zullen afhangen van in hoeverre de vissers zich verplaatsen naar andere gebieden, mogelijke saneringsregelingen, Brexit, natuurbehoud en andere WOZ ontwikkeling op de Noordzee. Bovendien is de economische impact van de in de varianten geschetste ontwikkelingen op de visserij en de gevolgen hiervan voor de visserijcluster (inclusief handel \& verwerking) en visserijgemeenschappen niet meegenomen.

De uitkomsten van de CEA methodiek kunnen met de huidige kennis nog niet in absolute termen worden gegeven maar, op $z^{\prime} n$ best, in termen van ordening (dus groter/kleiner dan maar niet hoeveel of in welke mate) en daarnaast dus ook in cumulatieve zin (dus niet ruimtelijk gespecificeerd). Dit laatste wil zeggen dat er wel aangegeven kan worden wat, gemiddeld gezien, de effecten zouden zijn van een toe- of afname van een gebruiksfunctie op de Noordzee als geheel, maar niet als functie van een specifiek gebied. Een nadere ruimtelijke specificering van deze effecten per WOZ-zoekgebied binnen de inrichtingsvarianten is wel mogelijk, maar wegens de beperkte tijd en budget niet binnen deze studie. Ook al is daarmee in deze studie de mate van detail en ruimtelijke differentiatie lager dan wat in de praktijk mogelijk is, toch kan de hierboven beschreven aanpak gebruikt worden om, net als bij de economische analyse, een idee te krijgen van de richting van de ecologische effecten van de verschillende inrichtingsvarianten in cumulatieve zin.

In het huidige project is er wel een ruimtelijke differentiatie in de analyse van de WOZ-zoekgebieden toegepast door een aantal experts te consulteren (Jongbloed et al., 2020). Hiermee is een kwalitatieve beoordeling uitgevoerd waarmee de WOZ-zoekgebieden alsmede de varianten zijn gerangschikt naar geschiktheid op basis van de te verwachten impact op de soorten als maat voor natuur en biodiversiteit. Er zijn door deze experts echter een aantal belangrijke kennislacunes geformuleerd. De experts hebben aangegeven welke type informatie nodig is om een inschatting van de risico's van 
windmolenparken op zee in de toekomst goed te kunnen maken. Daarnaast hebben de experts ook een aantal suggesties gegeven voor het identificeren van WOZ-zoekgebieden. Het kan worden aanbevolen de nieuwe gegevens uit lopend en nieuw onderzoek met bestaande gegevens te integreren in een CEA tool waarmee de impact van bestaande en toekomstige menselijke activiteiten op de Noordzee kunnen worden gekwantificeerd en toegepast voor ruimtelijke ordening op zee. 


\section{Referenties}

Algemene Rekenkamer, 2018. Focus op kosten windenergie op zee. Online:

https://www.rekenkamer.nl/publicaties/rapporten/2018/09/27/focusonderzoek-kosten-vanwindparken-op-zee.

BLIX, 2020. Study into Levelized Cost of Energy of seven new wind zones and IJmuiden Ver. Report WOZ2180100 (Draft 17-04-2020), BLIX Consultancy, Utrecht, Nederland. 41 pp.

Borgwardt, F., L. Robinson, D. Trauner, et al., 2019. Exploring variability in environmental impact risk fromhuman activities across aquatic ecosystems. Science of the Total Environment, 652: 1396-1408.

CBS, 2016. Economic description of the Dutch North Sea and Coast: 2005, 2010, 2014. Online: https://www.cbs.nl/-/media/_pdf/2017/22/170530\%20economic-description-of-the-dutch-northsea-and-coast-2005-2010-2014.pdf.

Deetman, B., A.Y. Eweg, J.A.E. van Oostenbrugge, A. Mol, K.G. Hamon en N.A. Steins, 2020. Inzicht in de sociaal-economische waarde van de zoekgebieden windenergie op de Noordzee 2030-2050 voor de Nederlandse visserij. Rapport 2020-125, Wageningen Economic Research, Wageningen, Nederland. URL: https://doi.org/10.18174/536640.

Ecorys, 2017. Maritieme Monitor 2017. Online: https://www. maritiemland.nl/download-digitale-versierapport-maritieme-monitor-2017/.

Ecorys, 2018. Maritieme Monitor 2018. Online: http://www. maritiemland.nl/downloadlink. php?file=wp-content/uploads/2018/11/NML-v.4-Eindrapportage-Maritieme-Monitor-2018-2410-2018.pdf.

EIB, 2016. Energieakkoord. Effecten van de energietransitie op de inzet en kwaliteit van arbeid. Online:

https://www.energieakkoordser.nl/ /media/files/energieakkoord/nieuwsberichten/2016/inzetkwaliteit-arbeid-eib.ashx.

Hintzen, N.T., F. Bastardie, D.J. Beare, G.J. Piet, C. Ulrich, N. Deporte, J. Egekvist en H. Degel, 2012. VMStools: Open-source software for the processing, analysis and visualisation of fisheries logbook and VMS data. Fisheries Research, 115-116: 31-43.

Jongbloed, R.H., J.E. Tamis, P. de Vries en G.J. Piet, 2019. NatuurVerkenning voor de Noordzee: voorbeeld uitwerking van een Noordzee bijdrage aan de Natuurverkenningen. Rapport C055/19, Wageningen Marine Research, Den Helder, Nederland. URL: https://doi.org/10.18174/479145.

Jongbloed, R.H., J.E. Tamis en J. Steenbergen, 2020. Expert inschatting van nieuwe windparkzoekgebieden op de Noordzee voor verschillende soortgroepen. Rapport C097/20, Wageningen Marine Research, Den Helder, Nederland. URL: https://doi.org/10.18174/533540.

Knights, A.M., G.J. Piet, R.H. Jongbloed, et al., 2015. An exposure-effect approach for evaluating ecosystem-wide risks from human activities. ICES Journal of Marine Science, 72(3): 1105-1115.

Knol, E. en J. Baken, 2018. Invulling groeiende arbeidsvraag in offshore windsector vanuit offshore olie- en gassector. Online:

https://www.topsectorenergie.nl/sites/default/files/uploads/Wind\%20op\%20Zee/Documenten/201 801_RAP_Invulling-groeiende-arbeidsvraag-in-offshore-windsector-vanuit-offshore-olie-engas.pdf.

NML, 2018. Jaarverslag 2017 - Trots op de maritieme sector. On-line: https://www. maritiemland.nl/?post_type=page\&p=106252.

PBL, 2018. De toekomst van de Noordzee - De Noordzee in 2030 en 2050: een scenariostudie. Online: https://www.pbl.nl/sites/default/files/cms/publicaties/pbl-2018-toekomst-van-de-noordzee2728.pdf.

PBL, 2019. Achtergronden bij de Toekomst van de Noordzee: onderliggende gegevens en aannames. Online: https://www.pbl.nl/sites/default/files/cms/publicaties/pbl-2019-achtergronden-bij-detoekomst-van-de-noordzee_3177.pdf.

PROMOTION, 2016. Deliverable 1.3: Synthesis of available studies on offshore meshed HVDC grids. Deliverable 1.3, Progress on Meshed HVDC Offshore Transmission Networks (PROMOTioN), EUHorizon 2020. 143 pp. 
PWC, 2018. De economische bijdrage van windenergie op zee. Online:

https://www.rijksoverheid.nl/documenten/rapporten/2018/08/31/de-economische-bijdrage-vanwindenergie-op-zee.

Rijksoverheid, 2019. XII Infrastructuur en Waterstaat Rijksbegroting 2019. Online:

https://www.rijksoverheid.nl/documenten/begrotingen/2018/09/18/xii-infrastructuur-enwaterstaat-rijksbegroting-2019.

Streng, M., B. Kuipers en E. Becker, 2018. Trends en ontwikkelingen richting 2030 en de impact op het maritiem transport in de Noordzee. Erasmus Centre for Urban, Port and Transport Economics (UPT), Erasmus Universiteit Rotterdam, Rotterdam, Nederland. 27 pp.

Strietman, W.J., A.J. Reinhard, A.T. De Blaeij en B.W. Zaalmink, 2017. The cost of degradation of the Dutch North Sea environment; A study into the costs of avoiding degradation and the applicability of the Ecosystem Services approach. Wageningen, Wageningen Economic Research, Report 2018-015. Online: http://edepot.wur.nl/432050.

Strietman, W.J., K.G. Hamon en A. Mol, 2019. De economische effecten van twee toekomstscenario's voor de Noordzee. Rapport 2019-080, Wageningen Economic Research, Wageningen, Nederland. Online: https://doi.org/10.18174/495958.

UEPG, 2018. Estimates of production data. Online: http://www.uepg.eu/statistics/estimates-ofproduction-data/data-2016.

Van Dijk, W. en J.R. van der Schoot, 2015. An economic model for offshore cultivation of macroalgae. Report WP2A7.11, EnAlgae project, Swansea, UK. 21 pp. 
Wageningen Economic Research Postbus 29703

2502 LS Den Haag

T 0703358330

Ecommunications.ssg@wur.nl

www.wur.nl/economic-research

Wageningen Economic Research RAPPORT

2021-063
De missie van Wageningen University \& Research is 'To explore the potential of nature to improve the quality of life'. Binnen Wageningen University \& Research bundelen Wageningen University en gespecialiseerde onderzoeksinstituten van Stichting Wageningen Research hun krachten om bij te dragen aan de oplossing van belangrijke vragen in het domein van gezonde voeding en leefomgeving. Met ongeveer 30 vestigingen, 6.800 medewerkers (6.000 fte) en 12.900 studenten behoort Wageningen University \& Research wereldwijd tot de aansprekende kennisinstellingen binnen haar domein. De integrale benadering van de vraagstukken en de samenwerking tussen verschillende disciplines vormen het hart van de unieke Wageningen aanpak. 



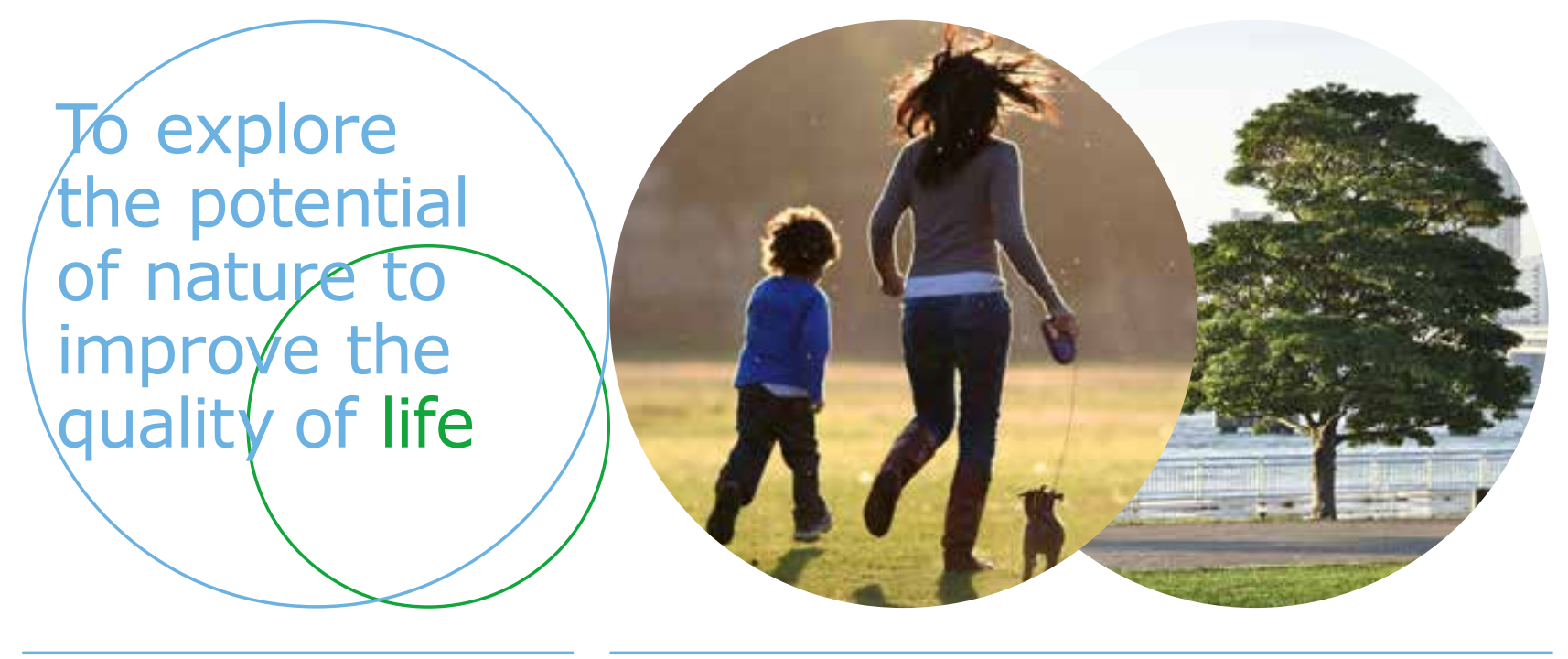

Wageningen Economic Research Postbus 29703

2502 LS Den Haag

T 0703358330

E communications.ssg@wur.nl www.wur.nl/economic-research

Rapport 2021-063

ISBN 978-94-6395-853-0
De missie van Wageningen University \& Research is 'To explore the potential of nature to improve the quality of life'. Binnen Wageningen University \& Research bundelen Wageningen University en gespecialiseerde onderzoeksinstituten van Stichting Wageningen Research hun krachten om bij te dragen aan de oplossing van belangrijke vragen in het domein van gezonde voeding en leefomgeving. Met ongeveer 30 vestigingen, 6.800 medewerkers ( $6.000 \mathrm{fte}$ ) en 12.900 studenten behoort Wageningen University \& Research wereldwijd tot de aansprekende kennisinstellingen binnen haar domein. De integrale benadering van de vraagstukken en de samenwerking tussen verschillende disciplines vormen het hart van de unieke Wageningen aanpak. 